\title{
Communication with Children and Adolescents about the Diagnosis of their own Life Threatening Condition
}

\section{Alan Stein ${ }^{\# *}$, Louise Dalton ${ }^{\#}$, Elizabeth Rapa, Myra Bluebond-Langner, Lucy Hanington, Kim Fredman Stein, Sue Ziebland, Tamsen Rochat, Emily Harrop, Brenda Kelly, Ruth Bland, Communication Expert Group ${ }^{+}$}

\section{Authors}

Prof A Stein FRCPsych. Department of Psychiatry, University of Oxford, Oxford, UK and School of Public Health, Faculty of Health Sciences, University of Witwatersrand, Johannesburg, South Africa *\#

L Dalton DClinPsy. Department of Psychiatry, University of Oxford, Oxford, UK

E Rapa D.Phil. Department of Psychiatry, University of Oxford, Oxford, UK

Prof M Bluebond-Langner PhD. The Louis Dundas Centre for Children's Palliative Care, UCL Great Ormond Street Institute of Child Health, London, UK

L Hanington MRCPCH. Department of Psychiatry, University of Oxford, Oxford, UK

K Fredman Stein MSc. Department of Psychology, University of Bath, Bath, UK

Prof S Ziebland MSc. Nuffield Department of Primary Care Health Sciences, University of Oxford, Oxford, UK

T Rochat PhD. Department of Paediatrics, School of Clinical Medicine, Faculty of Health Sciences, University of Witwatersrand, Johannesburg, South Africa and Human Sciences Research Council, Johannesburg, South Africa

E Harrop PhD. Oxford University Hospitals NHS Foundation Trust, Oxford, UK and Helen \& Douglas House, Oxford, UK

B Kelly FRCOG. Nuffield Department of Women's and Reproductive Health, University of Oxford, Oxford, UK, and Oxford University Hospitals NHS Foundation Trust, Oxford, UK

R Bland MD. School of Public Health, Faculty of Health Sciences, University of Witwatersrand, Johannesburg, South Africa, and Institute of Health and Wellbeing, Glasgow, UK and Royal Hospital for Children, Glasgow, UK

+ Members listed at the end of the paper

\# Joint first author

*Corresponding author: Prof Alan Stein, Department of Psychiatry, University of Oxford, OX3 7JX, UK alan.stein@psych.ox.ac.uk.01865 618190 


\section{Communication with Children and Adolescents about the Diagnosis of their own Life Threatening Condition}

\section{Summary}

When a child is diagnosed with a life threatening condition, one of the most challenging tasks facing healthcare professionals is to communicate this to the child, as well as to their parents or caregivers. Evidence-based guidelines are urgently needed for all healthcare settings, from tertiary referral centres in high income countries to resource limited environments in low and middle income countries, where rates of child mortality are high. We place this narrative review in the context of children's developing understanding of illness and death. We review the impact of communication on children's emotional, behavioural and social functioning, as well as treatment adherence, disease progression and wider family relationships. We consider the factors that influence the process of communication and the preferences of children, families and healthcare professionals about how to convey the diagnosis. Critically, the barriers and challenges to effective communication are explored. Finally, we outline principles for communicating with children, parents and caregivers, generated from a workshop of international experts. 


\section{Communication with Children and Adolescents about the Diagnosis of their own Life Threatening Condition}

Introduction

One of the most daunting challenges for a healthcare professional (HCP) or parent is to tell a child that they have a life-threatening condition (LTC). This is not an uncommon scenario, with millions of children globally living with LTCs. An estimated 1.8 million children are infected with HIV, ${ }^{1}$ and more than 300,000 children develop cancer each year. ${ }^{2}$ In low and middle income countries (LMICs) where the burden of disease is greater, survival rates are often poor. While more than $80 \%$ of children with cancer in high income countries (HICs) now survive for more than five years, the overall survival rates in LMICs are as low as $10 \%{ }^{2}$

Talking to children about their diagnosis matters: it enables them to understand what is happening and improves their cooperation with procedures and adherence to treatment. In the longer term this will empower children and families to advocate for their care and treatment. This is especially important in LMICs, as highlighted by the recent Lancet Commission which found that access to healthcare in this context is often unconscionably low. ${ }^{3}$

The moment that the diagnosis is conveyed is often remembered vividly for many years and signals the beginning of a new trajectory for the family. Within some contexts, mainly in LMICs, HCPs are often faced with LTCs and death, while for others it may be a relatively rare occurrence. Sensitive and developmentally appropriate communication matters enormously to children and their families regardless of their life circumstances. Available recommendations from HICs have considered how to break bad news to parents and adult patients, 4,5 but do not specifically address the delicate task of communicating directly with children about their diagnosis. Without such guidelines this difficult and emotionally challenging responsibility ${ }^{6}$ is sometimes avoided, in part through fear of how the child and their family may react.

Healthcare philosophy about sharing information with children regarding their illness and prognosis has changed significantly over the last 70 years. ${ }^{7}$ Until the 1960 s prevailing practice was to withhold the diagnosis, or its life threatening nature, in the hope that this would protect children from distress. Over subsequent decades the importance of disclosure was increasingly recognised, in part reflecting advances in medical treatment (and thus children's survival) and greater appreciation of children's developmental level of understanding about illness and death. More recently the debate has evolved to a more nuanced and personalised consideration of what, when and how much a child should be told about their diagnosis. Furthermore, acknowledgement that the whole family is affected when a child is unwell has resulted in adoption of family-centred models of paediatric care, which consider the impact of the illness on siblings, parents/caregivers. ${ }^{8}$ The traditional relationship between doctors and patients has also changed, resulting in a shift in the doctor's role to promote patient empowerment and shared decision making. ${ }^{9}$ In resource constrained settings where access to qualified HCPs may be limited, the transferability of these models remains a challenge, particularly in over-burdened health systems.

In seeking to improve communication, HCPs and parents/caregivers alike must be aware of the cognitive, emotional and psychological development of children and adolescents in relation to their understanding of death, as well as the cultural and religious beliefs held by the child and family around 
disease, dying and death. Consideration of these factors will ensure that communication is appropriately tailored to avoid misunderstanding.

Cognitive and emotional developmental stages and conceptualisation of LTC

Consistent with broader Piagetian-based models of cognitive development, children's understanding of illness and death evolves over time, starting with more concrete, clearly defined subcomponents with gradual acquisition of more complex and abstract components (Box 1). ${ }^{10}$

BOX 1: Chronology of acquisition of concepts of death beginning at approximately age 5 years, with full understanding around 10 years.

\begin{tabular}{|l|l|}
\hline Concept & Description \\
\hline Irreversibility & Once the physical body is dead, it cannot be made alive again. \\
\hline $\begin{array}{l}\text { Personal } \\
\text { mortality }\end{array}$ & Death applies to oneself. \\
\hline Universality & All living things must eventually die. \\
\hline $\begin{array}{l}\text { Non } \\
\text { functionality }\end{array}$ & $\begin{array}{l}\text { Once a living thing dies, all life-defining capabilities (such as walking, seeing, thinking) end. } \\
\text { Non corporeal continuation can be considered a separate concept i.e. that there may be } \\
\text { some form of personal continuation after death, such as the soul or spirit, which may be } \\
\text { capable of life-like functions after death such as loving or helping. }\end{array}$ \\
\hline Causality & Realistic understanding of events that might cause death. \\
\hline
\end{tabular}

Children under the age of 2 have an awareness of object permanence and are developing a mental image of a parent/caregiver, becoming distressed when they leave and seek their return. Children aged 3 and 4 understand death as a departure, and part of the natural order of life, but when someone has died it is important for parents/caregivers to repeat the key message that the dead person will not, and cannot return. ${ }^{11}$ It is not typically until the age of 5 or 6 years that children understand the finality and irreversibility of death, ${ }^{10}$ although recent work suggests that some children may acquire this as early as 4 years old. ${ }^{12}$ Other important components include the understanding of personal mortality (that death applies to oneself) around the age of 5 and unpredictability (the time of death is not knowable in advance). By the age of about 9 years, children have a more complete understanding of death.

Children's understanding of what causes illness and death is significantly influenced by what is known as "magical thinking", between the ages of 4 and 7 years. ${ }^{13}$ "Magical thinking" is used to describe children's belief that thoughts, events or wishes can cause external events e.g. that illness can be caused by a particular thought or behaviour. Concurrently children have an emerging sense of conscience, but poor understanding of how illness is spread; this can easily lead to misattribution of cause and consequent guilt (e.g. illness is a punishment for their poor behaviour). ${ }^{11}$ This highlights the importance of ensuring that the language used with children is concrete and specific to avoid misunderstanding or incorrect inferences about the cause of illness or death. ${ }^{11}$

A major shift in children's understanding of key biological concepts about the structure and function of the human body and disease transmission takes place between the ages of 7 and 11 years. ${ }^{13}$ At this stage children also use their emerging reasoning skills more successfully with concrete information rather than abstract concepts, or things that are invisible inside the body. For example, they can 
understand changes related to cancer such as hair or weight loss because these are tangible and observable. However, a fuller understanding of "cancer", chemotherapy or side effects may be more difficult to understand. ${ }^{14}$

Recent advances in understanding brain maturation during adolescence are reflected in a shift towards extending the adolescent age range to 24 years. ${ }^{15} \mathrm{Higher}$ order cognitive processes including executive functions (e.g. inhibitory control, planning and decision making) undergo gradual development during adolescence. ${ }^{16}$ Adolescents' focus on short term consequences is particularly relevant for their decision-making about treatment and may contribute to tension between the different priorities of patients and HCPs e.g. an adolescent's desire for independence and the HCP's focus on a timely treatment regimen. ${ }^{17}$ There is a substantial increase in the salience and influence of peers; establishing and maintaining peer group identification is complicated by social isolation due to periods of inpatient treatment, or feeling or looking different due to their LTC. Adolescence also involves establishing autonomy from parents/caregivers, which may conflict with periods of increased dependency during treatment. The incidence of depression and anxiety peaks during adolescence, making this a time of increased vulnerability. ${ }^{18}$ Recognition of the specific developmental challenges of LTCs during adolescence is reflected in service innovations for adolescents and young adults with cancer in $\mathrm{HICs} .{ }^{19}$

Developmental models rarely consider the potential influence of children's prior experiences and exposure to illness and death on their understanding of these concepts. A number of case reports ${ }^{20}$ and anthropological studies ${ }^{21}$ suggest young children (age 5-7 years) can be aware of their impending death. Empirical studies indicate that children who have had greater experience of death (through living in areas where illness or armed conflict are endemic) have a relatively advanced understanding of death, ${ }^{22,23}$ although the evidence is limited and inconsistent. ${ }^{24,25}$

In the emotional turmoil of distressing news, children may function as if they had a less developed understanding of death than their chronological age might suggest. ${ }^{11}$ The specific needs of children with cognitive or sensory disabilities must also be considered. Whilst these children are more likely to suffer significant ill health, their communication needs are often poorly met in healthcare settings ${ }^{26}$ which may adversely affect their outcomes. ${ }^{27}$ National Institute for Health and Care Excellence (NICE) guidance recommends that for all children with life limiting illness, information delivery should take into account both their age and level of understanding. ${ }^{28}$

\section{Cultural understanding of death}

Culture and traditions, ethnicity, religious and spiritual beliefs will also influence children's and parents'/caregivers' perspectives on the meaning of death and illness e.g. possible reluctance in Catholic communities to disclose LTC because it could preclude hope and faith. ${ }^{29}$ Conceptual understandings of death vary widely across the globe e.g. a study in South Africa described how death can be seen as a transformational experience in which communication remains possible with deceased family members. ${ }^{30}$ The way these factors interact requires HCPs to explore an individual's belief system to ensure the information communicated is meaningful, and enable the HCP to avoid stereotypes and recognise the different cultural and religious reference points of family members. ${ }^{31}$

\section{Aim of the review}


Given the scale of the global burden of LTCs involving children, and the absence of evidence-based guidelines to support HCPs and families to communicate the diagnosis, the available literature was interrogated with the aim of addressing three main questions:

1a) What is the impact of communication about a LTC on children and adolescents' emotional, behavioural and social outcomes; illness related factors including adherence to treatment, disease transmission and progression? 1b) What is the impact of the communication on their parents/caregivers and the wider family system?

2) What factors influence the process of communication and what are the barriers and challenges to communication?

3) What are the reported preferences of children, adolescents and parents/caregivers about the way diagnostic information is conveyed?

The outcomes of the narrative review and previously published recommendation $\mathrm{s}^{5,32}$ formed the basis of discussion at a workshop of international experts in 2017 to generate a framework of communication principles.

\section{Methods (see appendix)}

\section{Results}

\section{Findings of the Review}

The results of the narrative review are presented in relation to our three research questions; details of each study in the review are summarised in Table 1 (appendix). The varied literature has disproportionately focused on the experience of families and children with cancer in HICs, and HIV in LMICs.

Although rarely a primary question of research studies, there is wide variation in whether children are told about their diagnosis, and how to do it. Research from Italy exploring parental communication with their children ( $n=64 ; 4-18 y r s$ ) who had cancer suggests that nearly $20 \%$ of parents $(n=64)$ did not talk to their children about the disease ${ }^{33}$, and $64 \%$ of parents $(n=86)$ in the Netherlands did not discuss impending death with their child (1-17yrs). ${ }^{34}$ Non-disclosure rates to children infected with HIV are high, with a recent systematic review of 22 articles representing 12 LMICs indicating the proportion of children who received full disclosure ranged from $1.7 \%$ to $41 \% .{ }^{35} \mathrm{~A}$ review of 31 studies describing patterns of HIV disclosure found that the proportion of children who knew their status was lower in LMICs (median 20.4\%) than 'industrialised countries' (mostly USA) (43\%). ${ }^{36}$ There may also be discrepancies between caregivers' beliefs about the importance of disclosing a diagnosis of HIV and their own disclosure practice. A survey of caregivers $(n=271)$ of HIV infected children (6-16yrs) in Kenya found that $79 \%$ of carers believed children should know their HIV status, although only $19 \%$ had disclosed to their children. ${ }^{37}$ This highlights the importance of identifying the barriers which impede communication.

Following the early work of Bluebond-Langner ${ }^{38}$, studies exploring children's views consistently report the importance of honest discussions about illness, prognosis and death. A survey of adolescents ( $n=17 ; 14-21 y r s$ ) with cancer in the USA found $75 \%$ indicated a preference for end-of-life discussions 
not only "if dying" but at an early stage of the disease. ${ }^{39} \mathrm{~A}$ qualitative study in the Democratic Republic of Congo (DRC) ( $n=19 ; 10-21 \mathrm{yrs}$ ) explored the experiences and reactions of children to disclosure of their HIV status; although some reacted with surprise, sadness and worry, many felt relieved to have an explanation for their illness and most reported that it was better to know their diagnosis. ${ }^{40}$

1a) What is the impact of communication about a LTC on children and adolescents' emotional, behavioural and social outcomes; illness related factors including adherence to treatment, disease transmission and progression

\section{Emotional, behavioural and social outcomes}

Studies have identified benefits of communication for children and adolescents across a range of outcomes, although this is not universal. In the oncology literature a Dutch study of children with cancer ( $n=56 ; 8-16 y r s$ ) who received earlier information about their diagnosis and prognosis reported fewer symptoms of anxiety and depression compared to children who received less information or information at a later stage. ${ }^{41} \mathrm{An}$ Italian mixed methods study of communication between children treated for a brain tumour and their parents systematically classified parents' communication against a number of key objectives (such as the completeness and consistency of information given). ${ }^{33}$ Psychological indicators of distress, including withdrawal, anxiety/depression and social problems, were significantly more infrequent when communication was classified as effective, as compared to avoidant or ineffective. ${ }^{33}$ Retrospective reports from parents $(n=86)$ whose children ( $\left.n=56 ; 1-17 y r s\right)$ had died from cancer 3-8 years previously identified reducing their child's fear as one of the benefits of talking to their child about death. ${ }^{34}$

Several studies have explored the impact of the disclosure of an HIV diagnosis on children's psychological wellbeing. A quantitative study in the USA of children ( $n=196 ; 8-16 y r s)$ with perinatally acquired HIV and their carers $(n=196)$ found lower levels of anxiety in children who knew their HIVpositive status. ${ }^{42}$ HIV-positive adolescents ( $n=127 ; 11-15 y$ rs) in Zambia whose HIV status had not been disclosed reported significantly higher levels of emotional difficulties than those who knew their diagnosis. ${ }^{43}$ Delayed disclosure may have a negative impact, with children reporting feelings of anger and betrayal that they had not been told earlier. ${ }^{44,45}$ HCPs in a South African study reported early disclosure reduced children's sense of being deceived. ${ }^{46}$ Other studies have shown neither significant benefits, nor adverse effects of disclosure, for child or family-relationship outcomes. ${ }^{47}$

Children ( $n=77 ; 3-13 y r s)$ may experience a range of emotions at the time of disclosure about their diagnosis including shock, sadness, anger, worry and confusion, although these negative emotions do not always persist. ${ }^{47}$ A group of children in Puerto Rico ( $n=40$; mean age $13.8 \mathrm{yrs}$ ), reported very low rates (5\% or less) of sadness, depression and worry 6 months after disclosure of their HIV status and $70 \%$ described feelings of "normalcy". ${ }^{48}$

A prospective, observational study of the psychosocial impact of a paediatric HIV disclosure programme in Thailand ( $n=160 ; 7-18 y r s$ ) showed improved social functioning at 6 months follow-up, in addition to a small but significant decrease in depressive symptoms. ${ }^{49}$ Improved communication may alleviate uncertainty and consequently improve quality of life. Greater uncertainty about the illness and treatment in children $(n=120 ; 8-18 y r s)$ receiving cancer treatment was associated with poorer overall health-related and cancer-related quality of life (after controlling for age, anxiety and pain)..$^{50}$ 
Children with LTCs can have painful investigations and lengthy treatment regimens with unpleasant side effects. Communication between the child, their parents/caregivers and HCPs helps to gain the trust of the child and is associated with enhanced adherence through improved understanding of illness and the importance of treatment. ${ }^{51,52}$ A study in South Africa of adolescents ( $\left.n=684 ; 10-19 y r s\right)$ with HIV found that knowledge of HIV status doubled the odds of self-reported full adherence to their drug regimen. ${ }^{46}$ Similarly, a prospective cohort study in Zambia ( $n=96$; median 6yrs) found that compared to those who knew their HIV status, children who did not know had poorer antiretroviral therapy (ART) adherence..$^{53}$ Improved medication adherence is consistently cited as a benefit of HIV status disclosure from several qualitative studies from the DRC, Uganda and Nigeria. ${ }^{54-56}$ Children have even reported refusing medication as a strategy to obtain additional information if caregivers were reluctant to explain the purpose of the treatment. ${ }^{45}$

Children's understanding and awareness of an HIV diagnosis potentially reduces risky behaviours which can lead to the transmission of HIV. Research in Brazil ( $n=36$; 1 -15yrs) found that HIV-positive adolescents had little communication about their diagnosis, resulting in a poor understanding of the risks of unprotected sex or donating blood. ${ }^{57} \mathrm{~A}$ qualitative study in the DRC ( $n=8 ; 8-17 y$ rs) reported that children viewed the ability to protect others from infection as an important advantage of knowing their diagnosis. ${ }^{58}$ In a study in the USA ( $\mathrm{n}=196$ caregivers and children) children and adolescents (8$16 y$ rs) who had been aware of their HIV status for longer reported greater intention to disclose their status to sexual partners. ${ }^{42}$ Disclosure may actually prevent risky sexual behaviour as HIV-positive adolescents who were aware of their status were more likely to consistently use condoms than unaffected peers. ${ }^{59}$

A child's knowledge of their HIV status may have implications for the progression of their disease. A retrospective database analysis in Romania ( $n=325 ; 5-17 y r s)$ found that children who did not know their HIV diagnosis were more likely to have compromised immune function as measured by reduced CD4 counts, or even die. ${ }^{60}$ Evidence from the USA suggests that children ( $n=64 ; 8-18 y r s$ ) who had recently disclosed their HIV status to friends had improved CD4 counts over subsequent months (but no changes in either self-concept or behavioural problems). ${ }^{61}$

1b) What is the impact of the communication on their parents/caregivers and the wider family system?

Evaluation of a disclosure model for paediatric patients with HIV ( $n=40$; mean age 13.8yrs) in Puerto Rico found the disclosure process helped a significant proportion of children and adolescents feel more supported by parents (57\%), grandparents (48\%) and clinic staff (48\%). ${ }^{48}$ Indeed, $85 \%$ of the participants considered disclosure as a positive event for them and their families. Caregivers' comments reflected a sense of relief at no longer lying or continuing to hide a secret from their children. ${ }^{48}$

The relationship between communication and outcomes for parents/caregivers has also been explored. A retrospective Swedish survey of bereaved parents $(n=449)$ whose children had died from cancer at least 4 years previously found that of the 147 parents who had talked to their child about death (a third of all participants), none regretted it. ${ }^{62}$ Of the parents who had not talked to their 
children $27 \%$ said they regretted their decision, and there were higher levels of current parental anxiety and depression within this sub-group. ${ }^{62}$

A study of the communication between HCPs and parents of children with cancer ( $n=304)$ in Egypt demonstrated significant relationships between parents' satisfaction with the doctor's communication style and trust in their child's physician. ${ }^{63}$ Furthermore, trust was key to improvements in patient adherence and a more positive view of the future. ${ }^{63} \mathrm{~A}$ US retrospective study of parents ( $n=103$ ) whose children had died from cancer (mean age 10 years at death), found that a shared acknowledgement between HCPs and parents of the seriousness of the prognosis was associated with better quality of care at home (parent-rated) and earlier consideration of hospice provision. ${ }^{64}$

\section{What factors influence the process of communication and what are the barriers and challenges to communication?}

The process of communication with a child around major illness is dynamic, influenced by a number of factors within the triad of patient (child/adolescent), parent/caregiver and HCP relationships which may either facilitate communication or create barriers (figure 1). These factors can evolve over time with changes in knowledge of the condition, disease progression and developmental understanding.

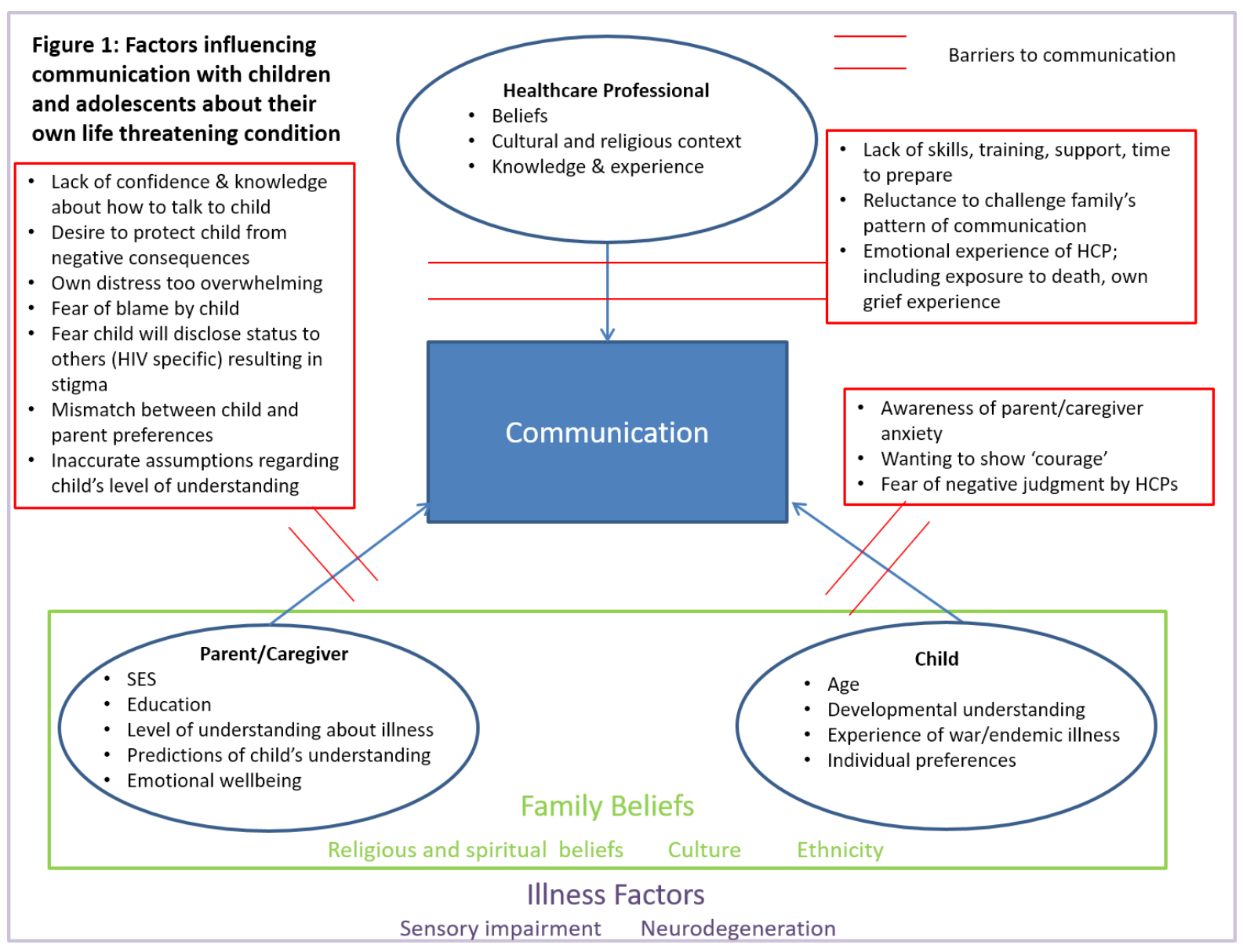




\section{Child Factors}

While many children and adolescents want information about their illness, including discussions as to whether they may die, this is not universal, with estimates of one third to one quarter of adolescents not wanting this information. ${ }^{39,41,65}$ In a US mixed methods study of survivors ( $n=52 ; 7-21 \mathrm{yrs}$ ) of childhood cancer, some "well-adjusted" survivors had "embraced their cancer" and become experts and advocates, whereas others had "encapsulated the illness" and "acknowledged it as little as possible" ${ }^{66}$ Some survivors of childhood cancer reported that their own lack of understanding and awareness of their illness at the time had helped them to cope. ${ }^{66}$

A retrospective study of bereaved parents $(n=86)$ found that of those $(n=55)$ that did not talk to their children (1-17yrs; median age 7 years) about death, some had based their decision on the perception that their child did not wish to discuss their own death. ${ }^{34}$ Children ( $\left.n=38 ; 4-19 y r s\right)$ may be unwilling to talk, or feel inhibited about raising their concerns ${ }^{67}$, particularly if they are aware of their parents' anxiety and discomfort around the subject. ${ }^{68}$ Wanting to show courage and fear of negative judgement from HCPs can also inhibit children's communication. ${ }^{67}$

\section{Child Demographic Factors}

Parents and caregivers in a number of studies from HICs and LMICs highlighted a concern that their child was too young to understand their diagnosis, ${ }^{34,56,69-71}$ and that more information is shared with older children, ${ }^{33,59,62,72,73}$ with systematics reviews of paediatric HIV disclosure concluding that children between the ages of 10 and 15 years are usually told their HIV status. ${ }^{59} \mathrm{~A}$ quantitative study from the DRC ( $n=201 ; 5-17 y r s)$ reported sexual debut as a trigger for caregivers to disclose adolescents' HIV status to them. ${ }^{74}$ However, it is important to differentiate between the quantity of information shared and the effectiveness of communication. Analysis of the communication between parents and children ( $n=64 ; 4-18 y r s)$ surviving a brain tumour found communication varied with the child's age. ${ }^{33}$ 'Avoidance of communication' was most frequent with the youngest children, whereas ineffective communication was more frequent with the older age groups. Parents may underestimate younger children's understanding, which leads to information being omitted. Conversely, parents may overestimate older children's understanding and provide too much detail or at too complex a level. ${ }^{33}$

School attendance, child's educational level, children on ART, urban versus rural residence, having a caregiver who has self-disclosed their own HIV positive status, religious and spiritual beliefs have all been explored in relation to HIV disclosure. ${ }^{59} \mathrm{~A}$ study of perinatally affected children ( $\left.n=77 ; 3-13 y r s\right)$ living in the USA found no association between child knowledge of HIV and gender, ethnicity, caregiver education, parent/caregiver-child relationship factors, adoptive versus biological placement or other health status indicators; this study was conducted in the pre-ART era. ${ }^{47}$

\section{Parental/caregiver factors}

Parents/caregivers are often the interface between HCPs and the child or adolescent. Parents may adopt (or be delegated) a range of different roles $^{71,72}$ in the communication triad ${ }^{75,76}$ which are dependent on a number of factors (Box 2). 


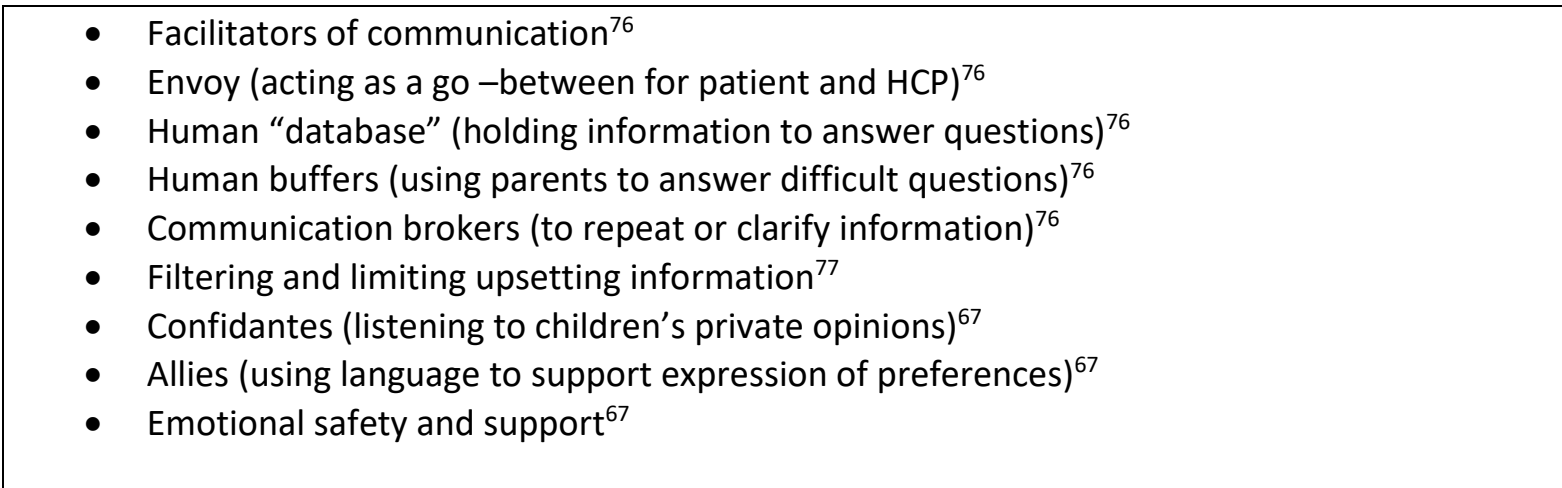

Understanding, beliefs and the response to information about a child's LTC

Parental communication is linked to parents' own understanding and emotional response to the diagnosis. A study of UK-based parents $(n=55)$ of children (3-18yrs) diagnosed with leukaemia explored the impact of parental perception of illness on the information they subsequently communicated to their children. ${ }^{72}$ Parents who believed the diagnosis was incurable and would result in death were less likely to inform their child that the diagnosis was cancer and gave as little information as possible. In contrast, parents who described themselves as too shocked and unable to grasp the information were more likely to tell their child as much as they understood, including the cancer diagnosis. ${ }^{72}$ Thus high levels of parental shock can lead to potential miscommunication or misinterpretation of information, which in turn is passed on to their child. Parents' decisions not to talk to their child may also reflect their own emotional distress and a desire to protect themselves from the "unbearable" reality of the situation. ${ }^{68}$

Parents may struggle to anticipate or react to worries their child may have. Parents frequently reported lacking confidence in their ability to answer difficult questions, particularly those about death. ${ }^{34,56,69-71}$ A qualitative study in the DRC found that caregivers $(n=8)$ were sometimes unaware that their children ( $n=8 ; 8-17 y r s)$ had outstanding questions or concerns after HIV disclosure. ${ }^{58}$

There is variation in parental beliefs about talking to children about LTCs. A study of bereaved parents found that while those who talked to their child about death did not regret it, over $70 \%$ of those who had chosen not to tell their child did not regret their decision. ${ }^{62} \mathrm{~A}$ Dutch study of parents $(n=86)$ whose child had died 3-8 years previously, reported that 36\% did discuss their child's impending death with them, of whom $80 \%$ reflected positively. Of those who did not talk about death with their child, $60 \%$ reflected positively. The authors conclude that parents need support making this decision. ${ }^{34}$

\section{Parental/caregiver education and sociodemographic background}

Parental/caregiver educational level can influence communication, although the literature is inconsistent. A cross sectional study of caregiver-child dyads in Ethiopia ( $n=390 ; 1-14 y r s)$ found higher rates of disclosure among caregivers who were illiterate compared to caregivers with a higher educational level. ${ }^{78} A$ similar finding was noted in a Thai study of caregivers $(n=103)$ of HIV infected children (6-16yrs). ${ }^{79}$ Conversely a study in the USA found that children who knew their HIV status were more likely to come from families with a higher socioeconomic status. ${ }^{80}$ 
Parents/caregivers may not appreciate the potential importance of communication ${ }^{68}$ and frequently express a desire to "protect their child" fearing that disclosure will have negative psychological consequences for their child including distress, depression, anxiety, isolation and loss of hope..$^{34,56,70,71,79}$ Other parents reported that they did not want to challenge their own, or their child's hopes that the illness might be cured..$^{34}$ For some parents, death was not seen as an appropriate topic to talk about with children. ${ }^{34}$

Parents/caregivers of children with HIV sometimes feared that disclosure would prompt children to ask difficult questions about the source of HIV, and blame, resent or lose respect for their parent. ${ }^{56,70}$ The stigma associated with an HIV-positive status can create concern for parents/caregivers that the child will disclose their status to others, with negative consequences not only for the child, but the whole family. ${ }^{36,56,70}$ Similar sentiments were not reported in the literature pertaining to cancer.

\section{Parental emotional wellbeing}

Parental mental health may also influence communication. A cross sectional study of children with cancer and their mothers in the USA ( $n=94 ; 5-18 y r s)$ found mothers' symptoms of depression were associated with their observed communication style (e.g. maintaining the same topic as the child, maternal reflections on children's contributions to the illness-related discussion). ${ }^{81}$ Mothers with more symptoms of depression were rated by observers as having a more negative communication style and were less warm, supportive and responsive when interacting with their child. ${ }^{81}$

\section{Factors influencing HCPs' communication}

The HCPs' contribution to the triad of communication (child, parent/caregiver and HCP) is also influenced by their own beliefs, cultural and religious context, experience and knowledge, both at a professional and also personal level (figure 1). Barriers reported by HCPs include a lack of skills, training and time to prepare for discussions and reluctance to challenge a family's "avoidant pattern of communication". ${ }^{68,82}$ The paediatric oncology literature identified barriers including "a lack of provider knowledge, experience or comfort; clinical uncertainty; a lack of patient/parent comfort or readiness; unrealistic parental expectations; and a lack of cultural support". ${ }^{83}$ There are specific stressors associated with working with patients who are seriously ill which may impact on HCP's ability to communicate effectively with their patients and include: frequent exposure to death; a lack of time to spend with dying patients; a growing workload and large numbers of deaths; coping with one's own emotional response to dying patients; the need to carry on "as usual" in the wake of patient deaths; communication difficulties with dying patients and relatives; identification with, or developing friendships with patients; an inability to live up to one's own standards (e.g. internalised responsibility to provide a "good death") and feelings of depression, grief and guilt in response to loss. ${ }^{84}$ Frequent exposure to death may activate HCP's own memories of unresolved loss. ${ }^{85} \mathrm{HCPs}$ can feel helpless that they were not able to prevent a child's death or spare the family emotional anguish..$^{85}$ The emotional impact of these issues can lead HCPs to feel ill-equipped to support children and their parents/caregivers, and could contribute to the high levels of psychological morbidity reported in UK clinicians (40\% in 2002) and medical students. ${ }^{86} \mathrm{HCP}$ 's strategies to manage their painful feelings in response to these challenging situations may include creating a physical or emotional distance 
between themselves and the family through busyness, impatience or formality, which can further impede communication. ${ }^{87,88}$

Conversely, there is some evidence that HCPs involved in palliative care have comparable levels of stress and "burnout" relative to colleagues in other specialities. ${ }^{84}$ This may reflect service related factors within palliative care, such as high quality staff support which mitigate some of the stressors associated with working with dying patients. ${ }^{84,89}$ This indicates support structures are key for HCPs dealing with LTCS in different healthcare contexts, but may only be aspirational in resourceconstrained settings.

\section{Differences in views, needs and preferences within the triad}

HCPs and parents $(n=38)$ may have very different views about how much information should be shared with the child, often originating from parents' desire to "protect" their child ( $n=16 ; 13-19 y$ rs at time of diagnosis). ${ }^{17}$ Although HCPs may advocate an "open and honest" approach to disclosure and information sharing, parents may disagree ${ }^{77}$ particularly around perinatally acquired HIV. ${ }^{90,91}$ Accurate information supports congruence between a child's internal world (i.e. awareness of their illness, changes in their body, people's reactions and possibly their imminent death) and their outer world (i.e. information from parents and HCPs). ${ }^{62}$ There can be a mismatch between parents' and children's preferences for communication. ${ }^{75}$ If the child is absent or excluded their knowledge and understanding of the illness is likely to be determined by the parent. Studies highlight that children may learn about their disease and how serious it is without being explicitly told. ${ }^{21,92}$ The parent and child may each attempt to protect the other from their own awareness of the disease by not acknowledging it. This 'mutual pretence" ${ }^{7}$ may have negative consequences if the child feels alone in making sense of frightening knowledge without any support to manage the emotional consequences. ${ }^{87}$ Some families' usual style and coping mechanism is not to communicate; while this needs to be respected it should not be assumed that the child does not want information, and the possibility of discussing the child's diagnosis should be re-visited. Increasing autonomy during adolescence can also result in parents/caregivers and adolescents holding contrasting views about treatment decisions. These situations are both ethically and emotionally challenging for HCPs, especially if the HCP has a strong opinion themselves. ${ }^{17}$

\section{What are the preferences of children, adolescents and parents/caregivers about the way diagnosis and information is conveyed?}

Studies have investigated the preferences of parents/caregivers and children regarding what and how diagnostic information is communicated (Box 3 ). The majority of participants were adolescents with cancer, predominantly from HICs, but their views offer invaluable practical guidance for HCPs which may be applicable across multiple healthcare settings. 
BOX 3: The preferences of children, adolescents and parents/caregivers about the way diagnosis and information is conveyed

Preferences about how information is communicated

1. Relationship with HCP: Trust, honesty and empathy of HCPs highlighted by qualitative studies of children, adolescents and parents (child and adolescent patients ${ }^{17,93,94}$, parents ${ }^{93,95}$ )

a. Adolescents valued a professional-friendly relationship in which they felt the HCP was genuinely concerned and interested in them as an individual, rather than a collection of symptoms ${ }^{93}$

b. Respect within the relationship (adolescent report)

i. Demonstrated through the way staff recognise and negotiate an adolescent's priorities and competing demands (e.g. maintaining social relationships around treatment) ${ }^{17}$

ii. Communicated through sensitivity to cues that adolescents may not want to talk at a particular moment ${ }^{67}$

iii. Large ward rounds feel an invasion of privacy for adolescents; preference for separate discussions ${ }^{94}$

c. Respect within the relationship (parental report)

i. Facilitated by the doctor looking at them, greeting and addressing them by name ${ }^{95}$

ii. Demonstrated through recognising their parental role and being acknowledged as the experts about their child ${ }^{93}$

iii. Honesty extends to explicitly acknowledging the limits of professionals' knowledge ${ }^{93}$

iv. Importance of empathy, particularly in situations of poor prognosis, when parents have limited experience of serious illness, or conversely, when parents work in healthcare and consequently hold substantial knowledge ${ }^{73}$

2. Language:

a. Direct, clear and as simple as possible $e^{73,94}$

b. Tailored to their particular age group (rather than "one size fits all")

c. Balance between being understandable but not overly simple or "baby-ish"67,93

d. Avoid technical jargon; experienced by adolescents as an attempt to keep them powerless $^{94}$

e. Straightforward approach particularly around sensitive topics such as side effects, prognosis and fertility (sperm banking ${ }^{94} /$ oocyte preservation)

3. Adequate time for consultation:

a. Enables information to be paced, questions answered and clarification sought on both sides $^{17,73,94}$

b. Parents, children and adolescents recognise the impact of the initial shock of diagnosis; want time in order to come to terms with upsetting information ${ }^{93}$

c. Opportunity to ask questions; staff need to recognise that this is not always straightforward for children and adolescents, so they may need help to do so ${ }^{67}$

d. Information about the timing of meetings to discuss their care; this was prompted by a desire not to get up too early (adolescents) or to ensure adequate preparation and attendance (parents) ${ }^{93}$

e. Some adolescents wanted discussions with HCPs without their parents present ${ }^{94} 96$

4. Continuity of care:

a. Preference for consultations being with same HCP (where possible) throughout treatment (adolescents and parents) ${ }^{93}$

b. Consistency in the language and terms used ${ }^{93}$ 


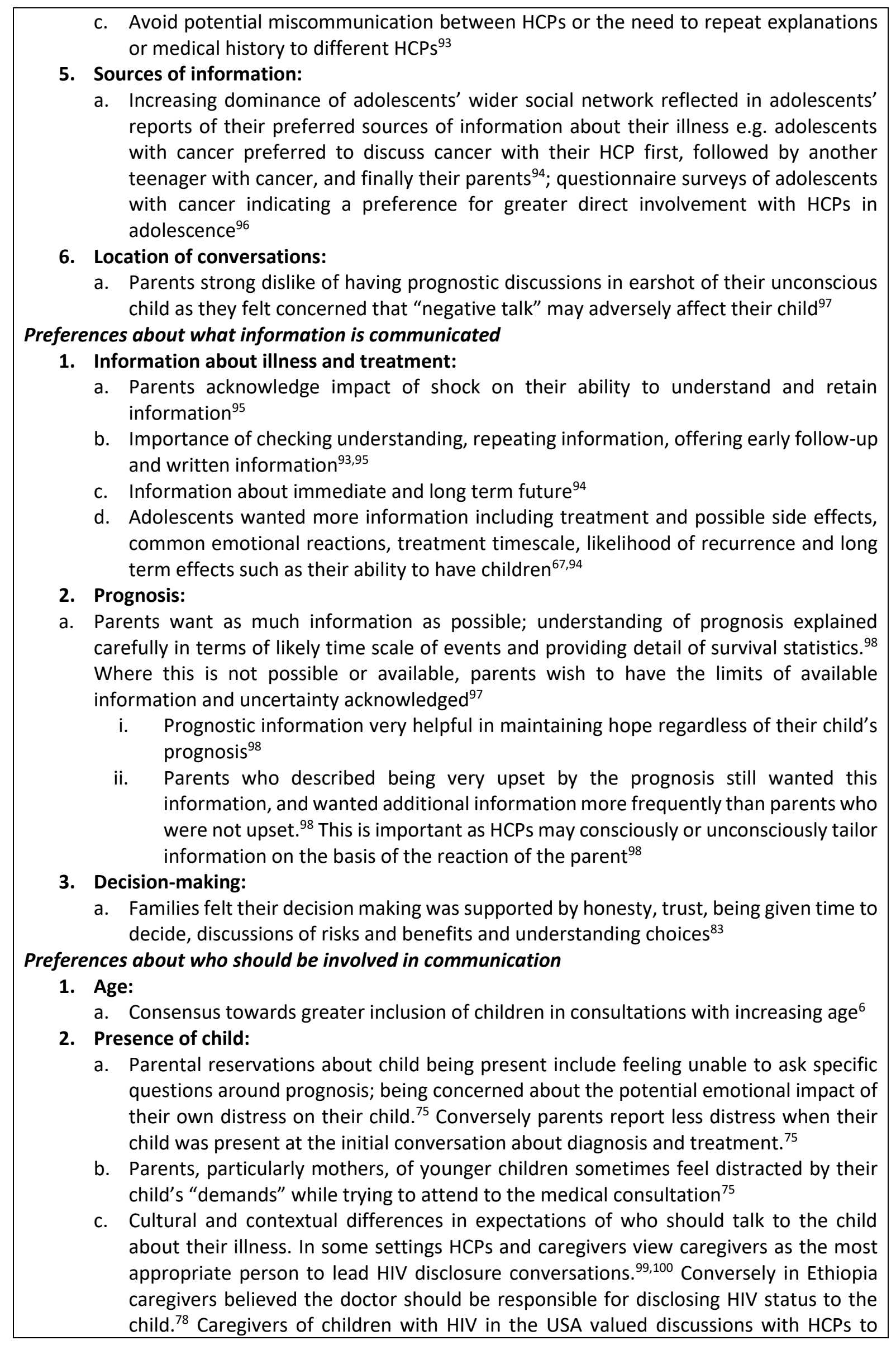




prepare for conversations with their child about the diagnosis and often cited the HCP
as the most appropriate person to talk to their child. ${ }^{101}$ A South African study found
parental/caregiver discussion about disclosure with a HCP was associated with
disclosure to the child; $96 \%$ of parents/caregivers who had not discussed disclosure
with a HCP reported that they would like to talk to a HCP about disclosure. ${ }^{102}$

\section{Ethical perspectives}

Ethical and moral arguments are pertinent to communication with children with LTCs. In the UK, the NICE guidelines recommend that children can be active stakeholders in all aspects of advance care planning. ${ }^{28}$ Paediatric cancer patients are frequently enrolled into clinical trials and an ethical case is often made for communication as it facilitates the process of obtaining assent/consent for participation in trials and promotes the emerging autonomy of the child. ${ }^{103} \mathrm{It}$ is important to respect young people's wishes regarding what information they do and do not want ${ }^{77}$ and to take account of their developmental capacities whilst upholding the principles of the UN Convention on the Rights of the Child. ${ }^{104}$

\section{Expert Group Workshop and Development of Framework}

The expert group of clinicians and researchers with extensive experience of working with children and families affected by LTCs in HICs and LMICs met for a two day workshop in Oxford, UK in 2017. The group used the outcome of the literature review, previously published recommendations ${ }^{5,32}$ and integrated these with their academic and clinical perspectives. This iterative process resulted in a framework of principles to facilitate HCPs in communicating with families (Box 4). These are guiding principles; it is not expected that every principle applies to every situation and each HCP should also use their clinical skill and judgement for each family, recognising cultural differences that influence what is considered appropriate to discuss with children. It is important to be aware of the circumstances e.g. in an acute situation the child and parent/caregiver may be unable to assimilate large quantities of information (due to physical symptoms such as fatigue or pain, as well as emotional distress). Key messages must be prioritised, repeated and understanding checked.

\section{Limitations and Future Directions for Research}

Despite the potential benefits of effective communication, many children are not told about their diagnosis. The global prevalence of LTCS in children makes it an urgent priority to develop robust, child-focused communication guidelines and a research agenda to address the limitations and gaps in the literature.

Limitations of the research literature include the wide age range of participants and stage of the illness. Some work has explored these issues by actively recruiting participants at specific points on their treatment journey. ${ }^{41}$ The reviewed qualitative studies are dominated by interview accounts; analyses of recorded consultations are rare, but could advance our understanding. A proportion of studies do not have relevant control/comparison groups which makes evaluating the impact of communication difficult to determine. There is almost a complete lack of adequately powered, controlled evaluation studies, especially randomised controlled trials (including pragmatic trials), to evaluate interventions or best practice. 
Openness is a consistently recurring theme within the literature, but is usually poorly defined or quantified with an implicit assumption that it relates to an explicit and honest exchange of information between the child and parent/caregiver or HCP. Moreover, the informational or emotional content and developmental appropriateness of the communication is rarely specified or evaluated. This should be addressed in future research.

It may be perceived as difficult to initiate research at such a vulnerable time in a family's life, with ethics committees and staff (understandably) protective of this patient group. However, research with recently bereaved parents $(n=69)$ indicated that while many were initially motivated by altruistic reasons to take part in research, participants subsequently reflected that they had found it personally helpful. ${ }^{105}$ We should therefore consider how to sensitively involve children and parents/caregivers in research closer to the moment of diagnosis.

Most research is restricted to cancer (in HICs) and HIV (predominantly in LMICs) which does not reflect the global prevalence of LTCs, or children with acute LTCs. Globally, most children live in LMICs and more research must be devoted to their healthcare needs, as well as the ever expanding situations of violence, war, poverty and the effects of climate change. Addressing the needs of younger children and those with disabilities in both HICS and LMICs needs to be an important priority. ${ }^{28}$ This review is limited to consideration of the ill child, but their condition is likely to impact on children in the extended family, particularly siblings who may have differing developmental needs. The framework of principles (box 4) is could be useful for siblings, but further work is required. Parents'/caregivers' and children's increasing ability to access information independently through the internet creates both opportunities and challenges which impact on the communication relationship with HCPs. Communication skills are a key component of training curricula for HCPs, but the impact of such training on clinical practice has rarely been evaluated, ${ }^{4}$ or the barriers which impede implementation. ${ }^{4}$ More extensive communication skills training and ongoing support programme are required in both LMICS and HICs.

Communicating the diagnosis of LTC to a child is not a single event and evolves over time and illness trajectory, including supportive discussions about management and prognosis. However, the moment of diagnosis serves as the foundation for a longer term communicative relationship between the HCP, parents/caregivers and child. ${ }^{106}$ Effective communication requires an understanding of how the parent/caregiver and child perceive the situation, the transfer of factual information and also emotional scaffolding for parents, caregivers and families. Providing emotional support to families is time consuming and undoubtedly has an impact on HCPs; support to process the personal impact of this work is crucial to ensure HCPs are able to cope with the emotional demands of this work. 
BOX 4: Principles to assist health-care professionals in communicating with children, adolescents and parents about life-threatening conditions before, during and after consultation

\begin{tabular}{|c|c|c|c|}
\hline Principle & Detail & Challenges & Suggested Phrases \\
\hline Prepare yourself & $\begin{array}{l}\text { Examine your own comfort levels and beliefs. } \\
\text { Use of supervision/ consultation as well as peer support } \\
\text { can be invaluable. } \\
\text { Ensure that when you meet the child, they can see you as } \\
\text { a calm and focused person who is able to hear and tolerate } \\
\text { their distress and provide emotional support. }\end{array}$ & $\begin{array}{l}\text { Time limitations due to } \\
\text { pressure of work. } \\
\text { Managing your own } \\
\text { distress about talking to } \\
\text { the child about their } \\
\text { illness. } \\
\text { Managing your own } \\
\text { experience of } \\
\text { bereavement or loss. }\end{array}$ & \\
\hline $\begin{array}{l}\text { Prepare } \\
\text { information }\end{array}$ & $\begin{array}{l}\text { Plan what you need to communicate; prioritise key } \\
\text { information. } \\
\text { Check you know the name of the child and members of the } \\
\text { family. Check relationships between the child and family } \\
\text { (e.g. step parents). }\end{array}$ & $\begin{array}{l}\text { Missing or inadequate } \\
\text { information in child's } \\
\text { health record. }\end{array}$ & $\begin{array}{l}\text { "Is there anyone else } \\
\text { who is important to you, } \\
\text { who could be here to } \\
\text { support you?" } \\
\text { "My name is insert your } \\
\text { name, can I just check I } \\
\text { know everyone's name } \\
\text { and who is here today?" }\end{array}$ \\
\hline $\begin{array}{l}\text { Prepare } \\
\text { environment }\end{array}$ & $\begin{array}{l}\text { Identify a quiet and private area. } \\
\text { Consider who is with the child and who should be included } \\
\text { in consultation, including relatives, advocates or other } \\
\text { health-care professionals well known to child or family. } \\
\text { Make arrangements to care for other siblings as } \\
\text { appropriate, or if they are to be present, consider their } \\
\text { needs (e.g. organising toys, colouring). }\end{array}$ & $\begin{array}{l}\text { Availability of childcare } \\
\text { for siblings to best } \\
\text { support those taking } \\
\text { part in conversation. }\end{array}$ & $\begin{array}{l}\text { "Would it help if we } \\
\text { found someone to look } \\
\text { after your younger } \\
\text { children while we talk?" }\end{array}$ \\
\hline
\end{tabular}




\begin{tabular}{|c|c|c|c|}
\hline Development & $\begin{array}{l}\text { Check the age of the child and any known } \\
\text { neurodevelopmental problems or communication } \\
\text { impairments. } \\
\text { Consider child's understanding of language to be used in } \\
\text { consultation (find interpreter if appropriate). } \\
\text { Consider child's likely developmental understanding. } \\
\text { Consider how to make information relevant to child's } \\
\text { everyday context and culture. } \\
\text { Choose developmentally appropriate language; accessible } \\
\text { but not patronising. } \\
\text { Consider use of universal communication tools - i.e. } \\
\text { picture charts and things such as faces/symbols to gauge } \\
\text { happy/sad/good/bad etc. }\end{array}$ & 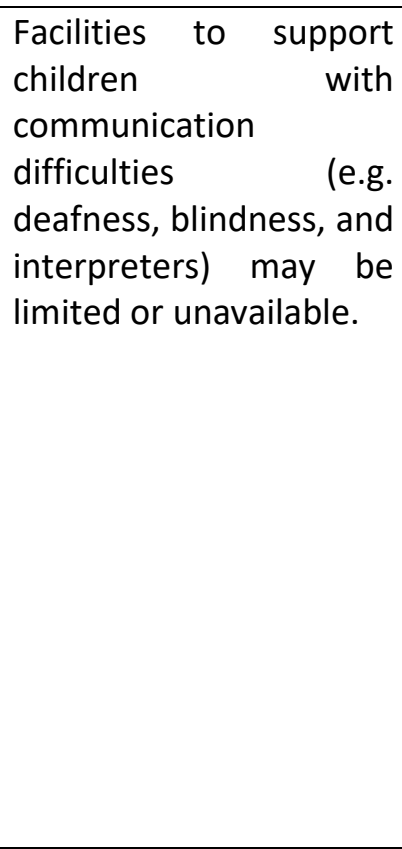 & $\begin{array}{l}\text { "How much do you feel } \\
\text { your child understands } \\
\text { about the world around } \\
\text { them and about their } \\
\text { condition/care?" } \\
\text { "Are there any tools you } \\
\text { use in communicating } \\
\text { with your child that we } \\
\text { could make use of in this } \\
\text { conversation?" }\end{array}$ \\
\hline $\begin{array}{l}\text { Prepare the } \\
\text { parents }\end{array}$ & $\begin{array}{l}\text { Discuss with parents the importance of communicating } \\
\text { with the child about the diagnosis. }\end{array}$ & $\begin{array}{l}\text { Parent may be reluctant } \\
\text { to involve child in } \\
\text { consultation/wants to } \\
\text { tell the child/assumes it } \\
\text { is someone else's job to } \\
\text { tell child. }\end{array}$ & $\begin{array}{l}\text { "I wonder how much } \\
\text { you think insert child's } \\
\text { name knows about their } \\
\text { health at the moment?" } \\
\text { "Thinking about talking } \\
\text { to insert child's name } \\
\text { about this probably feels } \\
\text { the hardest thing in the } \\
\text { world. It's completely } \\
\text { understandable to want } \\
\text { to protect them from } \\
\text { this news. But we do } \\
\text { know that children are } \\
\text { very good at picking up }\end{array}$ \\
\hline
\end{tabular}




\begin{tabular}{|c|c|c|c|}
\hline & & & $\begin{array}{l}\text { on changes around } \\
\text { them, and helping } \\
\text { children understand } \\
\text { what is going on can } \\
\text { help them feel less } \\
\text { frightened and alone. It } \\
\text { will also enable you to } \\
\text { support them without } \\
\text { having to pretend." } \\
\text { "We are here to support } \\
\text { you with this." }\end{array}$ \\
\hline $\begin{array}{ll}\text { Build } & a \\
\text { relationship } & \end{array}$ & $\begin{array}{l}\text { Patients and parents value respect, trust and empathy. } \\
\text { Use the child's name when talking to the child and family } \\
\text { (ensures consultation feels personal despite being in a } \\
\text { large hospital or busy clinic). } \\
\text { Respect parents' and patients' existing knowledge around } \\
\text { the condition, care or situation and treat them as an equal, } \\
\text { respecting their own expertise in their personal lives and } \\
\text { experiences. }\end{array}$ & $\begin{array}{l}\text { Parents may share a } \\
\text { different understanding } \\
\text { of events or symptoms } \\
\text { leading up to the } \\
\text { consultation. }\end{array}$ & $\begin{array}{l}\text { "Are there any questions } \\
\text { that you feel are } \\
\text { important for us to try } \\
\text { and answer today?" }\end{array}$ \\
\hline Listen first & $\begin{array}{l}\text { Elicit the child and parents' story. } \\
\text { Determine what the child knows already. } \\
\text { Ask the child what they think is happening. } \\
\text { Use this information to evaluate the child's level of } \\
\text { autonomy and independence so that information can be } \\
\text { directed accordingly, e.g. adolescents may want to take } \\
\text { the lead in consultations. Children and adolescents should } \\
\text { be given the opportunity to talk to the health-care }\end{array}$ & $\begin{array}{l}\text { Acknowledge that child } \\
\text { may not want to speak } \\
\text { at that moment. } \\
\text { A challenge when time- } \\
\text { limited is to allow } \\
\text { sufficient time to listen. } \\
\text { Appreciate that some } \\
\text { older children/young } \\
\text { people talking on certain }\end{array}$ & $\begin{array}{l}\text { "Tell me a little bit about } \\
\text { what's been happening } \\
\text { recently, leading up to } \\
\text { being here today?" } \\
\text { "Tell me what Mum or } \\
\text { Dad told you about why } \\
\text { we're meeting today?" } \\
\text { "What do you know } \\
\text { about what's happening }\end{array}$ \\
\hline
\end{tabular}




\begin{tabular}{|c|c|c|c|}
\hline & $\begin{array}{l}\text { professional alone to allow them to raise subjects they do } \\
\text { not wish to share with their parents. } \\
\text { Note: even older adolescents and young adults may } \\
\text { appreciate the involvement of their parents in } \\
\text { consultations. }\end{array}$ & $\begin{array}{l}\text { topics may not want } \\
\text { their parent(s) present. } \\
\text { May need to use } \\
\text { different approaches to } \\
\text { conversations with } \\
\text { different children. } \\
\text { Children may lack } \\
\text { confidence and/or self- } \\
\text { advocacy skills. }\end{array}$ & $\begin{array}{l}\text { to you? How do you feel } \\
\text { about this?" }\end{array}$ \\
\hline Language & $\begin{array}{l}\text { Decide beforehand if you will name the life-threatening } \\
\text { condition and consider implications of decision (consider } \\
\text { age of child). } \\
\text { Be consistent. } \\
\text { Use clear language and avoid euphemisms or technical } \\
\text { jargon. This prevents children feeling excluded or } \\
\text { patronised by language they do not understand or feel is } \\
\text { not tailored to them. } \\
\text { Explain technical terms and jargon where necessary. } \\
\text { After you have named the condition, stop for a few } \\
\text { seconds to allow the family to take in what you have said. } \\
\text { Then, sensitively check family's knowledge and } \\
\text { understanding of the condition. }\end{array}$ & $\begin{array}{l}\begin{array}{l}\text { Parent or child may } \\
\text { google name of } \\
\text { diagnosis. }\end{array} \\
\text { Child may talk to peers } \\
\text { e.g. in a ward setting. }\end{array}$ & $\begin{array}{l}\text { "Have you heard of } \\
\text { insert name of } \\
\text { condition? What do you } \\
\text { understand or know } \\
\text { about insert name of } \\
\text { condition?" } \\
\text { "What name do you } \\
\text { usually use for your } \\
\text { condition?" } \\
\text { "What do you already } \\
\text { know about your } \\
\text { condition?" }\end{array}$ \\
\hline $\begin{array}{l}\text { Information } \\
\text { delivery in a } \\
\text { timely fashion }\end{array}$ & Be honest and realistic. & $\begin{array}{l}\text { Uncertainty may exist } \\
\text { about prognosis (if so, } \\
\text { acknowledge this). } \\
\text { Children and their } \\
\text { families vary in the }\end{array}$ & $\begin{array}{l}\text { "Is there anything you } \\
\text { would like me to expand } \\
\text { on right now?" } \\
\text { "Would you like to know } \\
\text { everything in detail }\end{array}$ \\
\hline
\end{tabular}




\begin{tabular}{|c|c|c|c|}
\hline & & $\begin{array}{l}\text { timescale over which } \\
\text { they wish to receive } \\
\text { information. } \\
\text { Parents and children } \\
\text { might want different } \\
\text { amounts of information. } \\
\text { Parents might feel very } \\
\text { anxious about talking } \\
\text { about prognosis in front } \\
\text { of their child. }\end{array}$ & $\begin{array}{l}\text { now? If not, how do you } \\
\text { prefer to find out about } \\
\text { things?" }\end{array}$ \\
\hline $\begin{array}{ll}\text { Pace } & \text { of } \\
\text { information } & \\
\text { delivery } & \end{array}$ & $\begin{array}{l}\text { Provide simple, measured pieces of information. } \\
\text { Pause to allow the family and child time to assimilate what } \\
\text { you have said. Especially important after you name the } \\
\text { diagnosis. } \\
\text { Look for child/parents' reactions to gauge when they are } \\
\text { ready for more information. } \\
\text { Communicate on child's terms and with support from } \\
\text { parents. } \\
\text { Identify child's priorities and tailor information } \\
\text { accordingly e.g. some young people's primary concern will } \\
\text { be hair loss or whether hospital admission will interfere } \\
\text { with a forthcoming social event, rather than treatment } \\
\text { options. }\end{array}$ & $\begin{array}{l}\text { Challenge is lack of cues } \\
\text { from child or parents. } \\
\text { Restrictions on time } \\
\text { available for discussion. } \\
\text { Be aware of emotional } \\
\text { distress, fatigue or pain } \\
\text { that may limit capacity } \\
\text { to absorb information. }\end{array}$ & $\begin{array}{l}\text { "Have you heard of } \\
\text { insert } \\
\text { before?" } \\
\text { If so, "What do you } \\
\text { understand about insert } \\
\text { diagnosis?" } \\
\text { "Do I need to slow } \\
\text { down? Would you like } \\
\text { me to go over anything } \\
\text { again?" }\end{array}$ \\
\hline $\begin{array}{l}\text { Sources of } \\
\text { information }\end{array}$ & $\begin{array}{l}\text { Provide visual as well as verbal information. } \\
\text { Provide details of other sources of information (e.g. } \\
\text { support group, useful websites or resources e.g. }\end{array}$ & $\begin{array}{l}\text { Avoids information from } \\
\text { unreliable websites or } \\
\text { unhelpful social media. }\end{array}$ & $\begin{array}{l}\text { "Would it help if I wrote } \\
\text { down some of the things } \\
\text { that we talked about } \\
\text { today?" }\end{array}$ \\
\hline
\end{tabular}




\begin{tabular}{|c|c|c|c|}
\hline & $\begin{array}{l}\text { http://www.clicsargent.org.uk/content/storybooks- } \\
\text { children } \\
\text { http://healthtalk.org/content/talking-children-about- } \\
\text { their-life-threatening-illness } \\
\text { Honest answers Sound Advice: A Young person's Guide to } \\
\text { Cancer www.teenagecancertrust.org). } \\
\text { Give child information to take away. } \\
\text { Consider options to connect with another family with } \\
\text { similar experiences to help guide them through (based on } \\
\text { family preference). }\end{array}$ & & $\begin{array}{l}\text { "Would a picture be } \\
\text { helpful to understand } \\
\text { what we talked about?" } \\
\text { "Shall I show you some } \\
\text { photographs to explain } \\
\text { what I mean?" } \\
\text { "Would it help to talk to } \\
\text { someone else with a } \\
\text { similar illness?" }\end{array}$ \\
\hline $\begin{array}{l}\text { Pay attention to } \\
\text { emotional } \\
\text { understanding }\end{array}$ & $\begin{array}{l}\text { Follow the child's cues about their emotional } \\
\text { understanding of the information. } \\
\text { Allow child to express their feelings and explain these are } \\
\text { normal in this situation. }\end{array}$ & $\begin{array}{l}\text { Child's silence may } \\
\text { indicate they have } \\
\text { understood all or very } \\
\text { little of the information. } \\
\text { It is important to check } \\
\text { with the child what they } \\
\text { have understood. } \\
\text { Possibility of } \\
\text { misinterpretation of } \\
\text { behaviour. }\end{array}$ & $\begin{array}{l}\text { "Did you know many } \\
\text { other children often feel } \\
\text { very sad, confused or } \\
\text { frightened; how do you } \\
\text { feel about this? Is there } \\
\text { anything you want to } \\
\text { say?" }\end{array}$ \\
\hline $\begin{array}{l}\text { Acknowledge } \\
\text { quantity of } \\
\text { information } \\
\text { given }\end{array}$ & $\begin{array}{l}\text { Reassure the family that feelings of shock and distress are } \\
\text { normal and make it very difficult to process information. }\end{array}$ & $\begin{array}{l}\text { Religious, spiritual and } \\
\text { cultural beliefs might } \\
\text { need to be taken into } \\
\text { consideration. } \\
\text { Limited opportunities to } \\
\text { talk to family again. }\end{array}$ & $\begin{array}{l}\text { "Do you feel ready to } \\
\text { hear some more about } \\
\text { this now?" } \\
\text { "Would you like me to } \\
\text { write anything down for } \\
\text { you?" }\end{array}$ \\
\hline
\end{tabular}




\begin{tabular}{|c|c|c|c|}
\hline $\begin{array}{l}\text { Ask child and } \\
\text { parents what } \\
\text { they have } \\
\text { understood } \\
\text { about what has } \\
\text { been said }\end{array}$ & $\begin{array}{l}\text { Check family are familiar with any medical terms used and } \\
\text { whether there are local cultural meanings that need to be } \\
\text { recognised. } \\
\text { Try and gauge understanding of all involved to ensure no } \\
\text { one is getting lost in the conversation. } \\
\text { Check understanding throughout the conversation. } \\
\text { If possible, ask the child what they understood. } \\
\text { Provide parent and child with opportunity to ask } \\
\text { questions. } \\
\text { Reassure child and family there will be further } \\
\text { opportunities to ask questions. }\end{array}$ & $\begin{array}{l}\text { Important to ensure } \\
\text { communication at } \\
\text { correct developmental } \\
\text { level. Some parents and } \\
\text { young people are very } \\
\text { familiar with medical } \\
\text { language and } \\
\text { procedures, whereas } \\
\text { others are not. }\end{array}$ & $\begin{array}{l}\text { "I know that it can be } \\
\text { difficult to take this all } \\
\text { in." } \\
\text { "Is there anything you } \\
\text { do not understand or } \\
\text { would like me to explain } \\
\text { further?" } \\
\text { "Can I check how well } \\
\text { I've explained things } \\
\text { today? Would you like to } \\
\text { tell me what you've } \\
\text { understood so far?" } \\
\text { "Some families find it } \\
\text { helpful to write all their } \\
\text { questions down and } \\
\text { bring them to their next } \\
\text { appointment." }\end{array}$ \\
\hline Make a Plan & $\begin{array}{l}\text { Explain to family what will happen next. } \\
\text { Give family an idea of timescale for next steps, or, if } \\
\text { unclear, when timescale will be clarified, including when } \\
\text { their next appointment will be. } \\
\text { Reassure families they will not have to manage this alone } \\
\text { - if possible provide telephone/email contact details. } \\
\text { If appropriate and/or available explain that symptoms can } \\
\text { be controlled by medication, especially pain. }\end{array}$ & $\begin{array}{l}\text { Challenges in resource- } \\
\text { limited settings } \\
\text { including lack of phones, } \\
\text { difficulties attending } \\
\text { health clinic } \\
\text { appointments. }\end{array}$ & $\begin{array}{l}\text { To the child: } \\
\text { "You must let us know if } \\
\text { anything hurts or feels } \\
\text { funny." } \\
\text { To the parent(s): } \\
\text { "We know that you } \\
\text { know your child inside } \\
\text { and out. If you have any } \\
\text { concerns, feel they are } \\
\text { in pain or something is }\end{array}$ \\
\hline
\end{tabular}




\begin{tabular}{|l|l|l|l|}
\hline & $\begin{array}{l}\text { Consider other sources of support for family e.g. } \\
\text { community health-care professionals. } \\
\begin{array}{l}\text { Communicate with other health-care professionals } \\
\text { involved e.g. General Practitioner. }\end{array}\end{array}$ & $\begin{array}{l}\text { wrong, then don't } \\
\text { hesitate to contact the } \\
\text { team. We appreciate } \\
\text { you are the expert in } \\
\text { your child and we will } \\
\text { always work with you." }\end{array}$ \\
\hline
\end{tabular}




\section{Acknowledgements:}

The study was funded by The John Fell Fund, University of Oxford and The Sheila Kitzinger Programme, Green Templeton College, Oxford supported the workshop.

We are grateful to Duncan West and Melissa de Lusignan for facilitating the expert workshop. We are also grateful to Valerie West, Mike Beckles, Nia Roberts, Hannah DeJong, Elise Sellars and patient and public involvement from from Meriel Flint an adult who had cancer as an adolescent, and a young adult with a LTC (written permission obtained).

\section{Authors' contributions}

Alan Stein (AS) conceptualized and the designed the review. Louise Dalton (LD), Lucy Hanington (LH), Kim Fredman Stein (KFS) and AS undertook the literature searches and selected the studies. AS, LD and Elizabeth Rapa (ER) gathered the information from the studies and drafted the manuscript. Myra Bluebond-Langner (MBL), Sue Ziebland (SZ), Emily Harrop (EH), Ruth Bland (RB), Brenda Kelly (BK), Tamsen Rochat (TR) and KFS provided specific input to different sections of the manuscript; Communication Expert Group commented on drafts of the manuscript and contributed to the development of the guidelines. LD and ER compiled the tables. All authors have read and approved the final version of the Review.

\section{Conflict of Interest statements}

EH declares she is deputy chair of the NICE clinical guideline development committee for NG61 (End of Life Care in Infants, Children and Young People).

All of the other authors declare no Conflicts of Interest

\section{Role of funding source}

The funder of the study had no role in any aspect of the review.

\section{Communication Expert Group:}

Professor Theresa Betancourt SC.D., Boston College, Massachusetts, USA

Catherine D'Souza MRCP. South Canterbury District Health Board, New Zealand

Mina Fazel MRCPsych. University of Oxford, Oxford, UK

Professor Daniel Hochhauser DPhil. UCL Cancer Institute, London, UK

Barbara Kolucki MA. Communication and Children in Difficult Circumstances UNICEF Consultant, New York, USA

Aoife C Lowney MRCP. Oxford University Hospitals NHS Foundation Trust and Sir Michael Sobell

House, Oxford, UK

Elena Netsi D.Phil. University of Oxford, Oxford, UK

Professor Linda Richter PhD. University of the Witwatersrand, Johannesburg, South Africa

Aisha Yousafzai PhD. Harvard T.H.Chan School of Public Health, Massachusetts, USA 


\section{Appendix}

\section{Methods}

1. Literature Review

A narrative approach was used to undertake a comprehensive overview of the available literature and address the wide-ranging research questions outlined above. This inclusive methodology was particularly important given the breadth of available literature, ranging from large-scale randomised controlled trials (RCTs) to qualitative studies exploring the detail of patient experiences. The search strategy focused on publications since 2000, but in the context of evolutionary changes in healthcare philosophy around communication, different rates of change across HICs and LMICs, and gaps in the recent literature, we also included earlier studies and hand searched reference lists of papers selected (see Box 1 and 2 for search strategy and selection criteria). We focused on children and adolescents up to and including the age of 18 years, although a minority of studies in this review also include young adults. We have used the term children to refer to both children and adolescents and have specified the age range of participants within each study.

\section{Expert Group Workshop and Development of Framework}

In the context of the available research evidence and limited child-focused evidence-based guidelines, an interdisciplinary expert group was convened to integrate the research literature and the theoretical and clinical experience of the members to develop a framework for communication. The workshop was attended by 16 professionals and an additional 4 members contributed to subsequent discussions, review and framework development to create an expert group $(n=20)$. The group members had experience of working in HICs (Denmark, Sweden, UK, USA) and LMICs (Cameroon, Laos, Mozambique, Myanmar, Pacific Countries of Vanuatu and Fiji, Pakistan, Rwanda, Sierra Leone, South Africa, Tajikistan, Tanzania, Timor-Leste, Uganda) with backgrounds in psychology, psychiatry, paediatrics, oncology, palliative care, global health, child development, child protection, health and human rights, education, anthropology and sociology.

The workshop included presentations on the literature review in HICs and LMICs and the academic and clinical work of the assembled group. Although caregivers and children were not direct participants of this workshop, a series of videos presenting parents' perspectives about talking to children about LTCs were reviewed (http://healthtalk.org/content/talking-children-about-their-lifethreatening-illness) along with focus group data from adolescents (12-18yrs) in the Together For Short Lives consultation commissioned by NICE. Following extensive discussion, core principles were derived to develop a framework. This was then further refined through consensus to create a series of guidelines. In this iterative process, information gaps were identified and future research direction discussed. The framework was also reviewed by a young adult who had cancer during their adolescence, and a young adult who has had an LTC since childhood.

BOX 1 - Search strategy and selection criteria

Data for this Review were identified using CINHAL (EBSCOHOst)[from 1982], Embase (OvidSP)[19742016 May 11], Medline(OvidSP)[from 1946], PsycINFO(OvidSP)[1967-April Week 1 2016], Science Citation Index \& Social Science Citation Index(Web of Science Core Collection)[1945-2018]. We used a combination of keywords in title/abstract and subject headings for the following key concepts: 
children, communication and life-threatening illness and we applied a search filter to identify systematic reviews of qualitative studies. Commentary, letters, conference abstracts, dissertations and case reports were excluded. See appendix for search strategy. 5427 records were identified of which 2132 were duplicates. 2281 potentially relevant articles and reviews were reviewed by LH, KFS and LD. Our final sample consisted of 57 articles from the search and 44 articles identified from references of relevant articles.

BOX 2 - Search strategy used in Medline (OvidSP)[from 1946]. Other strategies are available on request.

\begin{tabular}{|c|c|c|}
\hline $\begin{array}{l}\# \\
\Delta\end{array}$ & Searches & Results \\
\hline 1 & $\begin{array}{l}\text { (child* or schoolchild* or pediatric* or paediatric* or boys or girls or adolescen* } \\
\text { or teen* or youth? or young people or young person?).ti. }\end{array}$ & 882902 \\
\hline 2 & communication/ or information seeking behavior/ & 69970 \\
\hline 3 & $\begin{array}{l}\text { (nurse-patient relations/ or physician-patient relations/) and (communicat* or } \\
\text { talk* or discuss* or disclose? or disclosure).mp. }\end{array}$ & 29711 \\
\hline 4 & $\begin{array}{l}\text { (parent-child relations/ or father-child relations/ or mother-child relations/) and } \\
\text { (communicat* or talk* or discuss* or disclose? or disclosure).mp. }\end{array}$ & 9697 \\
\hline 5 & Truth Disclosure/ & 12260 \\
\hline 6 & (communicat* or talk* or discuss* or disclose? or disclosure).ti. & 97059 \\
\hline 7 & $\begin{array}{l}\text { ((communicat* or talk* or tell* or told or discuss* or disclose? or disclosure) adj3 } \\
\text { (truth or diagnos* or prognos* or death or dying or terminal*)).ti,ab. }\end{array}$ & 20672 \\
\hline 8 & 2 or 3 or 4 or 5 or 6 or 7 & 191951 \\
\hline 9 & 1 and 8 & 14897 \\
\hline 10 & $\begin{array}{l}\text { ((communicat* or talk* or discuss* or disclose? or disclosure) adj3 (child* or } \\
\text { schoolchild* or pediatric* or paediatric* or boys or girls or adolescen* or teen* or } \\
\text { youth? or young people or young person?)).ti,ab. }\end{array}$ & 12176 \\
\hline 11 & 9 or 10 & 23230 \\
\hline 12 & Attitude to Death/ & 14364 \\
\hline 13 & exp Terminal Care/ or Terminally III/ & 46221 \\
\hline 14 & Palliative Care/ & 44439 \\
\hline 15 & exp Advance Directives/ & 6332 \\
\hline 16 & ((lifethreaten* or life threaten* or terminal*) adj2 (ill* or condition?)).ti,ab. & 13522 \\
\hline 17 & $\begin{array}{l}\text { (advanced directive? or living will? or "do not resuscitate" or resuscitation order? } \\
\text { or assisted suicide?).ti,ab. }\end{array}$ & 5701 \\
\hline 18 & ((place or home or hospice) adj2 (die or dying or death)).ti,ab. & 2190 \\
\hline 19 & $\begin{array}{l}\text { ((palliative or hospice? or "end of life" or terminal) adj2 (care or therap* or } \\
\text { treat*)).ti,ab. }\end{array}$ & 36763 \\
\hline 20 & $\begin{array}{l}\text { *neoplasms/ or exp *breast neoplasms/ or exp *colorectal neoplasms/ or exp } \\
\text { *testicular neoplasms/ }\end{array}$ & 647765 \\
\hline 21 & exp *leukemia/ or exp *lymphoma/ & 275110 \\
\hline 22 & *Brain Neoplasms/ & 76640 \\
\hline 23 & (cancer* or carcinoma? or tumour? or tumor? or malignan* or metasta*).ti. & 1562751 \\
\hline 24 & $\begin{array}{l}\text { ((breast or testic* or colon* or bowel or colorect* or colo-rect* or brain) adj3 } \\
\text { (cancer* or carcinoma? or tumour? or tumor? or malignan* or metasta*)).ti,ab. }\end{array}$ & 445150 \\
\hline 25 & (leukaemia or leukemia or lymphoma?).ti,ab. & 330877 \\
\hline 26 & *hiv infections/di & 7520 \\
\hline
\end{tabular}




\begin{tabular}{|l|l|l|}
\hline 27 & $\begin{array}{l}\text { ((hiv or human immunodeficiency virus?) adj3 (disclose? or disclosure or diagnos* } \\
\text { or prognos*)).ti,ab. }\end{array}$ & 11046 \\
\hline 28 & Hemorrhagic Fever, Ebola/ & 2784 \\
\hline 29 & ebola.ti,ab. & 4794 \\
\hline 30 & $\begin{array}{l}\text { 12 or } 13 \text { or } 14 \text { or } 15 \text { or } 16 \text { or } 17 \text { or } 18 \text { or } 19 \text { or } 20 \text { or } 21 \text { or } 22 \text { or } 23 \text { or } 24 \text { or } 25 \text { or } \\
26 \text { or } 27 \text { or } 28 \text { or } 29\end{array}$ & 2278846 \\
\hline 31 & 11 and 30 & 1744 \\
\hline 32 & limit 31 to "reviews (maximizes specificity)" & 23 \\
\hline 33 & (Qualitative systematic review* or (systematic review and qualitative)).ti,ab. & 3131 \\
\hline 34 & (evidence synthesis or realist synthesis).ti,ab. & 2023 \\
\hline 35 & (Qualitative and synthesis).ti,ab. & 4232 \\
\hline 36 & (meta-synthesis* or meta synthesis* or metasynthesis).ti,ab. & 559 \\
\hline 37 & (meta-ethnograph* or metaethnograph* or meta ethnograph*).ti,ab. & 269 \\
\hline 38 & (meta-study or metastudy or meta study).ti,ab. & 65 \\
\hline 39 & (realist review? or realist synthesis).ti,ab. & 199 \\
\hline 40 & systematic review*.ti,ab. and qualitative research/ & 416 \\
\hline 41 & 33 or 34 or 35 or 36 or 37 or 38 or 39 or 40 & 8731 \\
\hline 42 & 31 and 41 & 4 \\
\hline 43 & 32 or 42 & 24 \\
\hline
\end{tabular}


Table 1: Studies concerning communication with children and adolescents about the diagnosis of their own Life Threatening Condition

\begin{tabular}{|c|c|c|c|c|c|c|c|c|c|c|}
\hline Author & $\begin{array}{l}\text { Qualitative or } \\
\text { Quantitative }\end{array}$ & $\begin{array}{l}\text { Size of } \\
\text { study } \\
\text { (n) }\end{array}$ & $\begin{array}{l}\text { Type of } \\
\text { participant }\end{array}$ & $\begin{array}{l}\text { Child } \\
\text { Age } \\
\text { range in } \\
\text { years } \\
\text { (mean) }\end{array}$ & $\begin{array}{l}\text { Child } \\
\text { diagnosis }\end{array}$ & $\begin{array}{l}\text { Method of } \\
\text { recruitment }\end{array}$ & $\begin{array}{l}\text { Method \& } \\
\text { measures }\end{array}$ & $\begin{array}{l}\text { How was } \\
\text { communication } \\
\text { assessed? }\end{array}$ & Results & Location \\
\hline $\begin{array}{l}\text { Abadia- } \\
\text { Barrero and } \\
\text { Larusso } \\
2006^{57}\end{array}$ & Qualitative & 36 & $\begin{array}{l}\text { Children \& } \\
\text { adolescent } \\
\text { s; } 18 \text { HIV } \\
\text { positive, } 18 \\
\text { HIV } \\
\text { negative, } \\
\text { all of } \\
\text { whom had } \\
\text { lost one or } \\
\text { more } \\
\text { caregivers } \\
\text { to } \\
\text { HIV/AIDS }\end{array}$ & $1-15$ & $\begin{array}{l}\text { HIV positive } \\
\text { \& HIV } \\
\text { negative }\end{array}$ & $\begin{array}{l}\text { Support house } \\
\text { that shelters } \\
\text { children } \\
\text { orphaned by } \\
\text { HIV/AIDS }\end{array}$ & $\begin{array}{l}\text { Open } \\
\text { communication if } \\
\text { words HIV/AIDS } \\
\text { used. Participant } \\
\text { observation \& semi } \\
\text { structured } \\
\text { interviews }\end{array}$ & $\begin{array}{l}\text { Qualitative analysis of } \\
\text { interviews \& } \\
\text { observations }\end{array}$ & $\begin{array}{l}\text { Children curious about their } \\
\text { HIV/AIDS related } \\
\text { experiences but most adults } \\
\text { did not give direct } \\
\text { explanations, or gave } \\
\text { confusing or contradictory } \\
\text { answers which inhibited } \\
\text { children asking. Children's } \\
\text { understanding of their } \\
\text { difference based on } \\
\text { taking/not taking } \\
\text { medication. } 7-9 \text { year olds } \\
\text { understand being sick \& } \\
\text { AIDS as negative, but are } \\
\text { confused as to the relevance } \\
\text { to their life. Preadolescents } \\
\text { start to acquire knowledge } \\
\text { about the disease but have } \\
\text { many misunderstandings. } \\
\text { Adolescents' growing } \\
\text { awareness of the } \\
\text { relationship between their } \\
\text { lives \& negative social } \\
\text { values associated with HIV } \\
\text { creates shame \& anger. } \\
\text { Adolescents with HIV have } \\
\text { poor understanding of the } \\
\text { implications of HIV for their } \\
\text { lives \& future risks to their } \\
\text { health. Absence of support } \\
\text { can result in inadvertent risk } \\
\text { taking behaviour }\end{array}$ & Brazil \\
\hline $\begin{array}{l}\text { Adduci, } \\
\text { Jankovic et } \\
\text { al. } 2012^{33}\end{array}$ & $\begin{array}{l}\text { Mixed } \\
\text { methods }\end{array}$ & 128 & $\begin{array}{l}64 \\
\text { children; } \\
64 \text { parents }\end{array}$ & $4-18$ & Brain tumour & $\begin{array}{l}\text { Neuro rehab unit } \\
\text { (received } \\
\text { treatment at least } \\
1 \text { year before). } \\
\text { Children with } \\
\text { psychological \& }\end{array}$ & $\begin{array}{l}\text { CBCL; VABS. } \\
\text { Semi structured } \\
\text { interviews with } \\
\text { parents \& children } \\
\text { (separately) }\end{array}$ & $\begin{array}{l}\text { Communication } \\
\text { classified as: Avoidance } \\
\text { (child did not receive } \\
\text { any information or } \\
\text { explanation about } \\
\text { disease, or denial of }\end{array}$ & $\begin{array}{l}\text { Significant relationship } \\
\text { between the onset of } \\
\text { internalising problems, } \\
\text { withdrawal, anxiety- } \\
\text { depression \& social } \\
\text { problems with the presence }\end{array}$ & Italy \\
\hline
\end{tabular}




\begin{tabular}{|c|c|c|c|c|c|c|c|c|c|c|}
\hline & & & & & & $\begin{array}{l}\text { behavioural } \\
\text { problems prior to } \\
\text { onset of disease, } \\
\& \text { those who } \\
\text { received } \\
\text { psychological } \\
\text { support at, or } \\
\text { after diagnosis } \\
\text { were excluded }\end{array}$ & & $\begin{array}{l}\text { disease \& relevant } \\
\text { treatment course); } \\
\text { Ineffective (if only one } \\
\text { of characteristics } \\
\text { present - } \\
\text { incomplete/untruthful/i } \\
\text { nconsistent/incomprehe } \\
\text { nsible/discontinuous/im } \\
\text { personal); Effective } \\
\text { (possess all } 6 \text { of } \\
\text { complete/truthful/consi } \\
\text { stent/comprehensibe/c } \\
\text { ontinuous/personalised } \\
\text { information }\end{array}$ & $\begin{array}{l}\text { of avoidance of ineffective } \\
\text { communication about the } \\
\text { disease }\end{array}$ & \\
\hline $\begin{array}{l}\text { Arun, Singh } \\
\text { et al. } 2009^{100}\end{array}$ & Quantitative & 50 & Caregivers & $\begin{array}{l}\text { Mean } \\
8.98\end{array}$ & HIV & HIV clinics & $\begin{array}{l}\text { Structured } \\
\text { interviews including } \\
\text { questions about } \\
\text { child's disclosure } \\
\text { status, information } \\
\text { given to child about } \\
\text { disease \& caregiver } \\
\text { perceptions about } \\
\text { disclosure. Care } \\
\text { giver report } \\
\text { children either } \\
\text { aware, or unaware } \\
\text { of HIV status }\end{array}$ & $\begin{array}{l}\text { Caregiver report of } \\
\text { child's awareness of HIV } \\
\text { status }\end{array}$ & $\begin{array}{l}14 \% \text { of children aware of } \\
\text { their HIV status (according } \\
\text { to caregiver report). } 68 \% \text { of } \\
\text { children had been given no } \\
\text { information, } 26 \% \text { told } \\
\text { another diagnosis \& } 6 \% \\
\text { given factual information. Of } \\
\text { the children on ART, } 10 \% \\
\text { were told for HIV infection; } \\
\text { majority of children told } \\
\text { nothing or told for } \\
\text { improving general health or } \\
\text { other physical ailments. } 44 \% \\
\text { of caregivers favoured HIV } \\
\text { disclosure, with mid teenage } \\
\text { as the appropriate age for } \\
\text { disclosure }\end{array}$ & India \\
\hline $\begin{array}{l}\text { Badarau, } \\
\text { Wangmo et } \\
\text { al. } 2015^{71}\end{array}$ & Qualitative & 28 & $\begin{array}{l}18 \text { parents; } \\
10 \\
\text { oncologists }\end{array}$ & $8-18$ & $\begin{array}{l}\text { Cancer } \\
\text { (leukemia, } \\
\text { lymphoma, } \\
\text { CNS, } \\
\text { sarcoma, } \\
\text { other) }\end{array}$ & $\begin{array}{l}3 \text { hospital cancer } \\
\text { centres }\end{array}$ & $\begin{array}{l}\text { Semi structured } \\
\text { interviews including } \\
\text { experiences of } \\
\text { diagnosis \& } \\
\text { treatment, } \\
\text { communication \& } \\
\text { decision making, } \\
\text { attitudes to child } \\
\text { involvement in } \\
\text { healthcare }\end{array}$ & Thematic analysis & $\begin{array}{l}\text { Parents reported too much } \\
\text { information or high levels of } \\
\text { emotional distress inhibited } \\
\text { communication with child. } \\
\text { Parents reported feeling } \\
\text { unsure \& unprepared about } \\
\text { talking to child re diagnosis. } \\
\text { Parents fearful information } \\
\text { would cause child distress. } \\
\text { Physicians highlighted } \\
\text { tension between wanting to } \\
\text { inform patient of diagnosis } \\
\text { \& implications, \& desire of } \\
\text { parents to withhold } \\
\text { information }\end{array}$ & Romania \\
\hline
\end{tabular}




\begin{tabular}{|c|c|c|c|c|c|c|c|c|c|c|}
\hline $\begin{array}{l}\text { Bikaako- } \\
\text { Kajura, } \\
\text { Luyirika et al. } \\
2006^{55}\end{array}$ & Qualitative & 84 & $\begin{array}{l}42 \text { children } \\
\text { taking ART; } \\
42 \text { primary } \\
\text { caregivers }\end{array}$ & $\begin{array}{l}5-17( \\
\text { median } \\
12)\end{array}$ & HIV & $\begin{array}{l}\text { HIV clinics using } \\
\text { selection matrix } \\
\text { to include } \\
\text { younger \& older } \\
\text { children who had } \\
\& \text { had not been } \\
\text { disclosed to }\end{array}$ & $\begin{array}{l}\text { Semi structured } \\
\text { interviews including } \\
\text { disclosure, } \\
\text { adherence \& } \\
\text { associated } \\
\text { challenges. } \\
\text { Disclosure } \\
\text { categorised as: } \\
\text { Complete parental } \\
\text { disclosure (both } \\
\text { caregiver \& child } \\
\text { concur caregiver } \\
\text { told child their HIV } \\
\text { disease \& } \\
\text { medication); Non- } \\
\text { disclosure ( } \\
\text { caregivers had not } \\
\text { disclosed child's HIV } \\
\text { status \& report } \\
\text { child does not } \\
\text { suspect they are } \\
\text { HIV positive); } \\
\text { Partial disclosure } \\
\text { (child not fully } \\
\text { aware of HIV, but } \\
\text { suspicious, asks Q } \\
\text { of caregiver about } \\
\text { disease \& drug \& in } \\
\text { many cases } \\
\text { assumes the drug is } \\
\text { a cure, caregiver } \\
\text { has postponed } \\
\text { disclosure, lied } \\
\text { during disclosure } \\
\text { process or child } \\
\text { learned of status } \\
\text { from an external } \\
\text { person or through } \\
\text { overhearing } \\
\text { conversations) }\end{array}$ & $\begin{array}{l}\text { Disclosure status \& } \\
\text { coding of interviews }\end{array}$ & $\begin{array}{l}\text { Complete disclosure \& } \\
\text { strong parental relationships } \\
\text { related to good adherence. } \\
\text { Children who had had full } \\
\text { disclosure became self- } \\
\text { motivated to adhere \& were } \\
\text { able to overcome external } \\
\text { adherence challenges. As } \\
\text { children became suspicious } \\
\text { about their HIV status, } \\
\text { ongoing lack of disclosure } \\
\text { resulted in intentional non } \\
\text { adherence by some children }\end{array}$ & Uganda \\
\hline $\begin{array}{l}\text { Binger, Ablin } \\
\text { et al. } 1969^{87}\end{array}$ & Qualitative & $\begin{array}{l}20 \\
\text { familie } \\
\mathrm{s}\end{array}$ & $\begin{array}{l}\text { Bereaved } \\
\text { parents }\end{array}$ & $\mathrm{N} / \mathrm{A}$ & Leukaemia & $\begin{array}{l}\text { Child's medical } \\
\text { team }\end{array}$ & $\begin{array}{l}\text { Semi structured } \\
\text { interviews including } \\
\text { details around } \\
\text { diagnosis, } \\
\text { relationships with }\end{array}$ & Content analysis & $\begin{array}{l}\text { Parents appreciated HCPs' } \\
\text { frankness \& honesty about } \\
\text { child's diagnosis \& } \\
\text { implications. Some families } \\
\text { reported HCP became more }\end{array}$ & USA \\
\hline
\end{tabular}




\begin{tabular}{|c|c|c|c|c|c|c|c|c|c|c|}
\hline & & & & & & & $\begin{array}{l}\text { HCPs \& short/long } \\
\text { term impact on } \\
\text { family }\end{array}$ & & $\begin{array}{l}\text { remote \& avoided their child } \\
\text { as death approached. } \\
\text { Parents reported children } \\
\text { aware of seriousness of } \\
\text { their illness \& anticipated } \\
\text { death, even when not told. } \\
\text { Adolescents who were } \\
\text { aware did not experience } \\
\text { greater difficulty than those } \\
\text { who were naïve to their } \\
\text { situation \& parents reported } \\
\text { more meaningful } \\
\text { relationship as a result of } \\
\text { honesty about the diagnosis. } \\
\text { Patients tried to protect } \\
\text { their parents from knowing } \\
\text { they knew diagnosis. } \\
\text { Authors suggest HCPs } \\
\text { struggle with imminent } \\
\text { death of patients \& may } \\
\text { avoid families actively or } \\
\text { through "façade of } \\
\text { busyness" }\end{array}$ & \\
\hline $\begin{array}{l}\text { Beima-Sofie, } \\
\text { John-Stewart } \\
\text { et al. 2014 }\end{array}$ & Qualitative & 21 & $\begin{array}{l}\text { HCPs } \\
\text { involved in } \\
\text { care of HIV } \\
\text { positive } \\
\text { children }\end{array}$ & $0-17$ & HIV & $\begin{array}{l}\text { HCPs; selected to } \\
\text { represent diverse } \\
\text { array of settings. }\end{array}$ & $\begin{array}{l}\text { Individual semi } \\
\text { structured } \\
\text { interviews including } \\
\text { open ended } \\
\text { questions about } \\
\text { factors considered } \\
\text { in decisions about } \\
\text { whether to disclose } \\
\text { diagnosis, barriers } \\
\text { \& strategies used }\end{array}$ & $\begin{array}{l}\text { Thematic analysis \& } \\
\text { modified grounded } \\
\text { theory }\end{array}$ & $\begin{array}{l}\text { HCP experiences used to } \\
\text { develop an experience- } \\
\text { based framework to } \\
\text { describe current disclosure } \\
\text { practice. Providers had } \\
\text { limited training but } \\
\text { extensive experience in } \\
\text { disclosure. Providers } \\
\text { recognised importance of } \\
\text { relationship between child } \\
\& \text { caregivers, considering } \\
\text { caregiver concerns about } \\
\text { disclosure, its timing \& } \\
\text { implications. Cited benefits } \\
\text { of disclosure included } \\
\text { importance for } \\
\text { independence \& autonomy, } \\
\text { trust, preventing spread of } \\
\text { infection, medical } \\
\text { adherence \& psychological } \\
\text { health. Providers believe } \\
\text { planed disclosure mitigated } \\
\text { harm to the child from }\end{array}$ & Kenya \\
\hline
\end{tabular}




\begin{tabular}{|c|c|c|c|c|c|c|c|c|c|c|}
\hline & & & & & & & & & $\begin{array}{l}\text { overhearing their diagnosis } \\
\& \text { cited examples of } \\
\text { negative impact on } \\
\text { psychological wellbeing of } \\
\text { children who discovered } \\
\text { their diagnosis before } \\
\text { deliberate disclosure. HCPs } \\
\text { identified a number of } \\
\text { factors that should be } \\
\text { considered in terms of } \\
\text { timing of a disclosure, } \\
\text { including child's age, } \\
\text { understanding, adherence \& } \\
\text { social situation }\end{array}$ & \\
\hline $\begin{array}{l}\text { Biadgilign, } \\
\text { Deribew et } \\
\text { al. } 2011^{78}\end{array}$ & Quantitative & 390 & $\begin{array}{l}\text { Caregivers } \\
\text { of children } \\
\text { with HIV } \\
\text { receiving } \\
\text { HAART }\end{array}$ & $\begin{array}{l}1-14( \\
\text { median } \\
8.5)\end{array}$ & HIV & $\begin{array}{l}\text { Child's medical } \\
\text { team }\end{array}$ & $\begin{array}{l}\text { Individual semi } \\
\text { structured } \\
\text { interviews including } \\
\text { quality of } \\
\text { healthcare services } \\
\text { and diagnosis. } \\
\text { Disclosure classified } \\
\text { as 'disclosed' or } \\
\text { 'not aware' of HIV } \\
\text { status }\end{array}$ & Disclosure status & $\begin{array}{l}\text { HIV status known by } 17.4 \% \\
\text { of children in the study. } 46 \% \\
\text { of respondents reported } \\
\text { child should be told of their } \\
\text { HIV status when older than } \\
14 \text { years old. Children aged } \\
\text { under } 9 \text { \& those living with } \\
\text { educated caregivers less } \\
\text { likely to know their HIV } \\
\text { status. Children referred } \\
\text { from the inpatient wards of } \\
\text { the hospital before } \\
\text { attending clinic \& private } \\
\text { clinic were more likely to } \\
\text { know their status than those } \\
\text { from community clinic. } \\
60 \% \text { of caregivers believed } \\
\text { the doctor should be } \\
\text { responsible for giving the } \\
\text { child their diagnosis }\end{array}$ & Ethiopia \\
\hline $\begin{array}{l}\text { Blasini, } \\
\text { Chantry et al. } \\
2004^{48}\end{array}$ & $\begin{array}{l}\text { Mixed } \\
\text { methods }\end{array}$ & 95 & $\begin{array}{l}16 \text { HCPs; } \\
39 \\
\text { caregivers; } \\
40 \text { children }\end{array}$ & $\begin{array}{l}9- \\
>15(13.8 \\
)\end{array}$ & HIV & $\begin{array}{l}\text { Hospital HIV clinic } \\
\& \text { clinical trials } \\
\text { unit }\end{array}$ & $\begin{array}{l}\text { Quasi experimental } \\
\text { study using specific } \\
\text { model of disclosure } \\
\text { for patient, family \& } \\
\text { staff members. } \\
\text { Semi structured } \\
\text { interviews \& } \\
\text { questionnaires } \\
\text { (administered } \\
\text { before \& after } \\
\text { disclosure). } \\
\text { Educational cartoon }\end{array}$ & Disclosure status & $\begin{array}{l}\text { Most patients had feelings } \\
\text { of "normalcy" } 6 \text { months } \\
\text { post disclosure \& over half } \\
\text { had improved their } \\
\text { adherence to therapy after } \\
\text { disclosure, as reported by } \\
\text { patients \& caregivers. } 85 \% \\
\text { of patients \& } 97 \% \text { of } \\
\text { caregivers considered } \\
\text { disclosure a positive event } \\
\text { for themselves \& their } \\
\text { families. Fewer HCPs }\end{array}$ & Puerto Rico \\
\hline
\end{tabular}




\begin{tabular}{|c|c|c|c|c|c|c|c|c|c|c|}
\hline & & & & & & & $\begin{array}{l}\text { book about HIV } \\
\text { given to child }\end{array}$ & & $\begin{array}{l}\text { reported feelings of fear, } \\
\text { discomfort \& insecurity after } \\
\text { implementation of a } \\
\text { disclosure model }\end{array}$ & \\
\hline $\begin{array}{l}\text { Bluebond- } \\
\text { Langner } \\
1989^{21}\end{array}$ & Qualitative & 32 & $\begin{array}{l}\text { Parents; } \\
\text { HCPs; } \\
\text { children }\end{array}$ & $3-9$ & $\begin{array}{l}\text { Leukaemia, \& } \\
\text { other forms } \\
\text { of cancer }\end{array}$ & $\begin{array}{l}\text { Paediatric } \\
\text { oncology } \\
\text { outpatient clinics } \\
\& \text { inpatient } \\
\text { admissions }\end{array}$ & $\begin{array}{l}\text { Anthropological } \\
\text { observation study, } \\
\text { over } 9 \text { months. } \\
\text { Modified form of } \\
\text { play therapy with } \\
\text { children to allow } \\
\text { children to reflect } \\
\text { on their own } \\
\text { behaviour, in } \\
\text { addition to a } \\
\text { continued presence } \\
\text { on the ward. } \\
\text { Informal interviews } \\
\text { with staff \& parents } \\
\text { of child patients }\end{array}$ & $\begin{array}{l}\text { Anthropological } \\
\text { observation and } \\
\text { recording of children's } \\
\text { conversations and play }\end{array}$ & $\begin{array}{l}\text { Children had a greater } \\
\text { understanding of their own } \\
\text { illness \& potential death } \\
\text { than was appreciated by } \\
\text { parents \& HCPs }\end{array}$ & USA \\
\hline $\begin{array}{l}\text { Boon- } \\
\text { Yasidhi, } \\
\text { Naiwatanaku } \\
\text { l et al. } 2016^{49}\end{array}$ & Quantitative & 320 & $\begin{array}{l}160 \\
\text { caregivers; } \\
160 \\
\text { children }\end{array}$ & $8-17$ & HIV & $\begin{array}{l}\text { Medical team; } \\
\text { HIV positive } \\
\text { children who } \\
\text { were not aware } \\
\text { of their HIV status }\end{array}$ & $\begin{array}{l}\text { Assessed } \\
\text { psychosocial } \\
\text { outcomes at } \\
\text { baseline, before } \\
\text { completion of a } 4 \\
\text { step disclosure } \\
\text { service, follow up } \\
\text { assessment at } 2 \\
\text { month \& } 6 \text { months. } \\
\text { Outcomes assessed } \\
\text { using CDI, CBCL, } \\
\text { PedsQL } \\
\end{array}$ & Disclosure status & $\begin{array}{l}\text { Small but significant } \\
\text { reduction in median } \\
\text { depression score between } \\
\text { baseline \& } 2 \& 6 \text { month } \\
\text { follow up following } \\
\text { disclosure; small but } \\
\text { significant increase in } \\
\text { quality of life \& social } \\
\text { functioning domain scores. } \\
\text { Reported behavioural } \\
\text { problems did not change } \\
\text { between time points }\end{array}$ & Thailand \\
\hline $\begin{array}{l}\text { Brown, } \\
\text { Oladokun et } \\
\text { al. } 2011^{56}\end{array}$ & Quantitative & 96 & Caregivers & $\begin{array}{l}6-14 \\
(8.8)\end{array}$ & HIV & HIV clinic & $\begin{array}{l}\text { Semi structured } \\
\text { interviews including } \\
\text { whether disclosure } \\
\text { had happened \& } \\
\text { reasons for (non) } \\
\text { disclosure. } \\
\text { Disclosure classified } \\
\text { as telling the child } \\
\text { specifically that } \\
\text { they have AIDS or a } \\
\text { viral infection called } \\
\text { HIV (caregiver } \\
\text { report) }\end{array}$ & Disclosure status & $\begin{array}{l}13.5 \% \text { of children had been } \\
\text { disclosed to at mean age of } \\
8.7 \text { years. Disclosure } \\
\text { prompted by children's } \\
\text { questions about their illness, } \\
\text { medication \& needing to } \\
\text { facilitate adherence. Main } \\
\text { reasons for non-disclosure } \\
\text { were: age of child, worries } \\
\text { of psychological impact on } \\
\text { the child \& fear that child } \\
\text { would blame parent. } 63.5 \% \\
\text { of caregivers expressed a } \\
\text { preference for disclosure by }\end{array}$ & Nigeria \\
\hline
\end{tabular}




\begin{tabular}{|c|c|c|c|c|c|c|c|c|c|c|}
\hline & & & & & & & & & $\begin{array}{l}\text { parents, while } 14.6 \% \\
\text { preferred disclosure by } \\
\text { parents \& health workers } \\
\text { together. In families where } \\
\text { disclosure had taken place, } \\
\text { caregivers for } 7 \text { of the } 11 \\
\text { children felt adherence had } \\
\text { improved }\end{array}$ & \\
\hline $\begin{array}{l}\text { Claflin and } \\
\text { Barbarin } \\
1991^{69}\end{array}$ & $\begin{array}{l}\text { Mixed } \\
\text { methods }\end{array}$ & 43 & Children & $3-18$ & $\begin{array}{l}\text { Cancer } \\
\text { (leukaemia, } \\
\text { lymphoma, } \\
\text { non CNS } \\
\text { tumour) }\end{array}$ & 2 medical team & $\begin{array}{l}\text { Semi structured } \\
\text { interviews } \\
\text { (including } \\
\text { experiences of } \\
\text { diagnosis \& } \\
\text { information shared } \\
\text { about illness, } \\
\text { treatment \& } \\
\text { prognosis, parental } \\
\text { reaction) \& likert } \\
\text { scales }\end{array}$ & $\begin{array}{l}\text { Analysis of interview } \\
\text { responses }\end{array}$ & $\begin{array}{l}60 \% \text { of children over } 9 \text { years } \\
\text { had been told they had } \\
\text { cancer; only } 2 \text { younger } \\
\text { children had been told they } \\
\text { had cancer. Children of all } \\
\text { ages reported parental } \\
\text { distress related to their } \\
\text { condition }\end{array}$ & USA \\
\hline $\begin{array}{l}\text { Clarke, } \\
\text { Davies et al. } \\
2005^{72}\end{array}$ & Quantitative & 55 & Parents & $\begin{array}{l}3-18 \\
(7.33)\end{array}$ & $\begin{array}{l}\text { ALL (4 } \\
\text { months post } \\
\text { diagnosis) }\end{array}$ & 4 medical teams & $\begin{array}{l}\text { Semi structured } \\
\text { interviews } \\
\text { (including views on } \\
\text { what to tell their } \\
\text { child \& factors } \\
\text { influencing their } \\
\text { communication } \\
\text { with child) }\end{array}$ & Thematic analysis & $\begin{array}{l}\text { Distinguished four ways } \\
\text { information conveyed by } \\
\text { parents: optimism, realism, } \\
\text { pessimism, factual. Four } \\
\text { parental communication } \\
\text { styles identified: minimal } \\
\text { information, ambiguous } \\
\text { information, factual } \\
\text { information, full } \\
\text { information. Parents } \\
\text { disclosed more detailed \& } \\
\text { honest information to older } \\
\text { children. Parents who } \\
\text { believed ALL incurable gave } \\
\text { children as little information } \\
\text { as possible. Parents who felt } \\
\text { too shocked \& unable to } \\
\text { grasp information more } \\
\text { likely to tell child as much as } \\
\text { they did understand } \\
\text { themselves }\end{array}$ & UK \\
\hline $\begin{array}{l}\text { Cluver, } \\
\text { Hodes et al. } \\
2015^{46}\end{array}$ & $\begin{array}{l}\text { Mixed } \\
\text { methods }\end{array}$ & 706 & $\begin{array}{l}684 \\
\text { adolescent } \\
\text { S on ART } \\
\text { (43 } \\
\text { participate }\end{array}$ & $10-19$ & HIV & $\begin{array}{l}39 \text { health } \\
\text { facilities traced } \\
\text { adolescents who } \\
\text { had ever initiated }\end{array}$ & $\begin{array}{l}\text { Adherence } \\
\text { measured by self- } \\
\text { report PMAQ. } \\
\text { HIV status defined } \\
\text { as knows HIV status }\end{array}$ & $\begin{array}{l}\text { Thematic analysis, } \\
\text { adherence \& disclosure } \\
\text { status }\end{array}$ & $\begin{array}{l}\text { 70\% of adolescents knew } \\
\text { their HIV positive status. } \\
\text { Knowledge of HIV status } \\
\text { was associated with higher } \\
\text { adherence, independently }\end{array}$ & $\begin{array}{l}\text { South } \\
\text { Africa }\end{array}$ \\
\hline
\end{tabular}




\begin{tabular}{|c|c|c|c|c|c|c|c|c|c|c|}
\hline & & & $\begin{array}{l}\mathrm{d} \text { in } \\
\text { qualitative } \\
\text { study); } 22 \\
\text { caregivers; } \\
\text { HCPs } \\
\text { (unspecifie } \\
\text { d number) }\end{array}$ & & & $\begin{array}{l}\text { ART to their } \\
\text { communities }\end{array}$ & $\begin{array}{l}\text { or does not know } \\
\text { HIV status based on } \\
\text { self-report }\end{array}$ & & $\begin{array}{l}\text { of all cofactors. Among } \\
\text { perinatally infected } \\
\text { adolescents who knew their } \\
\text { status ( } n=362 \text { ), disclosure } \\
\text { prior to age } 12 \text { was } \\
\text { associated with higher } \\
\text { adherence. HCPs reported } \\
\text { that disclosure was } \\
\text { beneficial in reducing } \\
\text { adolescents' perception of } \\
\text { deception. }\end{array}$ & \\
\hline $\begin{array}{l}\text { Coyne, } \\
\text { Amory et al. } \\
2016^{77}\end{array}$ & Qualitative & 82 & $\begin{array}{l}20 \\
\text { children; } \\
22 \text { parents; } \\
40 \mathrm{HCPs}\end{array}$ & $7-16$ & $\begin{array}{l}\text { Cancer } \\
\text { (leukaemia, } \\
\text { cancer of } \\
\text { CNS, } \\
\text { sarcomas, } \\
\text { lymphomas) }\end{array}$ & $\begin{array}{l}\text { Inpatient } \\
\text { children's cancer } \\
\text { unit }\end{array}$ & $\begin{array}{l}\text { Semi structured } \\
\text { interviews including } \\
\text { experiences, views } \\
\text { \& preferences of } \\
\text { information sharing } \\
\& \text { child involvement }\end{array}$ & $\begin{array}{l}\text { Constant comparative } \\
\text { procedure from } \\
\text { grounded theory }\end{array}$ & $\begin{array}{l}\text { Professionals advocated } \\
\text { open \& honest approach to } \\
\text { information sharing; HCPs } \\
\text { preferred to tell parents } \\
\text { everything in order to fully } \\
\text { include them in all } \\
\text { information \& treatment } \\
\text { plans for their child. Some } \\
\text { differences within HCP } \\
\text { group in terms of how much } \\
\text { information was shared with } \\
\text { children \& how. HCPs } \\
\text { reported tailoring } \\
\text { information to child's } \\
\text { personality, cognitive ability, } \\
\text { maturity \& age. Used clinical } \\
\text { experience to gauge a } \\
\text { child's understanding \& } \\
\text { ability to cope with } \\
\text { information. Parents wanted } \\
\text { to manage how \& when } \\
\text { information shared with } \\
\text { their children. Some parents } \\
\text { felt information would } \\
\text { negatively impact on their } \\
\text { child's hope \& spirit \& } \\
\text { wanted to protect their } \\
\text { child. Some tension } \\
\text { between HCPs \& parents } \\
\text { about extent to which } \\
\text { parents 'filter' \& interpret } \\
\text { information. Children } \\
\text { wanted to be included in } \\
\text { information-sharing so they }\end{array}$ & Ireland \\
\hline
\end{tabular}




\begin{tabular}{|c|c|c|c|c|c|c|c|c|c|c|}
\hline & & & & & & & & & $\begin{array}{l}\text { were kept informed \& felt } \\
\text { prepared. Children valued } \\
\text { their parents' role as } \\
\text { interpreters of information, } \\
\text { advocates, filters \& } \\
\text { communication buffers. } \\
\text { Authors conclude HCPs need } \\
\text { to be open minded, flexible } \\
\text { and sensitive about familial } \\
\text { preference for information- } \\
\text { sharing strategies }\end{array}$ & \\
\hline $\begin{array}{l}\text { Dunsmore } \\
\text { and Quine } \\
1995^{94}\end{array}$ & Quantitative & 51 & $\begin{array}{l}\text { Children \& } \\
\text { young } \\
\text { adults }\end{array}$ & $12-24$ & $\begin{array}{l}\text { Cancer (ALL, } \\
\text { CNS tumours } \\
\& \text { range of } \\
\text { other } \\
\text { cancers). } 72 \% \\
\text { in remission, } \\
20 \% \\
\text { receiving } \\
\text { active } \\
\text { treatment, } \\
8 \% \text { in relapse } \\
\text { but no } \\
\text { treatment. }\end{array}$ & $\begin{array}{l}\text { Peer support } \\
\text { group for cancer } \\
\text { patients \& } \\
\text { siblings }\end{array}$ & $\begin{array}{l}42 \text { item self- } \\
\text { administered } \\
\text { questionnaire } \\
\text { including } \\
\text { informational \& } \\
\text { psychosocial needs } \\
\text { \& preferences }\end{array}$ & $\begin{array}{l}\text { Content analysis \& } \\
\text { coding of questionnaire } \\
\text { responses }\end{array}$ & $\begin{array}{l}\text { Participants wanted to be } \\
\text { more informed about their } \\
\text { illness \& its implications \& } \\
\text { involved in treatment } \\
\text { decisions. Almost all wanted } \\
\text { to be informed about 'bad } \\
\text { news'. Participants reported } \\
\text { communication was } \\
\text { facilitated by ability to } \\
\text { listen, genuine concern, } \\
\text { professional expertise \& } \\
\text { honesty. Study reports } \\
\text { preferences about where \& } \\
\text { how information is } \\
\text { communicated, \& from } \\
\text { whom they would like this } \\
\text { information. Study } \\
\text { highlights importance of a } \\
\text { peer group who also have } \\
\text { had experience of cancer }\end{array}$ & Australia \\
\hline $\begin{array}{l}\text { El Malla, } \\
\text { Kreicbergs et } \\
\text { al. } 2013^{63}\end{array}$ & Quantitative & 304 & Parents & $\begin{array}{l}\text { Not } \\
\text { reported }\end{array}$ & Cancer & $\begin{array}{l}\text { Child's medical } \\
\text { team }\end{array}$ & $\begin{array}{l}\text { Questionnaires } \\
\text { developed by } \\
\text { research team at } \\
\text { two different } \\
\text { treatment times. } \\
\text { Topics included } \\
\text { extent \& manner } \\
\text { information } \\
\text { provided about } \\
\text { disease, } \\
\text { communication } \\
\text { (interpersonal style } \\
\text { of HCP \& ability for } \\
\text { patient \& family to } \\
\text { express thoughts \& }\end{array}$ & Questionnaire & $\begin{array}{l}\text { Parental trust in medical } \\
\text { team associated with } \\
\text { provision of adequate } \\
\text { information, opportunity to } \\
\text { communicate with } \\
\text { physician, satisfaction with } \\
\text { conversational style of } \\
\text { physician, perception that } \\
\text { physician sensitive to } \\
\text { parent's emotional needs \& } \\
\text { that physician had met } \\
\text { parents with care at start of } \\
\text { treatment }\end{array}$ & Egypt \\
\hline
\end{tabular}




\begin{tabular}{|c|c|c|c|c|c|c|c|c|c|c|}
\hline & & & & & & & $\begin{array}{l}\text { concerns) \& trust in } \\
\text { HCP, psychosocial } \\
\text { experiences in } \\
\text { hospital }\end{array}$ & & & \\
\hline $\begin{array}{l}\text { Essig, Steiner } \\
\text { et al. 2016 }\end{array}$ & Qualitative & 54 & $\begin{array}{l}30 \mathrm{HCPs} ; \\
16 \text { former } \\
\text { adolescent } \\
\text { patients; } 8 \\
\text { parents }\end{array}$ & 13-19 & $\begin{array}{l}\text { Cancer } \\
\text { survivors } \\
\text { (disease free } \\
\text { for at least 1 } \\
\text { year) }\end{array}$ & $\begin{array}{l}\text { Paediatric } \\
\text { oncology clinics }\end{array}$ & $\begin{array}{l}11 \text { Focus groups } \\
\text { (separated by } \\
\text { category of } \\
\text { participant) } \\
\text { including prompts } \\
\text { to elicit experiences } \\
\text { of good and poor } \\
\text { communication, } \\
\text { views on how HCP } \\
\text { could communicate } \\
\text { well }\end{array}$ & $\begin{array}{l}\text { Inductive thematic } \\
\text { analysis }\end{array}$ & $\begin{array}{l}\text { Identified HCP, parent \& } \\
\text { patient perspectives on the } \\
\text { factors that make } \\
\text { communication difficult. } \\
\text { HCPs \& parents/patients } \\
\text { focused on entirely different } \\
\text { themes when discussing } \\
\text { problems with } \\
\text { communication (HCPs } \\
\text { identified adolescents being } \\
\text { withdraw \& difficult, with } \\
\text { other priorities; parents \& } \\
\text { patients highlighted specific } \\
\text { needs of adolescents, } \\
\text { experience of not being } \\
\text { taken seriously, given too } \\
\text { much or too little } \\
\text { information) All } 3 \text { groups } \\
\text { agreed communication is } \\
\text { good when doctors honest } \\
\& \text { take their time. Paper } \\
\text { identifies different } \\
\text { expectations of } \\
\text { communication from } \\
\text { doctors \& nurses (as rated } \\
\text { by Drs, nurses \& patients \& } \\
\text { parents) }\end{array}$ & $\begin{array}{l}\text { Switzerland } \\
\text {, Germany } \\
\text { \& Austria }\end{array}$ \\
\hline $\begin{array}{l}\text { Ferris, Burau } \\
\text { et al. } 2007^{60}\end{array}$ & $\begin{array}{l}\text { Retrospective } \\
\text { database } \\
\text { analysis }\end{array}$ & 325 & Children & $\begin{array}{l}5-17 \\
(13.5)\end{array}$ & HIV & $\begin{array}{l}\text { Child's medical } \\
\text { team }\end{array}$ & $\begin{array}{l}\text { Retrospective } \\
\text { database analysis. } \\
156 \text { patients were } \\
\text { disclosed to during } \\
\text { duration of study; } \\
\text { those disclosed to } \\
\text { before midpoint of } \\
\text { study categorised in } \\
\text { disclosure yes' } \\
\text { group; if in second } \\
\text { half of study, } \\
\text { categorised as } \\
\text { disclosure 'no' } \\
\text { group. }\end{array}$ & Disclosure status & $\begin{array}{l}\text { Significant associations } \\
\text { between not knowing HIV } \\
\text { diagnosis \& death, \& not } \\
\text { knowing the HIV diagnosis \& } \\
\text { disease progression }\end{array}$ & Romania \\
\hline
\end{tabular}




\begin{tabular}{|c|c|c|c|c|c|c|c|c|c|c|}
\hline & & & & & & & $\begin{array}{l}\text { CD4 cell count; } \\
\text { number of days to } \\
\text { death }\end{array}$ & & & \\
\hline $\begin{array}{l}\text { Fetzer, } \\
\text { Mupenda et } \\
\text { al. } 2011^{54}\end{array}$ & Qualitative & 40 & $\begin{array}{l}20 \\
\text { children; } \\
20 \\
\text { caregivers }\end{array}$ & $\begin{array}{l}8-17( \\
\text { median } \\
14)\end{array}$ & HIV & $\begin{array}{l}\text { Hospital HIV } \\
\text { clinic (on ART for } \\
\text { at least } 6 \text { months } \\
\& \text { had history of } \\
\text { perceived poor } \\
\text { adherence) }\end{array}$ & $\begin{array}{l}\text { Caregiver } \\
\text { confirmed child HIV } \\
\text { status. } \\
\text { Individual semi } \\
\text { structured } \\
\text { interviews } \\
\text { including adherence } \\
\text { experiences, } \\
\text { barriers/facilitators } \\
\text { to adherence \& } \\
\text { caregiver-child } \\
\text { relationship }\end{array}$ & $\begin{array}{l}\text { Qualitative content } \\
\text { analysis }\end{array}$ & $\begin{array}{l}4 \text { children aware of HIV } \\
\text { status; were more compliant } \\
\text { taking medicines \& less } \\
\text { conflict within child- } \\
\text { caregiver relationship. None } \\
\text { of the children regretted } \\
\text { knowing their HIV status \& } \\
\text { reported their knowledge } \\
\text { gave them 'strength' in } \\
\text { medication adherence. } \\
\text { Barriers to adherence } \\
\text { included children feeling } \\
\text { frustrated or fed up with } \\
\text { medication regime \& lack of } \\
\text { adult supervision to support } \\
\text { medication adherence. Lack } \\
\text { of food to take with } \\
\text { medication was a further } \\
\text { barrier. Increased } \\
\text { psychosocial support } \\
\text { commonly cited as reason } \\
\text { for good adherence, in } \\
\text { addition to beliefs about } \\
\text { helpfulness of medication. } \\
\text { Discrepancies between child } \\
\text { \& caregiver reports of } \\
\text { missed doses \& adherence }\end{array}$ & DRC \\
\hline $\begin{array}{l}\text { Fortier, } \\
\text { Batista et al. } \\
2013^{50}\end{array}$ & Quantitative & 240 & $\begin{array}{l}120 \\
\text { children; } \\
120 \\
\text { parents }\end{array}$ & 8-18 & $\begin{array}{l}\text { Cancer - 41\% } \\
\text { leukaemia; } \\
\text { other } \\
\text { diagnoses of } \\
\text { CNS cancer, } \\
\text { lymphoma, } \\
\text { sarcoma or } \\
\text { other } \\
\text { tumour. }\end{array}$ & $\begin{array}{l}\text { Child's medical } \\
\text { team }\end{array}$ & $\begin{array}{l}\text { Parents completed: } \\
\text { demographic } \\
\text { information, Peds } \\
\text { QoL. } \\
\text { Children } \\
\text { completed: PQ, } \\
\text { STAl-ch, CUIS, Peds } \\
\text { QL \& cancer } \\
\text { module }\end{array}$ & CUIS & $\begin{array}{l}\text { Illness uncertainty } \\
\text { prevalent; associated with } \\
\text { lower quality of life (both } \\
\text { general \& cancer-specific) } \\
\text { for both children diagnosed } \\
\text { with cancer \& parents. } \\
\text { Illness uncertainty } \\
\text { significant predictor of } \\
\text { general health-related \& } \\
\text { cancer-related quality of life } \\
\text { after controlling for } \\
\text { children's age, pain \& } \\
\text { anxiety. Authors } \\
\text { hypothesise that increased } \\
\text { communication around a } \\
\text { child's illness, expectation }\end{array}$ & USA \\
\hline
\end{tabular}




\begin{tabular}{|c|c|c|c|c|c|c|c|c|c|c|}
\hline & & & & & & & & & $\begin{array}{l}\text { around treatment \& } \\
\text { prognosis would decrease } \\
\text { illness uncertainty \& } \\
\text { improve psychological } \\
\text { outcomes for children }\end{array}$ & \\
\hline $\begin{array}{l}\text { Fritz, } \\
\text { Williams et } \\
\text { al. } 1988^{66}\end{array}$ & $\begin{array}{l}\text { Mixed } \\
\text { methods }\end{array}$ & 104 & $\begin{array}{l}52 \\
\text { children; } \\
52 \text { parents }\end{array}$ & $7-21$ & $\begin{array}{l}\text { Cancer (2 } \\
\text { years after } \\
\text { completion } \\
\text { of treatment) }\end{array}$ & $\begin{array}{l}\text { Child's medical } \\
\text { team }\end{array}$ & $\begin{array}{l}\text { Structured } \\
\text { interviews with } \\
\text { patient \& parents } \\
\text { (separately) } \\
\text { covering history } \\
\text { prior to illness, } \\
\text { illness \& therapy } \\
\text { course, detailed } \\
\text { review of child's life } \\
\text { since treatment } \\
\text { ended. Parent } \\
\text { interview also } \\
\text { covered personal, } \\
\text { social \& } \\
\text { occupational } \\
\text { changes in their } \\
\text { own lives } \\
\text { consequent to } \\
\text { child's cancer. } \\
\text { Depressive } \\
\text { symptomatology } \\
\text { assessed by } 2 \\
\text { independent ratings } \\
\text { of CDRS, based on } \\
\text { observation of } \\
\text { survivor \& } \\
\text { interview content. } \\
\text { Illness related data } \\
\text { based on } \\
\text { oncologists' ratings }\end{array}$ & $\begin{array}{l}\text { Psychosocial variable } \\
\text { directness of } \\
\text { communication was } \\
\text { derived from ratings of } \\
\text { interviews. This variable } \\
\text { was sum of ratings, on a } \\
5 \text { point scale of child \& } \\
\text { parents' responses to } \\
\text { questions about how } \\
\text { child handled illness in } \\
\text { school \& talked about It } \\
\text { with peers, family \& } \\
\text { strangers. } \\
\text { Survivors level of } \\
\text { comfort about talking } \\
\text { about illness was } \\
\text { summarised in index of } \\
\text { current openness, } \\
\text { which included } \\
\text { survivor's own } \\
\text { assessment, parents' } \\
\text { description \& patterns } \\
\text { observed during the } \\
\text { interview }\end{array}$ & $\begin{array}{l}\text { Direct communication } \\
\text { during treatment explained } \\
\text { a significant amount of the } \\
\text { variance in school } \\
\text { functioning, social/peer } \\
\text { interaction, activity level, } \\
\text { current openness \& global } \\
\text { adjustment. } \\
\text { Communication patterns } \\
\text { during treatment were most } \\
\text { predictive of psychosocial } \\
\text { outcome whereas indicators } \\
\text { of medical severity were } \\
\text { least predictive. Individuals } \\
\text { who were rated as well } \\
\text { adjusted used a range of } \\
\text { different coping styles, with } \\
\text { both "active approach" \& } \\
\text { avoidance being associated } \\
\text { with good outcomes }\end{array}$ & USA \\
\hline $\begin{array}{l}\text { Gibson, } \\
\text { Aldiss et al. } \\
2010^{67}\end{array}$ & Qualitative & 38 & $\begin{array}{l}\text { Children \& } \\
\text { adolescent } \\
\mathrm{s}\end{array}$ & $4-19$ & $\begin{array}{l}\text { Cancer }(47 \% \\
\text { ALL; others } \\
\text { mixed cancer } \\
\text { group) }\end{array}$ & $\begin{array}{l}\text { Cancer treatment } \\
\text { centres, posters } \\
\& \text { parent support } \\
\text { groups. Purposive } \\
\text { sampling to } \\
\text { ensure mix of } \\
\text { participants at } \\
\text { specific stages on } \\
\text { cancer journey }\end{array}$ & $\begin{array}{l}\text { Age appropriate, } \\
\text { participatory-based } \\
\text { techniques } \\
\text { including play \& } \\
\text { puppets \& the draw } \\
\& \text { write method. } \\
\text { Individual } \\
\text { interviews \& peer- } \\
\text { interviews followed } \\
\text { by group discussion, } \\
\text { focus group \& a }\end{array}$ & $\begin{array}{l}\text { Inductive thematic } \\
\text { analysis }\end{array}$ & $\begin{array}{l}\text { Younger children reported } \\
\text { being given information by } \\
\text { their parents, whereas older } \\
\text { children wanted to be } \\
\text { spoken to directly by staff. } \\
\text { Many older children felt } \\
\text { they were not given enough } \\
\text { information about illness \& } \\
\text { treatment \& wanted this } \\
\text { information directly from } \\
\text { HCP. However also }\end{array}$ & UK \\
\hline
\end{tabular}




\begin{tabular}{|c|c|c|c|c|c|c|c|c|c|c|}
\hline & & & & & & & $\begin{array}{l}\text { written task for 13- } \\
15 y r \text { old age group. } \\
\text { Questions \& } \\
\text { prompts used to } \\
\text { elicit experiences of } \\
\text { diagnosis, } \\
\text { treatment \& what } \\
\text { had been helpful }\end{array}$ & & $\begin{array}{l}\text { important for HCP to } \\
\text { recognise when adolescents } \\
\text { didn't want to talk. Results } \\
\text { used to model } \\
\text { communication within a } \\
\text { developmental context; } \\
\text { suggests children (aged 4- } \\
12 \text { years) reside in the } \\
\text { background of information } \\
\text { sharing with health } \\
\text { professionals until they gain } \\
\text { autonomy as young people } \\
\text { (around age 13). They then } \\
\text { move into the foreground, \& } \\
\text { parental role evolves to } \\
\text { support from background }\end{array}$ & \\
\hline $\begin{array}{l}\text { Goldman \& } \\
\text { Christie } \\
1993^{82}\end{array}$ & Quantitative & 22 & HCPs & $4-16$ & Cancer & $\begin{array}{l}\text { Patients treated } \\
\text { in single oncology } \\
\text { department who } \\
\text { died during } 1989\end{array}$ & $\begin{array}{l}\text { Questionnaire } \\
\text { completed by HCPs } \\
\text { after a child had } \\
\text { died regarding } \\
\text { perception of } \\
\text { child's knowledge } \\
\text { of death. Individual } \\
\text { interviews with } \\
\text { HCPs about their } \\
\text { attitude to talking } \\
\text { about death and } \\
\text { how often they } \\
\text { believed it occurred } \\
\text { in the hospital. }\end{array}$ & $\begin{array}{l}\text { HCP rated child's } \\
\text { knowledge and } \\
\text { categorised as: } \\
\text { Open conversation: } \\
\text { child discussed situation } \\
\text { openly with family } \\
\text { Acknowledged: child } \\
\text { and family knew and } \\
\text { knew each other knew, } \\
\text { but didn't discuss it } \\
\text { much } \\
\text { Prevented: death not } \\
\text { discussed by child, } \\
\text { discussion was blocked } \\
\text { by the family though } \\
\text { the nurse felt that the } \\
\text { child knew and wanted } \\
\text { to talk. } \\
\text { Not discussed: the } \\
\text { death was not discussed } \\
\text { by the child. The nurse } \\
\text { felt that the child knew } \\
\text { and chose not to talk. } \\
\text { Ignorance: the death } \\
\text { was not discussed by } \\
\text { the child. The nurse felt } \\
\text { that the child did not } \\
\text { know }\end{array}$ & $\begin{array}{l}\text { All staff members advocated } \\
\text { on open, honest approach in } \\
\text { talking to children about } \\
\text { their death but varied } \\
\text { widely and overestimated } \\
\text { how often they believed } \\
\text { discussion of the child's } \\
\text { impending death occurred. } \\
\text { Staff estimates of how many } \\
\text { parents discussed death } \\
\text { with their children suggest } \\
\text { this was relatively } \\
\text { infrequent, with only } 3 \% \\
\text { having an open discussion } \\
\text { and mutual } \\
\text { acknowledgement between } \\
\text { parent and child in a further } \\
16 \% \text {. Staff reported that this } \\
\text { mirrored pre-existing } \\
\text { patterns of honest } \\
\text { communication between } \\
\text { parents in these families. }\end{array}$ & UK \\
\hline
\end{tabular}




\begin{tabular}{|c|c|c|c|c|c|c|c|c|c|c|}
\hline & & & & & & & & $\begin{array}{l}\text { Unknown: the nurse } \\
\text { was not sure enough to } \\
\text { designate. }\end{array}$ & & \\
\hline $\begin{array}{l}\text { Haberer, } \\
\text { Cook et al. } \\
2011^{53}\end{array}$ & Quantitative & 96 & Children & $\begin{array}{l}\text { Median } \\
\text { age } 6 \\
\text { years }\end{array}$ & HIV & $\begin{array}{l}\text { Child's medical } \\
\text { team }\end{array}$ & $\begin{array}{l}\text { Disclosure status } \\
\text { not reported. } \\
\text { Adherence } \\
\text { measured by } \\
\text { electronic } \\
\text { monitoring, } \\
\text { unannounced } \\
\text { monthly home visits } \\
\text { for pill counts \& } \\
\text { caregiver report }\end{array}$ & Not measured & $\begin{array}{l}\text { Average number of missed } \\
\text { ART days lower for children } \\
\text { who knew HIV status vs } \\
\text { those who did not. } \\
\text { Adherence worse when } \\
\text { caregivers had good } \\
\text { knowledge of why their } \\
\text { child needed HIV } \\
\text { medication, but may be } \\
\text { explained by significant } \\
\text { association between } \\
\text { caregiver knowledge \& } \\
\text { another household member } \\
\text { being on ART, reflecting } \\
\text { households with greater HIV } \\
\text { burden }\end{array}$ & Zambia \\
\hline $\begin{array}{l}\text { Jacobs, Perez } \\
\text { et al. } 2015^{39}\end{array}$ & Quantitative & 34 & $\begin{array}{l}17 \\
\text { children; } \\
17 \\
\text { parents }\end{array}$ & $14-21$ & $\begin{array}{l}47 \% \\
\text { leukaemia, } \\
27 \% \text { brain } \\
\text { tumour, } 20 \% \\
\text { solid tumour, } \\
7 \% \\
\text { lymphoma }\end{array}$ & $\begin{array}{l}\text { Family centred } \\
\text { Advance care } \\
\text { planning for } \\
\text { Teens with } \\
\text { Cancer study }\end{array}$ & $\begin{array}{l}31 \text { item } \\
\text { questionnaire } \\
\text { (LACPS) } \\
\text { administered orally } \\
\text { by trained } \\
\text { facilitators }\end{array}$ & LACPS & $\begin{array}{l}75 \% \text { of adolescents believed } \\
\text { it appropriate to discuss end } \\
\text { of life decisions. } 12 \% \text { not } \\
\text { comfortable discussing } \\
\text { death. The majority of } \\
\text { adolescents preferred to } \\
\text { talk about death before } \\
\text { facing end of life decisions. } \\
\text { Understanding treatment } \\
\text { choices was important for } \\
\text { nearly all respondents. High } \\
\text { levels of congruence within } \\
\text { dyads about the importance } \\
\text { of end of life issues, } \\
\text { including "saying everything } \\
\text { I want to people in my } \\
\text { family", and understanding } \\
\text { treatment choices. } \\
\text { Adolescents wanted to be } \\
\text { told if they were dying, but } \\
\text { families were often not } \\
\text { aware of this preference. } \\
\text { Authors highlight the } \\
\text { importance of facilitated } \\
\text { discussions so that }\end{array}$ & USA \\
\hline
\end{tabular}




\begin{tabular}{|c|c|c|c|c|c|c|c|c|c|c|}
\hline & & & & & & & & & $\begin{array}{l}\text { caregivers are aware of } \\
\text { adolescents' preferences }\end{array}$ & \\
\hline $\begin{array}{l}\text { Johnston and } \\
\text { Appleby } \\
2011^{6}\end{array}$ & Quantitative & 52 & $\begin{array}{l}\text { Paediatric } \\
\text { oncologists }\end{array}$ & N/A & Oncology & $\begin{array}{l}\text { Survey of } \\
\text { pediatric } \\
\text { oncologists }\end{array}$ & $\begin{array}{l}\text { Online survey of } \\
\text { oncologists' } \\
\text { experiences \& } \\
\text { opinions of } \\
\text { breaking bad news }\end{array}$ & Survey responses & $\begin{array}{l}65 \% \text { of respondents } \\
\text { reported having at least } \\
\text { some anxiety prior to } \\
\text { disclosing bad news to } \\
\text { families \& patients. } \\
\text { Respondents most } \\
\text { concerned about how the } \\
\text { patient or family would } \\
\text { react, insufficient time \& not } \\
\text { having the answer to } \\
\text { questions the family might } \\
\text { ask. Variation in views about } \\
\text { the age at which children } \\
\text { should be included in the } \\
\text { consultation, with most } \\
\text { reporting that this should be } \\
\text { assessed on a case by case } \\
\text { basis }\end{array}$ & Canada \\
\hline $\begin{array}{l}\text { John- } \\
\text { Stewart, } \\
\text { Wariua et al. } \\
2013^{37}\end{array}$ & $\begin{array}{l}\text { Mixed } \\
\text { methods }\end{array}$ & 271 & Caregivers & $6-16$ & HIV & $\begin{array}{l}\text { Child's medical } \\
\text { team }\end{array}$ & $\begin{array}{l}\text { Disclosure classified } \\
\text { as: complete } \\
\text { (sharing HIV specific } \\
\text { information with } \\
\text { child \& naming } \\
\text { virus as HIV); partial } \\
\text { (providing child } \\
\text { with nonspecific or } \\
\text { incorrect health } \\
\text { information } \\
\text { regarding their } \\
\text { infection \& using } \\
\text { explanations of } \\
\text { other illnesses to } \\
\text { account for clinic } \\
\text { visits \& } \\
\text { medication); non } \\
\text { disclosure } \\
\text { (providing child } \\
\text { with no explanation } \\
\text { of their health } \\
\text { condition). } \\
\text { Individual semi } \\
\text { structured } \\
\text { interviews. Two } \\
\text { focus group } \\
\end{array}$ & $\begin{array}{l}\text { Disclosure status and } \\
\text { thematic analysis of } \\
\text { focus group discussions }\end{array}$ & $\begin{array}{l}79 \% \text { of caregivers reported } \\
\text { children should be disclosed } \\
\text { to, but only } 19 \% \text { of children } \\
\text { had been told diagnosis. } \\
\text { Caregivers of older children, } \\
\text { who were HIV infected \& } \\
\text { had disclosed their own HIV } \\
\text { status, or who travelled } \\
\text { frequently, were more likely } \\
\text { to have disclosed. Disclosure } \\
\text { done primarily by HCPs } \\
(52 \%) \& \text { caregivers (33\%) }\end{array}$ & Kenya \\
\hline
\end{tabular}




\begin{tabular}{|c|c|c|c|c|c|c|c|c|c|c|}
\hline & & & & & & & $\begin{array}{l}\text { discussions with } \\
\text { subset of } \\
\text { participants }\end{array}$ & & & \\
\hline $\begin{array}{l}\text { Kajubi, } \\
\text { Whyte et al. } \\
2016^{45}\end{array}$ & Qualitative & 58 & $\begin{array}{l}29 \\
\text { caregivers; } \\
29 \text { children } \\
\text { on ART }\end{array}$ & $8-17$ & HIV & $\begin{array}{l}\text { Previous cross- } \\
\text { sectional survey }\end{array}$ & $\begin{array}{l}\text { Caregivers asked if } \\
\text { they had explained } \\
\text { what medicines } \\
\text { were for; whether } \\
\text { they had informed } \\
\text { children what they } \\
\text { were suffering } \\
\text { from; if not, why } \\
\text { not \& when they } \\
\text { intended to do so. } \\
\text { Children asked } \\
\text { about reasons they } \\
\text { had been given for } \\
\text { taking their } \\
\text { medicines, who told } \\
\text { them, what \& how } \\
\text { they were told, } \\
\text { what they } \\
\text { understood about } \\
\text { illness } \\
\text { Individual } \\
\text { structured \& semi } \\
\text { structured } \\
\text { interviews. } \\
\text { Interviewers } \\
\text { completed } \\
\text { observations of } \\
\text { child's interactions } \\
\& \text { communication } \\
\text { with other family } \\
\text { members during } \\
\text { interview visit }\end{array}$ & $\begin{array}{l}\text { Content thematic } \\
\text { analysis }\end{array}$ & $\begin{array}{l}\text { Tensions between the } \\
\text { desires of caregivers \& } \\
\text { children regarding level } \\
\text { communication about } \\
\text { medicines. When caregivers } \\
\text { withheld information which } \\
\text { children wanted, children } \\
\text { used strategies including } \\
\text { medication refusal to try to } \\
\text { elicit more information, \& } \\
\text { interpreted caregivers } \\
\text { attempts to "protect" them } \\
\text { from diagnosis as deception } \\
\text { or betrayal }\end{array}$ & Uganda \\
\hline $\begin{array}{l}\text { Kreicbergs, } \\
\text { Valdimarsdot } \\
\text { tir et al. } \\
2004^{62}\end{array}$ & Quantitative & 449 & Parents & N/A & Cancer & $\begin{array}{l}\text { Parents in } \\
\text { Sweden who had } \\
\text { lost a child to } \\
\text { cancer between } \\
1992 \text { \& } 1997 \\
\text { directly contacted }\end{array}$ & $\begin{array}{l}\text { Postal } \\
\text { questionnaire (129 } \\
\text { questions) including } \\
\text { items relating to } \\
\text { whether parent } \\
\text { talked about death } \\
\text { with child, child's } \\
\text { awareness of death } \\
\text { and parental } \\
\text { reflection about }\end{array}$ & Questionnaire & $\begin{array}{l}\text { None of the } 147 \text { parents } \\
\text { who did not talk to their } \\
\text { child about death regretted } \\
\text { it. } 69 \text { of } 258 \text { parents who } \\
\text { didn't talk to their child } \\
\text { regretted not having done } \\
\text { so. Parents who sensed their } \\
\text { child was aware of } \\
\text { impending death more } \\
\text { often later regretted not }\end{array}$ & Sweden \\
\hline
\end{tabular}




\begin{tabular}{|c|c|c|c|c|c|c|c|c|c|c|}
\hline & & & & & & & $\begin{array}{l}\text { these decisions. } \\
\text { Current parental } \\
\text { anxiety \& } \\
\text { depression } \\
\text { assessed using a 7- } \\
\text { point visual digital } \\
\text { scale }\end{array}$ & & $\begin{array}{l}\text { having talked with their } \\
\text { child than the parents who } \\
\text { did not feel their child had } \\
\text { been aware of their } \\
\text { approaching death }\end{array}$ & \\
\hline $\begin{array}{l}\text { Last and van } \\
\text { Veldhuizen } \\
1996^{41}\end{array}$ & Quantitative & 112 & $\begin{array}{l}56 \\
\text { children; } \\
56 \\
\text { parents }\end{array}$ & $8-16$ & Cancer & $\begin{array}{l}\text { Child's medical } \\
\text { team }\end{array}$ & $\begin{array}{l}\text { Parents structured } \\
\text { interviews about } \\
\text { information they } \\
\text { had given to their } \\
\text { child. } \\
\text { Children completed } \\
\text { STAl-ch (Dutch } \\
\text { version), DDQ, DSC, } \\
\text { questionnaire } \\
\text { about sources of } \\
\text { information \& ease } \\
\text { of access to } \\
\text { information }\end{array}$ & $\begin{array}{l}\text { 'Information about } \\
\text { diagnosis' subscale: } 5 \\
\text { items re seriousness, } \\
\text { duration, medical } \\
\text { terminology (tumour, } \\
\text { growth, leukaemia), the } \\
\text { term cancer \& the } \\
\text { possibility of a relapse } \\
\text { or recurrence. } \\
\text { 'Information about } \\
\text { prognosis' subscale : } 2 \\
\text { items about possibility } \\
\text { child will not get better } \\
\& \text { possibility that child } \\
\text { will die of the disease }\end{array}$ & $\begin{array}{l}\text { Children who received open } \\
\text { information about their } \\
\text { diagnosis \& prognosis at the } \\
\text { initial stage of the disease } \\
\text { showed significantly less } \\
\text { anxiety \& depression } 3 \\
\text { months- } 3 \text { years later. } \\
\text { Two thirds of children } \\
\text { wanted to know everything } \\
\text { about their disease \& one } \\
\text { third as little as possible. A } \\
\text { quarter of children were } \\
\text { ambivalent about what they } \\
\text { wanted to know \& } \\
\text { answered questions } \\
\text { inconsistently, which } \\
\text { authors conclude reflects } \\
\text { conflict about what children } \\
\text { want to know }\end{array}$ & $\begin{array}{l}\text { Netherland } \\
\mathrm{s}\end{array}$ \\
\hline $\begin{array}{l}\text { Lester, } \\
\text { Chesney et } \\
\text { al. } 2002^{44}\end{array}$ & $\begin{array}{l}\text { Mixed } \\
\text { methods }\end{array}$ & 100 & $\begin{array}{l}49 \\
\text { caregivers; } \\
51 \text { children }\end{array}$ & 4 \& older & HIV & $\begin{array}{l}\text { Child's medical } \\
\text { team }\end{array}$ & $\begin{array}{l}\text { Interviews with } \\
\text { parents. } \\
\text { Parent completed } \\
\text { measures; BASC; } \\
\text { LEQ, FRI, SSQ. } \\
\text { Children measures; } \\
\text { WPPSI-R/ WISC-R } \\
\text { Children over 8 } \\
\text { completed BASC. } \\
\text { Disclosure classified } \\
\text { as: no (HIV) } \\
\text { disclosure (range of } \\
\text { information from } \\
\text { nothing to } \\
\text { information about } \\
\text { child's specific } \\
\text { discrete } \\
\text { infection/illness but } \\
\text { without } \\
\text { information about }\end{array}$ & Disclosure status & $\begin{array}{l}\text { An earlier age of disclosure } \\
\text { associated with higher child } \\
\text { IQ \& more family } \\
\text { expressiveness. Factors } \\
\text { associated with increased } \\
\text { parental anxiety are HIV } \\
\text { disclosure, other major life } \\
\text { events, more frequent } \\
\text { medication \& child age }\end{array}$ & USA \\
\hline
\end{tabular}




\begin{tabular}{|c|c|c|c|c|c|c|c|c|c|c|}
\hline & & & & & & & $\begin{array}{l}\text { HIV or AIDS); HIV } \\
\text { disclosure } \\
\text { (information that } \\
\text { child had HIV or } \\
\text { AIDS diagnosis ) }\end{array}$ & & & \\
\hline $\begin{array}{l}\text { Levenson, } \\
\text { Pfefferbaum } \\
\text { et al. } 1982^{96}\end{array}$ & Quantitative & 63 & $\begin{array}{l}\text { Adolescent } \\
\mathrm{s}\end{array}$ & $\begin{array}{l}11-20 \\
(15.8)\end{array}$ & 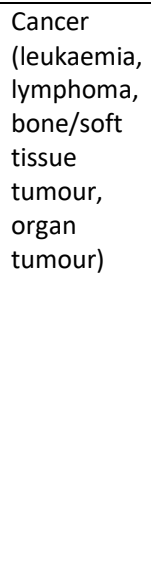 & $\begin{array}{l}\text { Child's medical } \\
\text { team }\end{array}$ & $\begin{array}{l}\text { Questionnaire } \\
\text { developed by study } \\
\text { team including } \\
\text { items relating to } \\
\text { participant report } \\
\text { of current \& } \\
\text { preferred sources } \\
\text { of information; } \\
\text { preferences for } \\
\text { receiving } \\
\text { information }\end{array}$ & Questionnaire & $\begin{array}{l}\text { Adolescents preferred } \\
\text { information from HCP, with } \\
\text { most wanting their parents } \\
\text { included in discussions. } \\
\text { Older adolescents wanted } \\
\text { information through group } \\
\text { discussions with similarly } \\
\text { aged patients. New patients } \\
\text { \& those in relapse least } \\
\text { receptive to additional } \\
\text { information, tended to rely } \\
\text { on parents rather than HCP. } \\
\text { Hispanic patients' } \\
\text { information needs poorly } \\
\text { met; alternative ways of } \\
\text { communication must be } \\
\text { considered }\end{array}$ & USA \\
\hline $\begin{array}{l}\text { Lorenz, } \\
\text { Grant et al. } \\
2016^{70}\end{array}$ & Qualitative & 28 & Caregivers & $0-14$ & HIV & $\begin{array}{l}\text { Routine clinic } \\
\text { visits, \& had to } \\
\text { have least one } \\
\text { HIV-positive child } \\
\text { who had been } \\
\text { told their } \\
\text { diagnosis \& was } \\
\text { receiving ARTs }\end{array}$ & $\begin{array}{l}\text { Semi structured } \\
\text { interviews including } \\
\text { experiences \& } \\
\text { attitudes around } \\
\text { HIV testing \& } \\
\text { disclosure to child }\end{array}$ & Thematic analysis & $\begin{array}{l}\text { Majority of children were } \\
\text { informed of HIV status } \\
\text { between the ages of 5-9 } \\
\text { (mean age }=7 \text { ) all caregivers } \\
\text { felt that a child who knew } \\
\text { their HIV status would have } \\
\text { a good attitude towards } \\
\text { their medications. Nearly } \\
\text { half had initially told the } \\
\text { child they were sick with a } \\
\text { disease other than HIV, } \\
\text { citing concerns that the } \\
\text { child was too young or } \\
\text { unable to understand about } \\
\text { HIV. Following disclosure, } \\
\text { many caregivers were } \\
\text { concerned about whether } \\
\text { the child understood; this } \\
\text { occurred across the full } \\
\text { range of ages of disclosure. } \\
\text { Caregivers expressed } \\
\text { concerns about the } \\
\text { psychological consequences } \\
\text { of disclosure, causing }\end{array}$ & Uganda \\
\hline
\end{tabular}




\begin{tabular}{|c|c|c|c|c|c|c|c|c|c|c|}
\hline & & & & & & & & & $\begin{array}{l}\text { children feel that their life } \\
\text { was" without hope" }\end{array}$ & \\
\hline $\begin{array}{l}\text { Mack, Wolfe } \\
\text { et al. } 2006^{98}\end{array}$ & Quantitative & 214 & $\begin{array}{l}194 \\
\text { parents; } 20 \\
\text { HCPs }\end{array}$ & $0.2-17.9$ & Cancer & $\begin{array}{l}\text { Cancer Institute \& } \\
\text { Children's } \\
\text { Hospital ( } 30 \text { days } \\
\& 1 \text { year from } \\
\text { date of cancer } \\
\text { diagnosis) }\end{array}$ & $\begin{array}{l}\text { 106-item parent } \\
\text { questionnaire (63 } \\
\text { previously validated } \\
\text { questions). } \\
\text { Information } \\
\text { preferences } \\
\text { assessed using } \\
\text { items from ISQ \& } \\
\text { INQ. } \\
\text { Communication } \\
\text { process \& trust in } \\
\text { HCPs assessed using } \\
\text { items from Picker } \\
\text { Survey and TIP }\end{array}$ & $\begin{array}{l}\text { Parents were asked if an } \\
\text { oncologist had ever } \\
\text { discussed their child's } \\
\text { prognosis \& whether } \\
\text { this was expressed } \\
\text { quantitatively. } \\
\text { Prognosis was defined } \\
\text { as whether child will be } \\
\text { cured of cancer, life } \\
\text { expectancy, the kind of } \\
\text { life child can expect. } \\
\text { Items from Picker } \\
\text { survey to measure } \\
\text { communication process }\end{array}$ & $\begin{array}{l}\text { Almost all parents wanted } \\
\text { as much information as } \\
\text { possible about diagnosis, } \\
\text { treatment \& prognosis. } 36 \% \\
\text { of parents found prognostic } \\
\text { information extremely or } \\
\text { very upsetting, but these } \\
\text { parents still reported } \\
\text { prognostic information was } \\
\text { important. Parents were } \\
\text { more likely to want } \\
\text { additional information if } \\
\text { they found information } \\
\text { about prognosis to be } \\
\text { upsetting. No evidence } \\
\text { prognostic information had } \\
\text { a negative impact on } \\
\text { parents' sense of hope }\end{array}$ & USA \\
\hline $\begin{array}{l}\text { Mellins, } \\
\text { Brackis-Cott } \\
\text { et al. } 2002^{47}\end{array}$ & Quantitative & 154 & $\begin{array}{l}77 \\
\text { caregivers; } \\
77 \text { children }\end{array}$ & 3-13 (8) & HIV & HIV clinics & $\begin{array}{l}\text { Caregiver rated } \\
\text { child's knowledge } \\
\text { of HIV status: } \\
\text { definitely no; } \\
\text { probably no; } \\
\text { probably yes; } \\
\text { definitely yes. } \\
\text { Caregiver: Semi } \\
\text { structured } \\
\text { interviews about } \\
\text { child's knowledge \& } \\
\text { experience of } \\
\text { disclosure; CBCL, } \\
\text { PCRI, } \\
\text { STAI, BDI. } \\
\text { Children: semi } \\
\text { structured } \\
\text { interviews about } \\
\text { experience \& } \\
\text { emotional response } \\
\text { to disclosure CDI, } \\
\text { STAl }\end{array}$ & $\begin{array}{l}\text { Disclosure status; } \\
\text { communication } \\
\text { subscale of PCRI }\end{array}$ & $\begin{array}{l}28 \% \text { of children scored in } \\
\text { clinical range on CBCL \& } 22 \% \\
\text { within the clinical range for } \\
\text { depression. } 30 \% \text { of children } \\
\text { 'definitely' or 'probably' } \\
\text { knew their HIV status \& had } \\
\text { been told by their caregiver } \\
\text { at an average age of } 7 \text { years. } \\
\text { Knowledge of HIV status did } \\
\text { not result in increased } \\
\text { mental health problems. } \\
\text { Child knowledge of HIV } \\
\text { status was not associated } \\
\text { with caregiver education, } \\
\text { biological vs adoptive } \\
\text { caregiving, PCRI or other } \\
\text { socio-demographic variables }\end{array}$ & USA \\
\hline $\begin{array}{l}\text { Menon, } \\
\text { Glazebrook } \\
\text { et al. } 2007^{43}\end{array}$ & $\begin{array}{l}\text { Quantitative } \\
\& \text { sub group } \\
\text { completed a }\end{array}$ & 254 & $\begin{array}{l}127 \\
\text { adolescent }\end{array}$ & $\begin{array}{l}11-15 \\
(12.4)\end{array}$ & & HIV clinics & $\begin{array}{l}\text { Disclosure criteria } \\
\text { not reported but } \\
\text { categorised as }\end{array}$ & $\begin{array}{l}\text { Disclosure status and } \\
\text { adolescent self-reported } \\
\text { health problems }\end{array}$ & $\begin{array}{l}\text { Compared to UK norms, } \\
\text { participants had increased } \\
\text { mental health problems }\end{array}$ & Zambia \\
\hline
\end{tabular}




\begin{tabular}{|c|c|c|c|c|c|c|c|c|c|c|}
\hline & $\begin{array}{l}\text { semi } \\
\text { structured } \\
\text { interview }\end{array}$ & & $\begin{array}{l}\text { s; } 127 \\
\text { caregivers }\end{array}$ & & & & $\begin{array}{l}\text { disclosed, not } \\
\text { disclosed or } \\
\text { disclosure status } \\
\text { unclear. } \\
\text { Adolescents: SDQ; } \\
\text { subset ( } \mathrm{n}=38 \text { ) } \\
\text { interviewed about } \\
\text { their views on } \\
\text { attending a peer } \\
\text { support group } \\
\text { Caregivers: SDQ }\end{array}$ & & $\begin{array}{l}\text { (although this in part may } \\
\text { reflect the absence of } \\
\text { culturally appropriate } \\
\text { normative data). } 37.8 \% \text { of } \\
\text { adolescents had had their } \\
\text { HIV status disclosed. } \\
\text { Participants who had not } \\
\text { had their HIV status } \\
\text { disclosed were more likely } \\
\text { to score in the abnormal } \\
\text { range of the emotional } \\
\text { difficulties subscale. } \\
\text { Children were in favour of } \\
\text { attending a support group } \\
\text { with peers }\end{array}$ & \\
\hline $\begin{array}{l}\text { Merzel, } \\
\text { VanDevanter } \\
\text { et al. } 2008^{101}\end{array}$ & Qualitative & 14 & Caregivers & $10-16$ & HIV & $\begin{array}{l}\text { Purposeful } \\
\text { sampling of } \\
\text { Northern } \\
\text { Manhattan } \\
\text { Adherence } \\
\text { Initiative }\end{array}$ & $\begin{array}{l}\text { Adherence defined } \\
\text { as: complete } \\
\text { adherence to the } \\
\text { regimen during past } \\
2 \text { weeks based on } \\
\text { client self-report } \\
\text { and confirmation of } \\
\text { strict adherence } \\
\text { during interview. } \\
\text { Semi structured } \\
\text { interviews including } \\
\text { communication, } \\
\text { experience \& } \\
\text { attitude to } \\
\text { healthcare/HCP }\end{array}$ & $\begin{array}{l}\text { Inductive thematic } \\
\text { analysis }\end{array}$ & $\begin{array}{l}\text { Caregivers report positive } \\
\text { effects of disclosure on } \\
\text { motivating child to adhere } \\
\text { to medication regimen, but } \\
\text { most beneficial for children } \\
\text { who were already } \\
\text { cooperative or just } \\
\text { beginning to question } \\
\text { regimen. Disclosure not a } \\
\text { strong adherence motivator } \\
\text { for children who were } \\
\text { described by caregivers as } \\
\text { openly resisting medication; } \\
\text { most aware of HIV status \& } \\
\text { parents reported no positive } \\
\text { benefits of disclosure on } \\
\text { adherence. } \\
\text { Only } 1 \text { caregiver said they } \\
\text { regretted telling the child }\end{array}$ & USA \\
\hline $\begin{array}{l}\text { Moodley, } \\
\text { Myer et al. } \\
2006^{102}\end{array}$ & Quantitative & 174 & Caregivers & $\begin{array}{l}0.4-11 \\
\text { (median } \\
3.3 \text { ) }\end{array}$ & HIV & HIV clinic & $\begin{array}{l}\text { Disclosure defined } \\
\text { as caregiver } \\
\text { reported discussion } \\
\text { of HIV with child. } \\
\text { Semi structured } \\
\text { interviews, } \\
\text { questionnaire } \\
\text { including open- } \\
\text { ended questions } \\
\text { about experiences } \\
\text { or preferences of } \\
\text { disclosure }\end{array}$ & $\begin{array}{l}\text { Disclosure status. } \\
\text { Descriptive analysis of } \\
\text { open ended } \\
\text { questionnaires and } \\
\text { interview }\end{array}$ & $\begin{array}{l}9 \% \text { of caregivers had spoken } \\
\text { to child about HIV status } \\
\text { (mean age }=8.1 \text { years); low } \\
\text { rate of disclosure may } \\
\text { reflect the young median } \\
\text { age of children in the study. } \\
\text { Of the caregivers who were } \\
\text { also HIV-positive ( } 73 \% \text { of the } \\
\text { overall sample), those who } \\
\text { had disclosed their status to } \\
\text { child were more than } 7 \\
\text { times more likely to have }\end{array}$ & $\begin{array}{l}\text { South } \\
\text { Africa }\end{array}$ \\
\hline
\end{tabular}




\begin{tabular}{|c|c|c|c|c|c|c|c|c|c|c|}
\hline & & & & & & & & & $\begin{array}{l}\text { talked to the child about the } \\
\text { child's HIV status. Reasons } \\
\text { for disclosure included that } \\
\text { the child has a right to } \\
\text { know, reasons relating to } \\
\text { the child's mental health, \& } \\
\text { reasons relating to } \\
\text { medication. Reasons for } \\
\text { non-disclosure concerned } \\
\text { fear that the child would tell } \\
\text { others. Twelve-years given } \\
\text { as the median preferred age } \\
\text { for telling child they have } \\
\text { HIV. Most caregivers (83\%) } \\
\text { reported best person to } \\
\text { disclose would be the } \\
\text { primary caregiver, although } \\
16 \% \text { would prefer a HCP to } \\
\text { disclose }\end{array}$ & \\
\hline $\begin{array}{l}\text { Myer, } \\
\text { Moodley et } \\
\text { al 200699 }\end{array}$ & Qualitative & 40 & HCPs & & HIV & HIV clinic & $\begin{array}{l}\text { Semi structured } \\
\text { interviews exploring } \\
\text { attitudes and } \\
\text { experiences around } \\
\text { discussing HV with } \\
\text { infected children }\end{array}$ & $\begin{array}{l}\text { Thematic analysis of } \\
\text { qualitative interviews }\end{array}$ & $\begin{array}{l}\text { Most providers felt the } \\
\text { optimal age for general } \\
\text { discussions about an HIV + } \\
\text { child's health should start } \\
\text { around age } 6, \text { but that } \\
\text { specific discussions about } \\
\text { HIV should be delayed until } \\
\text { a median of } 10 \text { years. Most } \\
\text { felt that caregivers should } \\
\text { lead these discussions, but } \\
\text { acknowledged that } \\
\text { caregivers need support } \\
\text { from HCPs. }\end{array}$ & $\begin{array}{l}\text { South } \\
\text { Africa }\end{array}$ \\
\hline $\begin{array}{l}\text { Oberdorfer, } \\
\text { Puthanakit et } \\
\text { al. 2006 }\end{array}$ & Quantitative & 103 & Caregivers & $\begin{array}{l}6-16 \\
(9.5)\end{array}$ & HIV & Hospital clinics & $\begin{array}{l}\text { Cross sectional } \\
\text { study using semi } \\
\text { structured } \\
\text { questionnaire } \\
\text { including items } \\
\text { relating to rationale } \\
\text { \& experience of } \\
\text { (non) disclosure to } \\
\text { child. Disclosure } \\
\text { defined as } \\
\text { caregiver's } \\
\text { perception of } \\
\text { having told child } \\
\text { about HIV }\end{array}$ & Disclosure status & $\begin{array}{l}30.1 \% \text { of children knew their } \\
\text { HIV status (although } 47.1 \% \\
\text { of caregivers did not use the } \\
\text { words HIV or AIDS). Mean } \\
\text { age of disclosure } 9.2 \text { years. } \\
\text { Reasons for disclosure } \\
\text { included illness, HAART } \\
\text { adherence \& discrimination } \\
\text { from school. Reasons } \\
\text { against disclosure included } \\
\text { fear of psychological } \\
\text { consequences, child too } \\
\text { young, \& discrimination }\end{array}$ & Thailand \\
\hline
\end{tabular}




\begin{tabular}{|c|c|c|c|c|c|c|c|c|c|c|}
\hline & & & & & & & $\begin{array}{l}\text { diagnosis. } \\
\text { Disclosure did not } \\
\text { require using words } \\
\text { HIV or AIDS. } \\
\text { 'Knowing' group } \\
\text { defined as children } \\
\text { whose caregivers } \\
\text { perceived child } \\
\text { knew HIV/AIDS } \\
\text { diagnosis; 'Non } \\
\text { Knowing' group of } \\
\text { children perceived } \\
\text { by caregivers to be } \\
\text { unaware of } \\
\text { diagnosis. }\end{array}$ & & & \\
\hline $\begin{array}{l}\text { Rodriguez, } \\
\text { Dunn et al. } \\
2013^{81}\end{array}$ & Quantitative & 188 & $\begin{array}{l}94 \\
\text { mothers; } \\
94 \text { children }\end{array}$ & $\begin{array}{l}5-18 \\
(10.4)\end{array}$ & Cancer & Hospital clinic & $\begin{array}{l}\text { Video-taped } \\
\text { observation of } \\
\text { mothers-child } \\
\text { dyads talking about } \\
\text { child's cancer. } \\
\text { Mothers: BDI-II }\end{array}$ & $\begin{array}{l}\text { Mother-child } \\
\text { communication coded } \\
\text { at macro (IFIRS) \& micro } \\
\text { level (CCS) }\end{array}$ & $\begin{array}{l}\text { Higher symptoms of } \\
\text { depression were associated } \\
\text { with lower positive } \\
\text { communication \& higher } \\
\text { negative communication } \\
\text { between mothers \& their } \\
\text { children }\end{array}$ & USA \\
\hline $\begin{array}{l}\text { Roscigno, } \\
\text { Grant et al. } \\
2013^{97}\end{array}$ & Qualitative & 29 & Parents & $\begin{array}{l}12-20 \\
(16)\end{array}$ & $\begin{array}{l}\text { Severe } \\
\text { traumatic } \\
\text { brain injury }\end{array}$ & $\begin{array}{l}\text { Early acute care } \\
\text { locations (part of } \\
\text { a larger study not } \\
\text { specified) }\end{array}$ & $\begin{array}{l}\text { Semi structured } \\
\text { interviews about } \\
\text { experiences from } \\
\text { time of child's } \\
\text { injury to time of } \\
\text { interview, including } \\
\text { reported doctor- } \\
\text { parent } \\
\text { communication }\end{array}$ & $\begin{array}{l}\text { Ethnography of } \\
\text { Speaking: discourse } \\
\text { analysis }\end{array}$ & $\begin{array}{l}\text { Parents felt HCP forgot that } \\
\text { impact of child's injuries } \\
\text { impaired parent's ability to } \\
\text { hear and assimilate } \\
\text { information \& prognosis. } \\
\text { Limited time for questions \& } \\
\text { lack of information } \\
\text { contributed to parental } \\
\text { distress and uncertainty. } \\
\text { Parents wanted clear } \\
\text { explanations \& honest } \\
\text { information, including } \\
\text { negative possibilities }\end{array}$ & USA \\
\hline $\begin{array}{l}\text { Santamaria, } \\
\text { Dolezal et al. } \\
2011^{42}\end{array}$ & Quantitative & 392 & $\begin{array}{l}196 \\
\text { caregivers; } \\
196 \\
\text { children }\end{array}$ & $\begin{array}{l}8-16 \\
(12.7)\end{array}$ & HIV & $\begin{array}{l}\text { Primary \& tertiary } \\
\text { care clinics } \\
\text { providing family- } \\
\text { centred care for } \\
\text { families affected } \\
\text { by HIV }\end{array}$ & $\begin{array}{l}\text { Disclosure coded } \\
\text { as: disclosed; not } \\
\text { disclosed based on } \\
\text { caregiver report. } \\
\text { Children: CDI; STAI; } \\
\text { SIS, questions about } \\
\text { intention to } \\
\text { disclose HIV status } \\
\text { in different }\end{array}$ & Disclosure status & $\begin{array}{l}70 \% \text { of participants had } \\
\text { been told diagnosis (range } \\
37 \% \text { of } 9-10 y \text { r olds to } 90 \% \text { of } \\
13-14 y \text { olds). Those who } \\
\text { had been aware of their } \\
\text { status for longer were more } \\
\text { likely to report that they } \\
\text { intended to disclose their } \\
\text { status to sexual partners. }\end{array}$ & USA \\
\hline
\end{tabular}




\begin{tabular}{|c|c|c|c|c|c|c|c|c|c|c|}
\hline & & & & & & & $\begin{array}{l}\text { hypothetical } \\
\text { situations } \\
\text { Caregivers: CBCL }\end{array}$ & & $\begin{array}{l}\text { Children who knew } \\
\text { diagnosis had significantly } \\
\text { lower levels of anxiety } \\
\text { compared to those who did } \\
\text { not }\end{array}$ & \\
\hline $\begin{array}{l}\text { Sharkey, } \\
\text { Lloyd et al. } \\
2016^{26}\end{array}$ & Qualitative & 30 & $\begin{array}{l}15 \text { parents; } \\
25 \text { HCPs }\end{array}$ & $5-16$ & $\begin{array}{l}\text { Paediatric } \\
\text { inpatients } \\
\text { with } \\
\text { identified } \\
\text { communicati } \\
\text { on difficulties }\end{array}$ & Paediatric wards & $\begin{array}{l}\text { Semi structured } \\
\text { interviews with } \\
\text { parents and HCPs; } \\
\text { focus groups with } \\
\text { HCPs. Topics } \\
\text { included } \\
\text { experiences of good } \\
\text { and poor practice of } \\
\text { communication } \\
\text { with children who } \\
\text { have a disability, } \\
\text { involvement of } \\
\text { parent and child in } \\
\text { decisions and } \\
\text { training needs. }\end{array}$ & Framework approach & $\begin{array}{l}\text { HCPs and parents reported } \\
\text { that time pressures often } \\
\text { restricted communication } \\
\text { with children, with } \\
\text { questions directed to } \\
\text { parents instead. Parents } \\
\text { wanted their knowledge and } \\
\text { expertise of communicating } \\
\text { with their child recognised } \\
\text { and utilised by HCPs. Both } \\
\text { HCPs and parents } \\
\text { emphasised the importance } \\
\text { of trust and rapport in } \\
\text { facilitating communication. } \\
\text { HCPs were aware of } \\
\text { communication aids but } \\
\text { these were frequently out of } \\
\text { date and rarely used. }\end{array}$ & UK \\
\hline $\begin{array}{l}\text { Sherman, } \\
\text { Bonanno et } \\
\text { al. } 2000^{61}\end{array}$ & Quantitative & 128 & $\begin{array}{l}64 \\
\text { caregivers; } \\
64 \text { children }\end{array}$ & $\begin{array}{l}8-18 \\
(11.8)\end{array}$ & $\begin{array}{l}\text { Long term } \\
\text { survivors of } \\
\text { HIV } \\
\text { (diagnosed at } \\
\text { least } 8 \text { years } \\
\text { before } \\
\text { recruitment } \\
\text { to study) \& } \\
\text { half had } \\
\text { contracted } \\
\text { HIV through } \\
\text { blood } \\
\text { transfusions } \\
\end{array}$ & Hospitals & $\begin{array}{l}\text { Child reported } \\
\text { disclosure to others } \\
\text { assessed by closed } \\
\text { question "Do your } \\
\text { friends know you } \\
\text { are HIV+?". } \\
\text { Interviews with } \\
\text { child \& caregiver } \\
\text { (separately) } \\
\text { approximately } 1 \\
\text { year apart. } \\
\text { Children: SPPC/A. } \\
\text { Caregiver: CBCL }\end{array}$ & $\begin{array}{l}\text { Child self-reported } \\
\text { disclosure status to } \\
\text { friends }\end{array}$ & $\begin{array}{l}\text { Children who had disclosed } \\
\text { their HIV status to friends } \\
\text { over the } 12 \text { month course of } \\
\text { the study had a significantly } \\
\text { larger increase in CD4\% than } \\
\text { children who had told their } \\
\text { friends prior to the study or } \\
\text { those who had not yet } \\
\text { disclosed to friends. Self- } \\
\text { disclosure did not impact on } \\
\text { child's behaviour or self- } \\
\text { concept }\end{array}$ & USA \\
\hline $\begin{array}{l}\text { van der } \\
\text { Geest, van } \\
\text { den Heuvel- } \\
\text { Eibrink et al. } \\
2015^{34}\end{array}$ & $\begin{array}{l}\text { Mixed } \\
\text { methods }\end{array}$ & 86 & Parents & $1-17$ & Cancer & $\begin{array}{l}\text { Parents who lost } \\
\text { a child to cancer } \\
\text { (2000-2004) after } \\
\text { receiving } \\
\text { treatment at } \\
\text { Children's } \\
\text { hospital }\end{array}$ & $\begin{array}{l}\text { Postal } \\
\text { Questionnaire } \\
\text { including closed } \\
\text { question about } \\
\text { whether discussions } \\
\text { about death took } \\
\text { place with child and } \\
\text { open ended } \\
\text { questions about }\end{array}$ & $\begin{array}{l}\text { Questionnaire. } \\
\text { Framework approach to } \\
\text { identifying emerging } \\
\text { themes from open } \\
\text { ended questions }\end{array}$ & $\begin{array}{l}55 \text { parents did not discuss } \\
\text { the impending death with } \\
\text { their child. A number of } \\
\text { themes identified in reasons } \\
\text { given for not talking to their } \\
\text { child: parents' inability to } \\
\text { discuss death, desire to } \\
\text { protect child, views } \\
\text { regarding talking with }\end{array}$ & $\begin{array}{l}\text { Netherland } \\
\mathrm{s}\end{array}$ \\
\hline
\end{tabular}




\begin{tabular}{|c|c|c|c|c|c|c|c|c|c|c|}
\hline & & & & & & & $\begin{array}{l}\text { how they talked to } \\
\text { child about death \& } \\
\text { their experiences of } \\
\text { (not) doing so }\end{array}$ & & $\begin{array}{l}\text { children, parents' views of } \\
\text { child characteristic, child's } \\
\text { unwillingness to discuss } \\
\text { subject, lack of opportunity, } \\
\text { child's disability. The } \\
\text { majority of parents felt } \\
\text { positive regarding their } \\
\text { decision about whether to } \\
\text { talk with their child about } \\
\text { their impending death or } \\
\text { not. Authors recommend } \\
\text { that HCPs should explore } \\
\text { with parents whether they } \\
\text { wish to talk to their child } \\
\text { about death \& identify } \\
\text { parents' reasons that form } \\
\text { the basis for their decision }\end{array}$ & \\
\hline $\begin{array}{l}\text { Vaz, Corneli } \\
\text { et al. } 2008^{40}\end{array}$ & Qualitative & 40 & $\begin{array}{l}19 \\
\text { children; } \\
21 \\
\text { caregivers }\end{array}$ & $10-21$ & HIV & $\begin{array}{l}\text { Organisations } \\
\text { providing care \& } \\
\text { support for } \\
\text { children \& } \\
\text { families living } \\
\text { with HIV }\end{array}$ & $\begin{array}{l}\text { Semi structured } \\
\text { interviews including } \\
\text { reasons for } \\
\text { disclosure, } \\
\text { anticipated and } \\
\text { actual responses to } \\
\text { disclosure } \\
\text { (caregivers); } \\
\text { disclosure } \\
\text { experiences\& } \\
\text { communication } \\
\text { about health } \\
\text { (children). } \\
\text { Disclosure classified } \\
\text { as adult caregiver } \\
\text { or HCP using HIV, } \\
\text { AIDS or (local } \\
\text { synonymous word) } \\
\text { with the child, } \\
\text { specific to child's } \\
\text { health status. Child } \\
\text { had to state they } \\
\text { had HIV, AIDS (or } \\
\text { synonymous local } \\
\text { term) during } \\
\text { screening process }\end{array}$ & $\begin{array}{l}\text { Disclosure status. } \\
\text { Qualitative content } \\
\text { analysis to identify } \\
\text { themes \& patterns }\end{array}$ & $\begin{array}{l}\text { Reasons given for disclosure } \\
\text { included child's adherence } \\
\text { to treatment regime, need } \\
\text { for child to "protect } \\
\text { themselves or stay healthy" } \\
\& \text { the child's increasing age. } \\
\text { Most caregivers used prayer } \\
\text { before disclosure; other } \\
\text { preparatory activities } \\
\text { included talking to a HCP \& } \\
\text { planning responses to } \\
\text { questions child might ask. } \\
\text { Most children were } \\
\text { surprised to learn of their } \\
\text { diagnosis but } 88 \% \text { felt it was } \\
\text { better for them to know } \\
\text { their HIV status }\end{array}$ & DRC \\
\hline $\begin{array}{l}\text { Vaz, Eng et } \\
\text { al. } 2010^{58}\end{array}$ & Qualitative & 16 & $\begin{array}{l}8 \\
\text { caregivers; } \\
8 \text { children }\end{array}$ & $8-17$ & HIV & $\begin{array}{l}\text { Targeted } \\
\text { recruitment from } \\
\text { family-centred }\end{array}$ & $\begin{array}{l}\text { Semi structured } \\
\text { interviews with } \\
\text { child (all aware of }\end{array}$ & Content analysis & $\begin{array}{l}\text { Children described limited } \\
\text { communication with their } \\
\text { HCP prior to disclosure. }\end{array}$ & $\overline{D R C}$ \\
\hline
\end{tabular}




\begin{tabular}{|c|c|c|c|c|c|c|c|c|c|c|}
\hline & & & & & & $\begin{array}{l}\text { HIV care \& } \\
\text { treatment } \\
\text { program, based } \\
\text { on program } \\
\text { staffs' existing } \\
\text { knowledge of } \\
\text { children }\end{array}$ & $\begin{array}{l}\text { HIV status) and } \\
\text { caregiver } \\
\text { (separately) } \\
\text { including } \\
\text { demographic \& } \\
\text { family } \\
\text { characteristics; } \\
\text { open questions } \\
\text { about disclosure } \\
\text { experiences, child's } \\
\text { description \& } \\
\text { opinion of } \\
\text { disclosure, } \\
\text { understanding of } \\
\text { HIV pre and post } \\
\text { disclosure }\end{array}$ & & $\begin{array}{l}\text { Received little or misleading } \\
\text { information from family } \\
\text { about illness, medication \& } \\
\text { symptoms. On disclosure, } \\
\text { children described feeling } \\
\text { sadness, but also relief. } \\
\text { Parents recounted children's } \\
\text { reactions very differently }\end{array}$ & \\
\hline $\begin{array}{l}\text { Vaz, Maman } \\
\text { et al. } 2011^{74}\end{array}$ & Quantitative & 201 & Caregivers & $5-17$ & HIV & $\begin{array}{l}\text { Paediatric HIV } \\
\text { programme }\end{array}$ & $\begin{array}{l}\text { Structured } \\
\text { interviews including } \\
\text { emotional } \\
\text { closeness between } \\
\text { child \& caregiver, } \\
\text { patterns of } \\
\text { disclosure \& } \\
\text { caregivers views of } \\
\text { disclosure \& stigma. } \\
\text { Disclosure } \\
\text { categorised as: No } \\
\text { Information } \\
\text { (questions about } \\
\text { illness/ health } \\
\text { ignored. Child told } \\
\text { to take } \\
\text { medications, attend } \\
\text { appointments \& } \\
\text { avoid certain } \\
\text { behaviours without } \\
\text { reason being given); } \\
\text { Deflecting } \\
\text { information } \\
\text { (information given } \\
\text { not true, or would } \\
\text { have to be } \\
\text { retracted at a later } \\
\text { date in order to } \\
\text { provide other } \\
\text { information, child }\end{array}$ & Disclosure category & $\begin{array}{l}\text { Nearly } 50 \% \text { provided no } \\
\text { information to child about } \\
\text { their health; } 33 \% \text { had only } \\
\text { given deflecting information } \\
\text { about the child's health. } \\
94 \% \text { of caregivers felt child } \\
\text { should be told HIV status \& } \\
\text { that they were the best } \\
\text { person to tell them } \\
\text { eventually. } 75 \% \text { had } \\
\text { considered what might } \\
\text { prompt them to disclose to } \\
\text { child. } 33 \% \text { felt no benefits to } \\
\text { telling child HIV status, citing } \\
\text { concerns about } \\
\text { psychological impact on } \\
\text { child. Cited benefits of } \\
\text { disclosure were improved } \\
\text { self-care by child, child } \\
\text { protecting themselves \& } \\
\text { others from harm }\end{array}$ & DRC \\
\hline
\end{tabular}




\begin{tabular}{|c|c|c|c|c|c|c|c|c|c|c|}
\hline & & & & & & & $\begin{array}{l}\text { told had another } \\
\text { illness; Partial } \\
\text { Information (HIV } \\
\text { not mentioned, but } \\
\text { given information } \\
\text { that could provide } \\
\text { some awareness of } \\
\text { status, eg } \\
\text { medications reduce } \\
\text { incidence of } \\
\text { symptoms, or that } \\
\text { child is prone to } \\
\text { falling ill. Child told } \\
\text { to adopt } \\
\text { preventative } \\
\text { measures to avoid } \\
\text { others getting sick); } \\
\text { Mixed Information } \\
\text { (combination of } \\
\text { truth \& deflection } \\
\text { eg sick since birth, } \\
\text { but don't have HIV) }\end{array}$ & & & \\
\hline $\begin{array}{l}\text { Vreeman, } \\
\text { Scanlon et al. } \\
2015^{91}\end{array}$ & Qualitative & 84 & $\begin{array}{l}61 \\
\text { caregivers } \\
\text { who had \& } \\
\text { had not } \\
\text { disclosed } \\
\text { to their } \\
\text { child; } 23 \\
\text { HIV } \\
\text { positive } \\
\text { children } \\
\text { who knew } \\
\text { their status }\end{array}$ & $10-16$ & HIV & $\begin{array}{l}\text { Convenience } \\
\text { sample recruited } \\
\text { from HIV clinics }\end{array}$ & $\begin{array}{l}\text { Focus group } \\
\text { discussions, } \\
\text { facilitated using } \\
\text { semi structured } \\
\text { interview guides } \\
\text { including } \\
\text { experiences \& } \\
\text { perspectives on HIV } \\
\text { disclosure }\end{array}$ & $\begin{array}{l}\text { Constant comparative } \\
\text { analysis }\end{array}$ & $\begin{array}{l}\text { Caregivers' decisions around } \\
\text { disclosure influenced by a } \\
\text { complex social environment } \\
\text { including caregiver-child } \\
\text { dyad, family members \& } \\
\text { wider social connections, } \\
\text { schools, churches \& media. } \\
\text { Caregivers and children } \\
\text { recognised stigma as a } \\
\text { barrier to disclosure. } \\
\text { Caregivers reported children } \\
\text { had some awareness of } \\
\text { their diagnosis before } \\
\text { disclosure, which made } \\
\text { disclosure more difficult as } \\
\text { didn't know how much the } \\
\text { child knew \& when to start } \\
\text { the disclosure process. } \\
\text { Conversely, children } \\
\text { generally denied knowing } \\
\text { their status before they } \\
\text { were directly told. } \\
\text { Caregivers concerned }\end{array}$ & Kenya \\
\hline
\end{tabular}




\begin{tabular}{|c|c|c|c|c|c|c|c|c|c|c|}
\hline & & & & & & & & & $\begin{array}{l}\text { disclosure would harm the } \\
\text { child psychologically, lead } \\
\text { the child to blame the } \\
\text { caregiver or disclose to } \\
\text { other people }\end{array}$ & \\
\hline $\begin{array}{l}\text { Wolfe, Klar } \\
\text { et al. } 2000^{64}\end{array}$ & Quantitative & 145 & $\begin{array}{l}103 \\
\text { parents; } 42 \\
\text { HCPs }\end{array}$ & $\begin{array}{l}10.8 \text { at } \\
\text { time of } \\
\text { death }\end{array}$ & Cancer & $\begin{array}{l}\text { Parents who lost } \\
\text { a child to cancer } \\
\text { (>1 yr previously } \\
\text { mean } 3.1 \text { yrs) } \\
\text { after receiving } \\
\text { treatment at } \\
\text { Children's } \\
\text { hospital }\end{array}$ & $\begin{array}{l}\text { Semi structured } \\
\text { interviews with } \\
\text { parents. } \\
\text { Questionnaires with } \\
\text { HCPs; medical } \\
\text { notes review. }\end{array}$ & $\begin{array}{l}\text { Categorical responses or } \\
\text { Likert scales }\end{array}$ & $\begin{array}{l}\text { There was a significant } \\
\text { discrepancy between HCPs } \\
\text { and parents' reported aware } \\
\text { of when the child entered } \\
\text { the end of life care period, } \\
\text { with HCPs documenting this } \\
\text { earlier in the illness. Smaller } \\
\text { differences were reported } \\
\text { when the child had a } \\
\text { haematological malignancy, } \\
\text { or their parents had no } \\
\text { more than a high school } \\
\text { education, or when a } \\
\text { psychosocial clinician was } \\
\text { involved in end of life care. } \\
\text { Only 49\% of parents } \\
\text { reported that their } \\
\text { understanding of no realistic } \\
\text { cure for their child came } \\
\text { from discussion with the } \\
\text { medical team. Concordance } \\
\text { between HCPs and parents' } \\
\text { recognition that there was } \\
\text { no cure for the child was } \\
\text { significantly associated with } \\
\text { earlier discussion of hospice } \\
\text { involvement, better } \\
\text { parental ratings of the } \\
\text { quality of care delivered at } \\
\text { home, earlier institution of } \\
\text { 'do not resuscitate' orders } \\
\text { and less cancer directed } \\
\text { treatment in the last month } \\
\text { of life. }\end{array}$ & USA \\
\hline $\begin{array}{l}\text { Woolley, } \\
\text { Stein et al. } \\
1989^{95}\end{array}$ & Quantitative & 70 & Parents & $1-17$ & $\begin{array}{l}\text { Cerebral } \\
\text { degenerative } \\
\text { disorder, } \\
\text { brain } \\
\text { tumour, } \\
\text { Muscopolysa }\end{array}$ & $\begin{array}{l}\text { Children's } \\
\text { Hospice }\end{array}$ & $\begin{array}{l}\text { Semi structured } \\
\text { questionnaire } \\
\text { including how } \\
\text { diagnosis } \\
\text { communicated, } \\
\text { what parent liked } \\
\end{array}$ & $\begin{array}{l}\text { Parent rating of } \\
\text { satisfaction with } \\
\text { diagnostic experience \& } \\
\text { illness information }\end{array}$ & $\begin{array}{l}\text { Parents valued an open } \\
\text { sympathetic, direct, \& } \\
\text { uninterrupted discussion of } \\
\text { the diagnosis in private. } \\
\text { Time to absorb information } \\
\text { and seek clarification from }\end{array}$ & UK \\
\hline
\end{tabular}




\begin{tabular}{|c|c|c|c|c|c|c|c|c|c|c|}
\hline & & & & & $\begin{array}{l}\text { ccharidosis, } \\
\text { neuromuscul } \\
\text { ar disease, } \\
\text { other } \\
\text { neoplasms }\end{array}$ & & $\begin{array}{l}\text { or disliked about } \\
\text { how consultation } \\
\text { managed \& } \\
\text { information } \\
\text { provide. GHQ }\end{array}$ & & $\begin{array}{l}\text { HCP was important. Parents } \\
\text { disliked evasive or } \\
\text { unsympathetic brief } \\
\text { interviews. With hindsight, } \\
\text { no parent had wanted to be } \\
\text { protected from bad news \& } \\
\text { consensus was that } \\
\text { imagining the worst was } \\
\text { worse than knowing it }\end{array}$ & \\
\hline $\begin{array}{l}\text { Woolley, } \\
\text { Stein et al } \\
1989 .{ }^{85}\end{array}$ & Quantitative & 24 & HCPs & N/A & $\begin{array}{l}\text { Cerebral } \\
\text { degenerative } \\
\text { disorder, } \\
\text { brain } \\
\text { tumour, } \\
\text { Muscopolysa } \\
\text { ccharidosis, } \\
\text { neuromuscul } \\
\text { ar disease, } \\
\text { other } \\
\text { neoplasms }\end{array}$ & $\begin{array}{l}\text { Children's } \\
\text { Hospice }\end{array}$ & $\begin{array}{l}\text { Semi structured } \\
\text { questionnaire } \\
\text { including job } \\
\text { satisfaction, factors } \\
\text { that created and } \\
\text { mitigated against } \\
\text { stress, personal } \\
\text { experiences, staff } \\
\text { support and } \\
\text { training. GHQ }\end{array}$ & $\begin{array}{l}\text { Semi structured } \\
\text { interview }\end{array}$ & $\begin{array}{l}25 \% \text { of HCPs experienced } \\
\text { high degrees of stress; these } \\
\text { HCPs had experienced a } \\
\text { recent personal } \\
\text { bereavement or had } \\
\text { previous bereavements that } \\
\text { remained raw or } \\
\text { unresolved. HCPs reported } \\
\text { feeling undermined and } \\
\text { distressed by the behaviour } \\
\text { of some families, } \\
\text { particularly when this was } \\
\text { expressed as anger or } \\
\text { criticism. Relationships } \\
\text { difficulties within the HCP } \\
\text { group were a further source } \\
\text { of stress, with the authors } \\
\text { highlighting the importance } \\
\text { of staff support systems and } \\
\text { cohesiveness. HCPs } \\
\text { frequently reported the } \\
\text { alleviation of suffering and } \\
\text { distress in others as } \\
\text { important to their job } \\
\text { satisfaction. }\end{array}$ & UK \\
\hline $\begin{array}{l}\text { Young, } \\
\text { Dixon- } \\
\text { Woods et al. } \\
2003^{76}\end{array}$ & Qualitative & 32 & $\begin{array}{l}13 \\
\text { children; } \\
19 \text { parents }\end{array}$ & 8-17 & $\begin{array}{l}\text { Cancer or } \\
\text { brain tumour }\end{array}$ & $\begin{array}{l}\text { Paediatric } \\
\text { oncology unit }\end{array}$ & $\begin{array}{l}\text { Semi structured } \\
\text { interviews about } \\
\text { experience of } \\
\text { communication } \\
\text { about cancer }\end{array}$ & $\begin{array}{l}\text { Constant comparative } \\
\text { method }\end{array}$ & $\begin{array}{l}\text { Period around diagnosis } \\
\text { important in influencing } \\
\text { patterns of communication, } \\
\text { with parents managing } \\
\text { what, when \& how children } \\
\text { told about illness. Parental } \\
\text { roles could be problematic } \\
\text { for young people, but many } \\
\text { also actively utilised their } \\
\text { parents to help manage } \\
\text { communication. } \\
\text { Communication preferences }\end{array}$ & UK \\
\hline
\end{tabular}




\begin{tabular}{|c|c|c|c|c|c|c|c|c|c|c|}
\hline & & & & & & & & & $\begin{array}{l}\text { based on personal } \\
\text { preference rather than } \\
\text { chronological age. HCPs } \\
\text { need to be aware of } \\
\text { dynamics between parents } \\
\text { and young people which } \\
\text { may lead to exclusion of } \\
\text { young people's voices \& } \\
\text { impede successful } \\
\text { relationships with HCP }\end{array}$ & \\
\hline $\begin{array}{l}\text { Young, Ward } \\
\text { et al. } 2011^{75}\end{array}$ & Qualitative & 53 & Parents & $\begin{array}{l}1-12 \\
\text { (Median } \\
4)\end{array}$ & ALL & $\begin{array}{l}\text { Six principal UK } \\
\text { treatment } \\
\text { centres }\end{array}$ & $\begin{array}{l}\text { Semi structured } \\
\text { interviews including } \\
\text { experience of } \\
\text { communication } \\
\text { during child's } \\
\text { illness, relationships } \\
\text { with HCPs \& impact } \\
\text { of illness on child }\end{array}$ & $\begin{array}{l}\text { Constant comparative } \\
\text { method \& content } \\
\text { analysis }\end{array}$ & $\begin{array}{l}\text { Parents acknowledged } \\
\text { benefits and challenges of } \\
\text { joint meetings with HCP and } \\
\text { children, including } \\
\text { concurrent demands of } \\
\text { childcare causing problems } \\
\text { concentrating on the } \\
\text { conversation, restricting } \\
\text { communication with } \\
\text { physicians \& making } \\
\text { emotional care of own child } \\
\text { difficult. Authors suggest } \\
\text { this could be addressed by } \\
\text { separate meetings with } \\
\text { parents before inclusion of } \\
\text { the child, in order to allow } \\
\text { parents time to absorb } \\
\text { information }\end{array}$ & UK \\
\hline $\begin{array}{l}\text { Zwaanswijk, } \\
\text { Tates et al. } \\
2007^{93}\end{array}$ & Qualitative & 36 & $\begin{array}{l}7 \text { children; } \\
11 \text { parents; } \\
18 \\
\text { survivors of } \\
\text { childhood } \\
\text { cancer }\end{array}$ & $8-17$ & Cancer & $\begin{array}{l}\text { Consecutive } \\
\text { inclusion in two } \\
\text { university } \\
\text { oncology wards }\end{array}$ & $\begin{array}{l}\text { Online focus groups } \\
\text { with prompts } \\
\text { regarding } \\
\text { experiences of } \\
\text { diagnostic } \\
\text { consultation, family } \\
\text { and HCP roles } \\
\text { around information } \\
\text { exchange, } \\
\text { preferences about } \\
\text { decision making }\end{array}$ & Thematic analysis & $\begin{array}{l}\text { Key aspects of interpersonal } \\
\text { communication including } \\
\text { honesty, support, need to } \\
\text { be fully informed. Young } \\
\text { patients wanted medical } \\
\text { information \& to be allowed } \\
\text { to participate in medical } \\
\text { decision making. Variations } \\
\text { in preferences between } \\
\text { participants \& sometimes } \\
\text { conflicting preferences } \\
\text { between parents \& patients. } \\
\text { Emphasises the importance } \\
\text { of idiosyncratic decisions } \\
\text { about who, what, when of } \\
\text { communication }\end{array}$ & $\begin{array}{l}\text { Netherland } \\
\mathrm{s}\end{array}$ \\
\hline
\end{tabular}




\begin{tabular}{|c|c|c|c|c|c|c|c|c|c|c|}
\hline $\begin{array}{l}\text { Zwaanswijk, } \\
\text { Tates et al. } \\
2011^{73}\end{array}$ & Quantitative & 144 & $\begin{array}{l}44 \\
\text { children; } \\
59 \text { parents; } \\
51 \\
\text { survivors of } \\
\text { childhood } \\
\text { cancer (age } \\
10-30 \text { at } \\
\text { time of } \\
\text { study) }\end{array}$ & $8-17$ & Cancer & $\begin{array}{l}\text { Consecutive } \\
\text { inclusion } \\
\text { from three } \\
\text { paediatric } \\
\text { oncology centres }\end{array}$ & $\begin{array}{l}\text { Vignettes of } \\
\text { hypothetical } \\
\text { situations in which } \\
\text { important factors } \\
\text { were systematically } \\
\text { varied were } \\
\text { presented to } \\
\text { participant } \\
\text { following an } \\
\text { experimental } \\
\text { design. Participants } \\
\text { asked to rate } \\
\text { preferences } \\
\text { regarding } \\
\text { importance of } \\
\text { affective } \\
\text { communication of } \\
\text { HCP, child's } \\
\text { involvement in } \\
\text { information } \\
\text { exchange and } \\
\text { decision-making for } \\
\text { each scenario on } \\
\text { VAS }\end{array}$ & $\begin{array}{l}\text { Preferences rated on } \\
\text { VAS }\end{array}$ & $\begin{array}{l}\text { Empathy in relationship with } \\
\text { HCP consistently rated as } \\
\text { important by participants. In } \\
\text { most situations participants } \\
\text { preferred information to be } \\
\text { given to the patient \& } \\
\text { parent simultaneously. } \\
\text { Some variation in } \\
\text { preference regarding the } \\
\text { amount of information } \\
\text { provided; mainly influenced } \\
\text { by the hypothetical patient's } \\
\text { age \& emotionality. In most } \\
\text { situations the participants } \\
\text { preferred children to } \\
\text { participate in medical } \\
\text { decision-making }\end{array}$ & $\begin{array}{l}\text { Netherland } \\
s\end{array}$ \\
\hline
\end{tabular}

ALL: Acute lymphoblastic Leukaemia

ART: Antiretroviral Therapy

BASC: Behaviour Assessment Scale for Children

BSI: Brief symptom Inventory

$\mathrm{CBCL}$ : Child Behaviour Check List

CCS: Contingency Coding System

CDI: Children Depression Inventory

CDRS: Children's Depression Rating Scale

CHLoC: Children's Health Locus of Control

CNS: Central Nervous system

CSI: Coping Strategies Inventory

CUIS: Children's Uncertainty in Illness Scale

DDQ: Dutch Depression Questionnaire

DSC: Defence Scale for Children

FACES: Family Adaptability \& Cohesion Evaluation Scale 
FRI: Family relationship Index

GHQ: General Health Questionnaire

HAART: Highly Active Antiretroviral Therapy

HCP: Healthcare Professional

IES: Impact of Events Scale

IFIRS: Iowa Family Interaction Rating Scales

INQ: Information Needs Questionnaire

ISQ: Information Styles Questionnaire

LACPS: Lyon Advance care Planning Survey - Adolescent \& Family Version

LEQ: Life Events Questionnaire

PCRI: Parent-Child Relationship Inventory

PedsQoL: Paediatric Quality of Life

PMAQ: patient medication Adherence Questionnaire

PTSDRI: Post-traumatic Stress Disorder Reaction Index

$P Q:$ Pain Questionnaire

SDQ: Strength \& Difficulties Questionnaire

SIS: Social Impact Scale

SNRDAT: Social Network Reciprocity \& Dimensionality Assessment Too

SPPC/A: Self-perception Profile for Children/Adolescents

SSQ: Sarason Social Support Questionnaire

STAI: State-Trait Anxiety Inventory

STAI-Ch: State-Trait Anxiety Inventory for Children

TIP: Trust in Physicians Scale

TSC: Trauma Symptom Checklist

VABS: Vinel \& Adaptive behaviour scales

VAS: Visual Analogue Scale

WISC: Weschler intelligence Scale for children

WPPSI: Weschler pre school \& Primary Scale of intelligence 


\section{References}

1. UNAIDS. http://www.unaids.org/en/resources/fact-sheet (accessed 5 April 2018).

2. IARC. https://www.iarc.fr/ (accessed 5 April 2018).

3. Knaul FM, Farmer PE, Krakauer EL, et al. Alleviating the access abyss in palliative care and pain relief-an imperative of universal health coverage: the Lancet Commission report. Lancet 2018; 391(10128): 1391-454.

4. Fallowfield L, Jenkins V. Communicating sad, bad, and difficult news in medicine. Lancet 2004; 363(9405): 312-9.

5. Levetown M, American Academy of Pediatrics Committee on B. Communicating with children and families: from everyday interactions to skill in conveying distressing information. Pediatrics 2008; 121(5): e1441-60.

6. Johnston DL, Appleby W. Pediatric oncologists opinions on breaking bad news. Pediatr Blood Cancer 2011; 56(3): 506.

7. Sisk BA, Bluebond-Langner M, Wiener L, Mack J, Wolfe J. Prognostic Disclosures to Children: A Historical Perspective. Pediatrics 2016; 138(3): e20161278.

8. Shields L, Zhou H, Pratt J, Taylor M, Hunter J, Pascoe E. Family-centred care for hospitalised children aged 0-12 years. Cochrane Database Syst Rev 2012; 10: CD004811.

9. Association BM. The changing face of medicine and the role of doctors in the future: Presidential project 2017, 2017.

10. Slaughter V. Young children's understanding of death. Australian Psychologist 2005; 40(3): $179-86$.

11. Schonfeld DJ. Talking with children about death. J Pediatr Health Care 1993; 7(6): 269-74.

12. Panagiotaki G, Hopkins M, Nobes G, Ward E, Griffiths D. Children's and adults' understanding of death: Cognitive, parental, and experiential influences. J Exp Child Psychol 2018; 166: 96-115.

13. Eiser C. Children's concepts of illness: Towards an alternative to the "stage" approach. Psychology \& Health 1989; .3(2): pp.

14. Su YH, Ryan-Wenger NA. Children's adjustment to parental cancer - A theoretical model development. Cancer Nurs 2007; 30(5): 362-81.

15. Sawyer SM, Azzopardi PS, Wickremarathne D, Patton GC. The age of adolescence. Lancet Child Adolesc Health 2018; 2(3): 223-8.

16. Blakemore SJ, Robbins TW. Decision-making in the adolescent brain. Nat Neurosci 2012; 15(9): 1184-91.

17. Essig S, Steiner $\mathrm{C}$, Kuehni CE, Weber H, Kiss A. Improving Communication in Adolescent Cancer Care: A Multiperspective Study. Pediatr Blood Cancer 2016; 63(8): 1423-30.

18. Davidson LL, Grigorenko EL, Boivin MJ, Rapa E, Stein A. A focus on adolescence to reduce neurological, mental health and substance-use disability. Nature 2015; 527(7578): S161-6.

19. Morgan S, Davies S, Palmer S, Plaster M. Sex, drugs, and rock ' $n$ ' roll: caring for adolescents and young adults with cancer. J Clin Oncol 2010; 28(32): 4825-30.

20. Nordmark-Lindberg I, Lindberg T. A child's experience of imminent death. Acta Paediatr Scand 1979; 68(5): 645-8.

21. Bluebond-Langner M. Worlds of dying children and their well siblings. Death Studies 1989; 13(1): 1-16.

22. Hunter SB, Smith DE. Predictors of children's understandings of death: age, cognitive ability, death experience and maternal communicative competence. Omega (Westport) 2008; 57(2): 143-62.

23. Jay SM, Green V, Johnson S, Caldwell S, Nitschke R. Differences in death concepts between children with cancer and physically healthy children. Journal of Clinical Child Psychology 1987; 16(4): 301-6.

24. Mahon MM. Children's concept of death and sibling death from trauma. J Pediatr Nurs 1993; 8(5): 335-44. 
25. Cotton CR, Range LM. Children's death concepts: Relationship to cognitive functioning, age, experience with death, fear of death, and hopelessness. Journal of Clinical Child Psychology 1990; 19(2): 123-7.

26. Sharkey S, Lloyd C, Tomlinson R, et al. Communicating with disabled children when inpatients: barriers and facilitators identified by parents and professionals in a qualitative study. Health Expect 2016; 19(3): 738-50.

27. Oulton K, Gibson F, Carr L, et al. Mapping staff perspectives towards the delivery of hospital care for children and young people with and without learning disabilities in England: a mixed methods national study. BMC Health Serv Res 2018; 18(1): 203.

28. NICE. https://www.nice.org.uk/guidance/ng61 (accessed 5 April 2018).

29. Surbone A, Ritossa C, Spagnolo AG. Evolution of truth-telling attitudes and practices in Italy. Crit Rev Oncol Hematol 2004; 52(3): 165-72.

30. Berg A. Ancestor reverence and mental health in South Africa. Transcult Psychiatry 2003; 40(2): 194-207.

31. Wiener L, McConnell DG, Latella L, Ludi E. Cultural and religious considerations in pediatric palliative care. Palliat Support Care 2013; 11(1): 47-67.

32. SCOPE. https://www.scope.org.uk/Support/Professional/Sharing-Diagnosis (accessed 27 February 2017).

33. Adduci A, Jankovic M, Strazzer S, Massimino M, Clerici C, Poggi G. Parent-child communication and psychological adjustment in children with a brain tumor. Pediatr Blood Cancer 2012; 59(2): 2904.

34. van der Geest IMM, van den Heuvel-Eibrink MM, van Vliet LM, et al. Talking about death with children with incurable cancer: Perspectives from parents. The Journal of Pediatrics 2015; 167(6): 1320-6.

35. Britto C, Mehta K, Thomas R, Shet A. Prevalence and Correlates of HIV Disclosure Among Children and Adolescents in Low- and Middle-Income Countries: A Systematic Review. J Dev Behav Pediatr 2016; 37(6): 496-505.

36. Pinzon-Iregui MC, Beck-Sague CM, Malow RM. Disclosure of their HIV status to infected children: a review of the literature. J Trop Pediatr 2013; 59(2): 84-9.

37. John-Stewart GC, Wariua G, Beima-Sofie KM, et al. Prevalence, perceptions, and correlates of pediatric HIV disclosure in an HIV treatment program in Kenya. AIDS Care 2013; 25(9): 1067-76.

38. Bluebond Langner M. The private worlds of dying children. Princeton, N.J: Princeton University Press; 1978.

39. Jacobs S, Perez J, Cheng YI, Sill A, Wang J, Lyon ME. Adolescent end of life preferences and congruence with their parents' preferences: results of a survey of adolescents with cancer. Pediatr Blood Cancer 2015; 62(4): 710-4.

40. Vaz L, Corneli A, Dulyx J, et al. The process of HIV status disclosure to HIV-positive youth in Kinshasa, Democratic Republic of the Congo. AIDS Care 2008; 20(7): 842-52.

41. Last BF, van Veldhuizen AM. Information about diagnosis and prognosis related to anxiety and depression in children with cancer aged 8-16 years. European Journal of Cancer 1996; 32A(2): 290-4.

42. Santamaria EK, Dolezal C, Marhefka SL, et al. Psychosocial implications of HIV serostatus disclosure to youth with perinatally acquired HIV. AIDS Patient Care STDS 2011; 25(4): 257-64.

43. Menon A, Glazebrook C, Campain N, Ngoma M. Mental health and disclosure of HIV status in Zambian adolescents with HIV infection: Implications for peer-support programs. Journal of Acquired Immune Deficiency Syndromes 2007; 46(3): 349-54.

44. Lester $\mathrm{P}$, Chesney $\mathrm{M}$, Cooke $\mathrm{M}$, et al. When the time comes to talk about HIV: factors associated with diagnostic disclosure and emotional distress in HIV-infected children. J Acquir Immune Defic Syndr 2002; 31(3): 309-17.

45. Kajubi P, Whyte SR, Kyaddondo D, Katahoire AR. Tensions in Communication between Children on Antiretroviral Therapy and Their Caregivers: A Qualitative Study in Jinja District, Uganda. PLOS ONE 2016; 11(1): e0147119. 
46. Cluver LD, Hodes RJ, Toska E, et al. 'HIV is like a tsotsi. ARVs are your guns': associations between HIV-disclosure and adherence to antiretroviral treatment among adolescents in South Africa. AIDS 2015; 29 Suppl 1: S57-65.

47. Mellins CA, Brackis-Cott E, Dolezal C, Richards A, Nicholas SW, Abrams EJ. Patterns of status disclosure to perinatally HIV-infected children and subsequent mental health outcomes. Clinical Child Psychology and Psychiatry 2002; 7(1): 101-14.

48. Blasini I, Chantry C, Cruz C, et al. Disclosure model for pediatric patients living with HIV in Puerto Rico: design, implementation, and evaluation. J Dev Behav Pediatr 2004; 25(3): 181-9.

49. Boon-Yasidhi V, Naiwatanakul T, Chokephaibulkit K, et al. Effect of HIV diagnosis disclosure on psychosocial outcomes in Thai children with perinatal HIV infection. Int J STD AIDS 2016; 27(4): 28895.

50. Fortier MA, Batista ML, Wahi A, Kain A, Strom S, Sender LS. Illness uncertainty and quality of life in children with cancer. J Pediatr Hematol Oncol 2013; 35(5): 366-70.

51. Butow P, Palmer S, Pai A, Goodenough B, Luckett T, King M. Review of adherence-related issues in adolescents and young adults with cancer. J Clin Oncol 2010; 28(32): 4800-9.

52. Spinetta JJ, Masera G, Eden T, et al. Refusal, non-compliance, and abandonment of treatment in children and adolescents with cancer: a report of the SIOP Working Committee on Phychosocial Issues in Pediatric Oncology. Med Pediatr Oncol 2002; 38(2): 114-7.

53. Haberer JE, Cook A, Walker AS, et al. Excellent adherence to antiretrovirals in HIV+ Zambian children is compromised by disrupted routine, HIV nondisclosure, and paradoxical income effects. PLOS ONE 2011; 6(4): e18505.

54. Fetzer BC, Mupenda B, Lusiama J, Kitetele F, Golin C, Behets F. Barriers to and facilitators of adherence to pediatric antiretroviral therapy in a Sub-Saharan setting: Insights from a qualitative study. AIDS Patient Care and STDs 2011; 25(10): 611-21.

55. Bikaako-Kajura W, Luyirika E, Purcell DW, et al. Disclosure of HIV status and adherence to daily drug regimens among HIV-infected children in Uganda. AIDS Behav 2006; 10(4 Suppl): S85-93.

56. Brown BJ, Oladokun RE, Osinusi K, Ochigbo S, Adewole IF, Kanki P. Disclosure of HIV status to infected children in a Nigerian HIV Care Programme. AIDS Care 2011; 23(9): 1053-8.

57. Abadia-Barrero CE, Larusso MD. The Disclosure Model versus a Developmental Illness Experience Model for Children and Adolescents Living with HIV/AIDS in Sao Paulo, Brazil. AIDS Patient Care and STDs 2006; 20(1): 36-43.

58. Vaz LM, Eng E, Maman S, Tshikandu T, Behets F. Telling children they have HIV: lessons learned from findings of a qualitative study in sub-Saharan Africa. AIDS Patient Care STDS 2010; 24(4): 247-56. 59. Marhefka SL, Turner DE, Chenneville T. HIV Disclosure in Paediatric Populations: Who, What, When to Tell, and then What? In: Chenneville T, ed. A Clinical Guide to Pediatric HIV: Springer International Publishing 2016: 189-227.

60. Ferris M, Burau K, Schweitzer AM, et al. The influence of disclosure of HIV diagnosis on time to disease progression in a cohort of Romanian children and teens. AIDS Care 2007; 19(9): 1088-94.

61. Sherman BF, Bonanno GA, Wiener LS, Battles HB. When children tell their friends they have AIDS: possible consequences for psychological well-being and disease progression. Psychosom Med 2000; 62(2): 238-47.

62. Kreicbergs U, Valdimarsdottir U, Onelov E, Henter JI, Steineck G. Talking about death with children who have severe malignant disease. N Engl J Med 2004; 351(12): 1175-86.

63. El Malla H, Kreicbergs U, Steineck G, Wilderang U, Elborai Yel S, Ylitalo N. Parental trust in health care--a prospective study from the Children's Cancer Hospital in Egypt. Psychooncology 2013; 22(3): 548-54.

64. Wolfe J, Klar N, Grier HE, et al. Understanding of prognosis among parents of children who died of cancer: impact on treatment goals and integration of palliative care. JAMA 2000; 284(19): 2469-75.

65. Wasserman AL, Thompson El, Wilimas JA, Fairclough DL. The psychological status of survivors of childhood/adolescent Hodgkin's disease. Am J Dis Child 1987; 141(6): 626-31. 
66. Fritz GK, Williams JR, Amylon M. After treatment ends: psychosocial sequelae in pediatric cancer survivors. Am J Orthopsychiatry 1988; 58(4): 552-61.

67. Gibson F, Aldiss S, Horstman M, Kumpunen S, Richardson A. Children and young people's experiences of cancer care: A qualitative research study using participatory methods. International Journal of Nursing Studies 2010; 47(11): 1397-407.

68. Aldridge J, Shimmon K, Miller M, Fraser LK, Wright B. 'I can't tell my child they are dying'. Helping parents have conversations with their child. Arch Dis Child Educ Pract Ed 2017; 102(4): 182-7. 69. Claflin CJ, Barbarin OA. Does "telling" less protect more? Relationships among age, information disclosure, and what children with cancer see and feel. Journal of Pediatric Psychology 1991; 16(2): 169-91.

70. Lorenz R, Grant E, Muyindike W, et al. Caregivers' Attitudes towards HIV Testing and Disclosure of HIV Status to At-Risk Children in Rural Uganda. PLoS ONE 2016; 11(2): e0148950.

71. Badarau DO, Wangmo T, Ruhe KM, et al. Parents' Challenges and Physicians' Tasks in Disclosing Cancer to Children. A Qualitative Interview Study and Reflections on Professional Duties in Pediatric Oncology. Pediatr Blood Cancer 2015; 62(12): 2177-82.

72. Clarke SA, Davies H, Jenney M, Glaser A, Eiser C. Parental communication and children's behaviour following diagnosis of childhood leukaemia. Psychooncology 2005; 14(4): 274-81.

73. Zwaanswijk M, Tates K, van Dulmen S, et al. Communicating with child patients in pediatric oncology consultations: a vignette study on child patients', parents', and survivors' communication preferences. Psychooncology 2011; 20(3): 269-77.

74. Vaz LM, Maman S, Eng E, Barbarin OA, Tshikandu T, Behets F. Patterns of disclosure of HIV status to infected children in a Sub-Saharan African setting. J Dev Behav Pediatr 2011; 32(4): 307-15.

75. Young B, Ward J, Salmon P, Gravenhorst K, Hill J, Eden T. Parents' experiences of their children's presence in discussions with physicians about Leukemia. Pediatrics 2011; 127(5): e1230-8.

76. Young B, Dixon-Woods M, Windridge KC, Heney D. Managing communication with young people who have a potentially life threatening chronic illness: qualitative study of patients and parents. BMJ 2003; 326(7384): 305-8.

77. Coyne I, Amory A, Gibson F, Kiernan G. Information-sharing between healthcare professionals, parents and children with cancer: more than a matter of information exchange. Eur $J$ Cancer Care (Engl) 2016; 25(1): 141-56.

78. Biadgilign S, Deribew A, Amberbir A, Escudero HR, Deribe K. Factors associated with HIV/AIDS diagnostic disclosure to HIV infected children receiving HAART: a multi-center study in Addis Ababa, Ethiopia. PLOS ONE 2011; 6(3): e17572.

79. Oberdorfer P, Puthanakit T, Louthrenoo O, Charnsil C, Sirisanthana V, Sirisanthana T. Disclosure of HIV/AIDS diagnosis to HIV-infected children in Thailand. J Paediatr Child Health 2006; 42(5): 283-8.

80. Wiener LS, Battles HB, Heilman N, Sigelman CK, Pizzo PA. Factors associated with disclosure of diagnosis to children with HIV/AIDS. Pediatr AIDS HIV Infect 1996; 7(5): 310-24.

81. Rodriguez EM, Dunn MJ, Zuckerman T, et al. Mother-child communication and maternal depressive symptoms in families of children with cancer: integrating macro and micro levels of analysis. Journal of Pediatric Psychology 2013; 38(7): 732-43.

82. Goldman A, Christie D. Children with cancer talk about their own death with their families. Pediatr Hematol Oncol 1993; 10(3): 223-31.

83. Sisk BA, Mack JW, Ashworth R, DuBois J. Communication in pediatric oncology: State of the field and research agenda. Pediatr Blood Cancer 2018; 65(1): e26727.

84. Kearney MK, Weininger RB, Vachon ML, Harrison RL, Mount BM. Self-care of physicians caring for patients at the end of life: "Being connected... a key to my survival". JAMA 2009; 301(11): 115564, E1.

85. Woolley $\mathrm{H}$, Stein A, Forrest GC, Baum JD. Staff stress and job satisfaction at a children's hospice. Arch Dis Child 1989; 64(1): 114-8. 
86. Rotenstein LS, Ramos MA, Torre M, et al. Prevalence of Depression, Depressive Symptoms, and Suicidal Ideation Among Medical Students: A Systematic Review and Meta-Analysis. JAMA 2016; 316(21): 2214-36.

87. Binger $\mathrm{CM}$, Ablin AR, Feuerstein RC, Kushner JH, Zoger S, Mikkelsen C. Childhood leukemia. Emotional impact on patient and family. N Engl J Med 1969; 280(8): 414-8.

88. Sahler OJ, Frager G, Levetown M, Cohn FG, Lipson MA. Medical education about end-of-life care in the pediatric setting: principles, challenges, and opportunities. Pediatrics 2000; 105(3 Pt 1): $575-84$.

89. Amery J, Downing J, Cunningham C. In: Amery J, ed. Children's Palliative Care in Africa. New York, USA: Oxford Univeristy Press; 2009: 289-304.

90. Beima-Sofie K, John-Stewart G, Shah B, Wamalwa D, Maleche-Obimbo E, Kelley M. Using health provider insights to inform pediatric HIV disclosure: a qualitative study and practice framework from Kenya. AIDS Patient Care STDS 2014; 28(10): 555-64.

91. Vreeman RC, Scanlon ML, Inui TS, et al. 'Why did you not tell me?': perspectives of caregivers and children on the social environment surrounding child HIV disclosure in Kenya. AIDS 2015; 29 SuppI 1: S47-55.

92. Bates AT, Kearney JA. Understanding death with limited experience in life: dying children's and adolescents' understanding of their own terminal illness and death. Curr opin support palliat care 2015; 9(1): 40-5.

93. Zwaanswijk M, Tates K, van Dulmen S, Hoogerbrugge PM, Kamps WA, Bensing JM. Young patients', parents', and survivors' communication preferences in paediatric oncology: results of online focus groups. BMC Pediatr 2007; 7(35): 1-10.

94. Dunsmore J, Quine S. Information, support, and decision-making needs and preferences of adolescents with cancer: Implications for health professionals. Journal of Psychosocial Oncology 1995; 13(4): 35-56.

95. Woolley $\mathrm{H}$, Stein A, Forrest GC, Baum JD. Imparting the diagnosis of life threatening illness in children. BMJ 1989; 298(6688): 1623-6.

96. Levenson PM, Pfefferbaum BJ, Copeland DR, Silberberg Y. Information preferences of cancer patients ages 11-20 years. J Adolesc Health Care 1982; 3(1): 9-13.

97. Roscigno $\mathrm{Cl}$, Grant G, Savage TA, Philipsen G. Parent perceptions of early prognostic encounters following children's severe traumatic brain injury: 'locked up in this cage of absolute horror'. Brain Inj 2013; 27(13-14): 1536-48.

98. Mack JW, Wolfe J, Grier HE, Cleary PD, Weeks JC. Communication about prognosis between parents and physicians of children with cancer: parent preferences and the impact of prognostic information. J Clin Oncol 2006; 24(33): 5265-70.

99. Myer L, Moodley K, Hendricks F, Cotton M. Healthcare providers' perspectives on discussing HIV status with infected children. J Trop Pediatr 2006; 52(4): 293-5.

100. Arun S, Singh AK, Lodha R, Kabra SK. Disclosure of the HIV infection status in children. Indian J Pediatr 2009; 76(8): 805-8.

101. Merzel C, VanDevanter N, Irvine M. Adherence to antiretroviral therapy among older children and adolescents with HIV: A qualitative study of psychosocial contexts. AIDS Patient Care and STDs 2008; 22(12): 977-87.

102. Moodley K, Myer L, Michaels D, Cotton M. Paediatric HIV disclosure in South Africa -caregivers' perspectives on discussing HIV with infected children. S Afr Med J 2006; 96(3): 201-4.

103. Caldwell PH, Murphy SB, Butow PN, Craig JC. Clinical trials in children. Lancet 2004; 364(9436): 803-11.

104. UNICEF. Convention on the Rights of the Child. 1989.

105. Hynson JL, Aroni R, Bauld C, Sawyer SM. Research with bereaved parents: a question of how not why. Palliat Med 2006; 20(8): 805-11. 
106. Masera G, Chesler MA, Jankovic M, et al. SIOP Working Committee on psychosocial issues in pediatric oncology: guidelines for communication of the diagnosis. Med Pediatr Oncol 1997; 28(5): 382-5. 